\title{
Schroeteria Decaisneana, S. Poeltii, and Ciboria Ploettneriana (Sclerotiniaceae, Helotiales, Ascomycota), Three Parasites on Veronica Seeds: First Report of Teleomorphs in Schroeteria
}

\author{
Hans-Otto Baral ( $\sim$ zotto@arcor.de ) \\ Tübingen, Germany \\ Peter Rönsch \\ private \\ Udo Richter \\ private \\ Alexander Urban \\ University of Vienna: Universitat Wien \\ Julia Kruse \\ Pfalzmuseum für Naturkunde \\ Martin Bemmann \\ private \\ Volker Kummer \\ University of Potsdam \\ Francisco Javier Valencia \\ private \\ Wolfgang Huth \\ private
}

\section{Research Article}

Keywords: anamorph-teleomorph connection, plant parasite, false smut fungi, seed infection, Veronica hederifolia, Veronica cymbalaria

Posted Date: June 11th, 2021

DOI: https://doi.org/10.21203/rs.3.rs-578062/v1

License: (c) (i) This work is licensed under a Creative Commons Attribution 4.0 International License. Read Full License

Version of Record: A version of this preprint was published at Mycological Progress on January 1st, 2022. See the published version at https://doi.org/10.1007/s11557-021-01742-4. 


\section{Abstract}

Three little known, morphologically similar species of Sclerotiniaceae which form their apothecia on fallen stromatized Veronica seeds are described and illustrated in detail based on fresh collections or moist chamber cultures of infected seeds: Ciboria ploettneriana,

Schroeteria decaisneana, and Schroeteria poeltii. The former two were found on Veronica hederifolia agg. at different sites of temperate central Europe, the latter on $V$. cymbalaria in a mediterranean region of Spain. The latter two are anamorph-typified and here reported for the first time with their teleomorph.

Ciboria ploettneriana was described by Kirschstein as Sclerotiniaploettneriana on seeds of $V$. hederifolia agg. but is currently treated in Ciboria. Based on the reexamination of four syntype specimens in B it became evident that Kirschstein confused the two species on $V$. hederifolia. A lectotype is therefore designated for S. ploettneriana.

Members of Schroeteria are specific plant parasites infecting fruits of different Veronica spp. Schroeteria has earlier been referred to the Ustilaginales (Basidiomycota) based on its smut-like chlamydospores, but later light-microscopic and ultrastructural studies suggested that it represents a false smut fungus belonging to the Sclerotiniaceae (Helotiales).

rDNA sequences were obtained from chlamydospores of Schroeteria bornmuelleri (on V. rubrifolia), S. delastrina (generic type, on Veronica arvensis), S. decaisneana, and S. poeltii, and from apothecia on $V$. hederifolia agg. and $V$. cymbalaria seeds. As a result, the anamorphteleomorph connection could be verified for Schroeteria decaisneana and S. poeltii based on a $100 \%$ ITS similarity between both morphs, whereas Ciboria ploettneriana in the here redefined sense could not be connected to an anamorph.

Our phylogenetic analyses show that Ciboria ploettneriana belongs in the relationship of Sclerotinia, Stromatinia, and Grovesinia rather than Ciboria, but its placement was not supported. Also Schroeteria poeltii clustered unresolved in this relationship but has a much higher molecular distance to those. The remaining three Schroeteria spp. formed a supported monophyletic group, the Schroeteria core clade, which clustered with medium to low support distantly to a member of the Monilinia alpina group of section Disjunctoriae (M. jezoensis). ITS distances of 5-6.3\% were found among members of the Schroeteria core clade, and $13.8-14.7 \%$ between the core clade and $S$. poeltii. The high distance of $S$. poeltii reflects its deviating chlamydospore morphology.

Despite the high heterogeneity in the available ITS and LSU data, Schroeteria is accepted here under inclusion of $S$. poeltii as a genus distinct from Monilinia, particularly because of its very special anamorphs. A similar heterogeneity in rDNA analyses was observed in Monilinia and other genera of Sclerotiniaceae. Protein-coding genes should be investigated in order to obtain a more natural phylogeny within the Sclerotiniaceae.

\section{Introduction}

The family Sclerotiniaceae comprises about 150 mainly plant parasitic species in 28 accepted genera (Baral 2016). Most of these genera are pleomorphic, producing apothecia (teleomorph, sexual) and a conidial state (anamorph, asexual), but some are still without a known teleomorph. Sclerotiniaceae are thought to be a relatively recently evolved lineage of primarily necrotrophic but often biotrophic (parasitic) host generalists or specialists (Andrew et al. 2012). Species of the family are generally hygrobionts, i.e., they form their apothecia and conidial states on fallen, permanently moist remnants of various mono- and dicotyledonous plants: on herbaceous stems, leaves, flowers, fruits and seeds, also on wood and bark, rarely on dung (Whetzel 1945, Schumacher \& Kohn 1985, Spooner 1987, Palmer 1991, Baral 2016). Three xerobiotic, apparently necrotrophic species on air-exposed branches, previously included in the heterogeneous subfamily Encoelioideae of Helotiaceae, have recently been transferred to Sclerotiniaceae and placed in the new genus Sclerencoelia Pärtel \& Baral (Pärtel et al. 2016), which raises the number of accepted genera to 29.

A main characteristic of the Sclerotiniaceae and the closely related, paraphyletic, necrotrophic to parasitic Rutstroemiaceae is the amyloid ascus apical ring of the Sclerotinia-type (Baral 1987, Verkley 1993). Members of both families have usually brownish coloured apothecia, and their stipe base is often blackish. Apothecia of Sclerotiniaceae emerge from a black sclerotium (sclerotial stroma) or, similar as in Rutstroemiaceae, from stromatized host tissue (substratal stroma). Species of Sclerencoelia deviate from the remaining genera of the family in persistent, drought-tolerant apothecia and in asci with a more or less reduced apical ring. Sclerotiniaceae generally have at their

flanks of the receptacle an ectal excipulum of textura globulosa which often includes rhomboid crystals, whereas Rutstroemiaceae mostly have a textura prismatica without crystals (Baral 2016).

Hyphomycetous or sometimes sporodochial, acervular, or pycnidial anamorphs are typical of the family (for references see Baral 2016). Various members form characteristic macroconidial anamorphs, the most familiar being Botrytis P. Micheli ex Pers. and Monilia Bonord., 
which are important plant pathogens and also known for their teleomorph-typified names Botryotinia Whetzel and Monilinia Honey. Most members of Sclerotiniaceae possess phialidic microconidial synanamorphs which are either formed directly from ascospores or on short germ tubes (Schumacher \& Kohn 1985).

The genus Schroeteria G. Winter, a group of false smut fungi, which over a long time has been misplaced in Ustilaginales (now Ustilaginomycetes), is extraordinary in forming sori of pigmented mitosporic diaspores, which are classified as chlamydospores, in fruits of different Veronica spp. They form a powdery spore mass which at maturity often completely fills the capsules of their host. The chlamydospores are roundish, warted, somewhat thick-walled, and show light yellowish- to reddish- or greyish-brown colours under transmitted light.but appear macroscopically dark brown to blackish. Schroeteria also possesses a phialidic microconidial synanamorph that develops on the chlamydospores, for which it was assumed to represent a member of Sclerotiniaceae (Brefeld 1883, 1912, Vánky 1982, Nagler et al. 1989). The mycelium of Schroeteria spp. destroys the interior (seeds and/or funiculi and placenta) of the capsules of living plants without forming a dark stroma.

During 1986-2019, two morphologically similar sclerotiniaceous discomycetes have been collected on fallen previous year's seeds of Veronica hederifolia agg. (ivy-leaved speedwell) at different sites of central Europe. In the first collection made in 1986 by P. Blank near Schaffhausen (Switzerland), the substrate was misinterpreted as gall of a gall wasp, therefore, the species was compared with gallinhabiting Sclerotiniaceae (Baral 1986, Palmer 1991). Further collections were made in 2003-2004 by G. Hensel, M., W. \& E. Huth, and P. Rönsch in Sachsen-Anhalt (Germany), during which the substrate was correctly identified as Veronica seeds, owing to

At that time it became evident that one of the two discomycetes must be Ciboria ploettneriana (Kirschst. in Rehm) N.F. Buchw. This rarely reported species was described by Kirschstein (1906) on seeds of $V$. hederifolia agg. from collections made in 1899 and 1905 near Brandenburg a. d. Havel, and distributed by him in Ascom. exsicc. (Rehm 1905). Only a few later reports under this name are known to us (all from Germany): Benkert (2005) presented a sample made in 1992 in Berlin-Baumschulenweg, Kreisel (2011) published another sample made in 2008 by D. Benkert in the park of castle Liebenberg in Brandenburg, and Huth (2009: 103, pl. 36 fig. 104) reported three samples made by G. Hensel, M. \& W. Huth, and P. Rönsch in April-May 2003-2004 near Merseburg and Freyburg in Sachsen-Anhalt.

In 2019 we started our bibliographic and molecular investigations on the genus Schroeteria, based on M. Bemmann's suspicion that this genus could represent the anamorph of the two discomycetes. In fact, chlamydospores of S.decaisneana (Boud.) De Toni could subsequently be detected in May 2019 by H. \& U. Richter at the Zeuchfeld site on mature non-stromatized seeds in the capsules of living plants. As a result from rDNA sequences obtained by A. Urban and J. Kruse, Ciboria ploettneriana is closely related to Sclerotinia but not to Schroeteria, whereas the other discomycete on V. hederifolia agg. is conspecific with Schroeteria decaisneana. Apothecia of a third species, which was detected by F.J. Valencia in January 2017 on seeds of V.cymbalaria in a mediterranean area of southern Spain and which morphologically only slightly differs from $S$. decaisneana, turned out to belong to S. poeltii Vánky. Accordingly, we here adopt Schroeteria as the correct name for the holomorphs of $S$. decaisneana and S. poeltii, and retain the name Ciboria ploettneriana for the time being.

Usually, apothecia of each of the two species on $V$. hederifolia agg. were collected at different sites in Sachsen-Anhalt, but at one of these sites (Zeuchfeld near Freyburg) both species occurred sympatric in the same habitat, though in different months. Their growth on the same substrate at the same site could speak for some kind of hyperparasitism, based on comparable hypotheses which have earlier been proposed in other genera of Sclerotiniaceae, in which two different species emerge from sclerotia formed on the same host plant, but any observations that would support this hypothesis are lacking.

\section{Materials And Methods}

Used abbreviations: LBs = KOH-inert oil drops (lipid bodies); VBs = KOH-sensitive refractive vacuolar bodies; $\mathrm{SCBs}=\mathrm{KOH}$-sensitive cytoplasmic bodies; $\mathrm{OCl}=$ relative oil content index $(0=$ without oil drops, $5=$ maximum lipid content $)$; $=$ observation of living cells, $\dagger=$ observation of dead cells; MTB = Messtischblatt (German topographic map), IVV = www.in-vivo-veritas.de (link to drawings and photographs); sin. doc. $=$ without macro- or microscopic documentation, $\varnothing=$ unpreserved, sq. $=$ sequence in GenBank .

Pure cultures from ascospores were tried on MEA (Malt Extract Agar) and MMN (Modified Melin Norkrans Medium) (A.U.). In order to induce the formation of microconidia from ascospores, apothecia were placed for $3-4$ days in a moist chamber at $10-20^{\circ} \mathrm{C}$. The formation of apothecia from seeds was achieved by picking up infected, blackened seeds in June and placing them at the same day in a garden. 
Veronica species were identified using Jäger (2017) and Parolly \& Rohwer (2019), for V. cymbalaria Jahn \& Schönfelder (1995), and for V. campylopoda Hong \& Fischer (1998). Current plant names were established using The Plant List (2020).

Molecular methods. Sequences of ITS and LSU rDNA were obtained by A. Urban from apothecia of two samples of Schroeteria decaisneana (Zeuchfeld near Freyburg, Germany) and one of Ciboria ploettneriana (Alte Göhle near Freyburg). Further sequences of ITS and LSU rDNA were obtained by J. Kruse and S. Ploch from anamorph sori of Schroeteria decaisneana (Zeuchfeld, Sachsen-Anhalt), $S$. delastrina (Tul. \& C. Tul.) G. Winter (Kyffhäuser and Hainleite, Thüringen), S. bornmuelleri P. Magnus (Mahhad, Iran), and S. poeltii Vánky (Rhodos, Greece), and from apothecia of $S$. poeltii (Ronda, Spain). These sequences comprise the entire ITS region and the LSU D1-D2 domain. Three of the sori extracts were $2-3 \times$ sequenced. For verifying the macroscopically identified $V$. cymbalaria the plant ITS was sequenced.

Methods used by J. Kruse and S. Ploch: About 2-10 mg of spore mass was taken from infected seeds of the fungarium samples J.K. S1346 (GLM-F129032), S1304, B2278, V. K. P1652-23, -26, -27, H.U.V. 750 ex TUB and C.V.L.040117 (GLM-F29000). The material was placed in $2 \mathrm{~mL}$ plastic reaction tubes and homogenized in a mixer mill (MM2, Retsch) using a combination of five to eight $1 \mathrm{~mm}$ and three $3 \mathrm{~mm}$ metal beads at $25 \mathrm{~Hz}$ for $5 \mathrm{~min}$. Genomic DNA was extracted using the E.Z.N.A Plant DNA Mini Kit (VWR). The incubation time was extended to one hour. The complete nrITS of all DNA extracts were amplified using the primer pair ITS1F and ITS4 (White et al. 1990, Gardes \& Bruns 1993) at $56{ }^{\circ} \mathrm{C}$ annealing temperature. The cycling reaction was performed in a thermocycler (Eppendorf Mastercycler 96 vapo protect; Eppendorf, Hamburg) with an initial denaturation at $95^{\circ} \mathrm{C}$ for $4 \mathrm{~min}, 36 \mathrm{PCR}$ cycles of denaturation at $95^{\circ} \mathrm{C}$ for $40 \mathrm{~s}$, annealing at $56^{\circ} \mathrm{C}$ for $40 \mathrm{~s}$ and elongation at $72{ }^{\circ} \mathrm{C}$ for $60 \mathrm{~s}$, followed by a final elongation at $72{ }^{\circ} \mathrm{C}$ for 4 min. The LSU rDNA was amplified using the primer pair LROR and LR5 (Vilgalys 1988) with the condition mentioned in Vilgalys \& Hester (1990). The resulting amplicons were sequenced at the Biodiversity and Climate Research Centre (BiK-F) laboratory using the abovementioned PCR primers. Sequences were deposited in GenBank (https://www.ncbi.nlm.nih.gov/genbank/, Tab. 1).

Alignments were done with MAFFT (https://mafft.cbrc.jp/alignment/server/). Maximum likelihood phylogenetic analyses were carried out with MEGA7 and MEGAX with the settings 'use all sites, nearest-neighbour-interchange, weak branch swap filter', also with IQ-tree. Branch support is given as maximum likelihood bootstrap percentages. P-distances were evaluated with MEGA6 and MEGA7 using individual alignments of species pairs. ana = anamorph, tel = teleomorph.

Table 1. Sequences included in phylogenetic analyses (new sequences in bold; tel = teleomorph, ana = anamorph, $T=$ from type). 


\begin{tabular}{|c|c|c|c|c|c|c|}
\hline Species & $\begin{array}{l}\text { Collection } \\
\text { number }\end{array}$ & Country & Host & ITS & LSU & Reference \\
\hline Botrytis cinerea & CBS 179.71 & Netherlands & $\begin{array}{l}\text { Cichorium } \\
\text { endivia }\end{array}$ & MH860054 & MH871836 & $\begin{array}{l}\text { Vu et al. } \\
2019\end{array}$ \\
\hline Botrytis porri tel & WU 43987 & Germany & $\begin{array}{l}\text { Allium } \\
\text { scorodoprasum }\end{array}$ & MZ048347 & MZ048347 & This study \\
\hline $\begin{array}{l}\text { Cenangium } \\
\text { acuum }\end{array}$ & $\begin{array}{l}\text { H.B. } 9325 b \text {, } \\
\text { TAAM:198515 }\end{array}$ & Germany & Pinus sylvestris & LT158439 & KX090822 & $\begin{array}{l}\text { Pärtel et al. } \\
2016\end{array}$ \\
\hline $\begin{array}{l}\text { Cenangium } \\
\text { ferruginosum }\end{array}$ & $\begin{array}{l}\text { G.M. 2015-08- } \\
15.1\end{array}$ & Luxembourg & Pinus & KY462796 & KY462796 & $\begin{array}{l}\text { G. Marson } \\
\text { unpubl. }\end{array}$ \\
\hline $\begin{array}{l}\text { Chlorociboria } \\
\text { aeruginosa }\end{array}$ & UBC F19715 & Canada & indet. wood & HQ604856 & HQ604856 & $\begin{array}{l}\text { M.L. Berbee } \\
\text { et al. } \\
\text { unpubl. }\end{array}$ \\
\hline $\begin{array}{l}\text { Ciboria } \\
\text { amentacea }\end{array}$ & A.U. 2760 & Austria & Alnus glutinosa & KT970066 & KT970066 & $\begin{array}{l}\text { Baral \& } \\
\text { Haelewaters } \\
2015\end{array}$ \\
\hline $\begin{array}{l}\text { Ciboria } \\
\text { americana }\end{array}$ & CBS 117.24 & $?$ & $\begin{array}{l}\text { Castanea } \\
\text { sativa }\end{array}$ & MH854767 & MH866271 & $\begin{array}{l}\text { Vu et al. } \\
2019\end{array}$ \\
\hline $\begin{array}{l}\text { Ciboria } \\
\text { asphodeli }\end{array}$ & F142282 & Spain & $\begin{array}{l}\text { Asphodelus } \\
\text { fistulosus }\end{array}$ & KJ941085 & KJ941065 & $\begin{array}{l}\text { Checa et al. } \\
\text { (Bicorn.) }\end{array}$ \\
\hline $\begin{array}{l}\text { Ciboria } \\
\text { batschiana }\end{array}$ & TNS:F-44241 & Japan & $?$ & AB926056 & AB926143 & $\begin{array}{l}\text { T. Hosoya et } \\
\text { al. unpubl. }\end{array}$ \\
\hline Ciboria betulae & 1145.P & Norway & Betula & Z81427 & Z81403 & $\begin{array}{l}\text { Holst } \\
\text { Jensen et } \\
\text { al. 1997b }\end{array}$ \\
\hline $\begin{array}{l}\text { Ciboria } \\
\text { carunculoides }\end{array}$ & $\mathrm{ms} 94$ & China & Morus & HQ833459 & - & $\begin{array}{l}\text { Hu et al. } \\
2011\end{array}$ \\
\hline Ciboria caucus & 1572.1 & Norway & Salix caprea & Z73766 & Z73740 & $\begin{array}{l}\text { Holst } \\
\text { Jensen et } \\
\text { al. 1997b }\end{array}$ \\
\hline $\begin{array}{l}\text { Ciboria } \\
\text { conformata }\end{array}$ & F145906 & Spain & Alnus glutinosa & KJ941075 & KJ941057 & $\begin{array}{l}\text { Galán et al. } \\
(2015)\end{array}$ \\
\hline $\begin{array}{l}\text { Ciboria aff. } \\
\text { conformata }\end{array}$ & $\begin{array}{l}\text { KL102, } \\
\text { TAAM:137925 }\end{array}$ & Greenland & Salix glauca & LT158414 & - & $\begin{array}{l}\text { Pärtel et al. } \\
2016\end{array}$ \\
\hline Ciboria coryli tel & WU 31551 & Austria & $\begin{array}{l}\text { Corylus } \\
\text { avellana }\end{array}$ & $X X X X X X X$ & $X X X X X X X$ & This study \\
\hline $\begin{array}{l}\text { Ciboria } \\
\text { shiraiana }\end{array}$ & KUS-F52447 & Korea & Morus australis & JN033430 & JN086733 & $\begin{array}{l}\text { Han et al. } \\
2014\end{array}$ \\
\hline $\begin{array}{l}\text { Ciboria } \\
\text { shiraiana }\end{array}$ & $\mathrm{ms} 93$ & China & Morus & HQ833458 & - & $\begin{array}{l}\text { Hu et al. } \\
2011\end{array}$ \\
\hline $\begin{array}{l}\text { Ciboria } \\
\text { viridifusca }\end{array}$ & $\begin{array}{l}\text { KL212, } \\
\text { TAAM:165962 }\end{array}$ & Estonia & Alnus & LT158429 & KX090812 & $\begin{array}{l}\text { Pärtel et al. } \\
2016\end{array}$ \\
\hline $\begin{array}{l}\text { Ciborinia } \\
\text { erythronii }\end{array}$ & CBS $300.31 \mathrm{~T}$ & USA & $\begin{array}{l}\text { Erythronium } \\
\text { americanum }\end{array}$ & MH855221 & MH866671 & $\begin{array}{l}\text { Vu et al. } \\
2019\end{array}$ \\
\hline $\begin{array}{l}\text { Ciborinia } \\
\text { erythronii }\end{array}$ & 1838.P & Canada & Erythronium sp. & Z73767 & Z73741 & $\begin{array}{l}\text { Holst } \\
\text { Jensen et } \\
\text { al. 1997b }\end{array}$ \\
\hline $\begin{array}{l}\text { Ciborinia } \\
\text { foliicola }\end{array}$ & 1932.H & Canada & Salix & Z80892 & Z81404 & $\begin{array}{l}\text { Holst } \\
\text { Jensen et } \\
\text { al. 1997b }\end{array}$ \\
\hline $\begin{array}{l}\text { Ciborinia } \\
\text { gentianae }\end{array}$ & JCM 13253 T & Japan & $\begin{array}{l}\text { Gentiana trifl. } \\
\text { var. japon. }\end{array}$ & LC228669 & LC228727 & $\begin{array}{l}\text { G. Okada et } \\
\text { al. unpubl. }\end{array}$ \\
\hline $\begin{array}{l}\text { Ciborinia } \\
\text { whetzelii }\end{array}$ & 1927.H & Canada & $\begin{array}{l}\text { Populus } \\
\text { tremuloides }\end{array}$ & Z73768 & Z73742 & $\begin{array}{l}\text { Holst } \\
\text { Jensen et }\end{array}$ \\
\hline
\end{tabular}

Page 5/55 
al. 1997b

\begin{tabular}{|c|c|c|c|c|c|c|}
\hline $\begin{array}{l}\text { Coprotinia } \\
\text { minutula }\end{array}$ & 1916.P & Canada & $\begin{array}{l}\text { Coleoptera } \\
\text { dung }\end{array}$ & Z81428 & Z81405 & $\begin{array}{l}\text { Holst } \\
\text { Jensen et } \\
\text { al. 1997b }\end{array}$ \\
\hline $\begin{array}{l}\text { Cristulariella } \\
\text { depraedans }\end{array}$ & KUS-F25920 & Korea & Acer ginnala & KT462571 & KX098505 & $\begin{array}{l}\text { Cho et al. } \\
2017\end{array}$ \\
\hline $\begin{array}{l}\text { Dumontinia } \\
\text { tuberosa tel }\end{array}$ & $\begin{array}{l}\text { B.S.I. 10/20, WU } \\
43990\end{array}$ & Switzerland & $\begin{array}{l}\text { Anemone } \\
\text { nemorosa }\end{array}$ & MZ048350 & MZ048350 & This study \\
\hline Elliottinia kerneri & $\begin{array}{l}\text { KL402, } \\
\text { TU:104529 }\end{array}$ & Switzerland & Abies alba & LT158475 & LT158475 & $\begin{array}{l}\text { Pärtel et al. } \\
2016\end{array}$ \\
\hline $\begin{array}{l}\text { Gloeotinia } \\
\text { granigena }\end{array}$ & 1931.S & ?Norway & Elymus repens & Z81432 & Z81408 & $\begin{array}{l}\text { Holst } \\
\text { Jensen et } \\
\text { al. 1997b }\end{array}$ \\
\hline $\begin{array}{l}\text { Grovesinia } \\
\text { moricola }\end{array}$ & KUS-F26901 & Korea & $\begin{array}{l}\text { Humulus } \\
\text { scandens }\end{array}$ & KC460209 & KX098504 & $\begin{array}{l}\text { Cho et al. } \\
2013\end{array}$ \\
\hline $\begin{array}{l}\text { Grovesinia } \\
\text { moricola }\end{array}$ & 1836.K, LMK38 & USA & Juglans nigra & Z81433 & Z81409/AJ226081 & $\begin{array}{l}\text { Holst } \\
\text { Jensen et } \\
\text { al. 1997b }\end{array}$ \\
\hline $\begin{array}{l}\text { Haradamyces } \\
\text { foliicola }\end{array}$ & MAFF $411026 \mathrm{~T}$ & Japan & Cornus florida & AB329720 & - & $\begin{array}{l}\text { Masuya et } \\
\text { al. } 2009\end{array}$ \\
\hline $\begin{array}{l}\text { Hymenoscyphus } \\
\text { scutula }\end{array}$ & $\begin{array}{l}\text { G.M. 2014-12- } \\
25.2\end{array}$ & Luxembourg & indet. herb & MK674606 & MK674606 & $\begin{array}{l}\text { G. Marson } \\
\text { unpubl. }\end{array}$ \\
\hline $\begin{array}{l}\text { Kohninia } \\
\text { linnaeicola }\end{array}$ & 3200.H T? & Norway & $\begin{array}{l}\text { Linnaea } \\
\text { borealis }\end{array}$ & AY236422 & - & $\begin{array}{l}\text { Holst } \\
\text { Jensen et } \\
\text { al. 1997b }\end{array}$ \\
\hline $\begin{array}{l}\text { Lambertella } \\
\text { corni-maris }\end{array}$ & CLX4075 & USA & Malus & KC958562 & KC964858 & $\begin{array}{l}\text { Wiseman et } \\
\text { al. } 2015\end{array}$ \\
\hline $\begin{array}{l}\text { Lambertella } \\
\text { pyrolae }\end{array}$ & TNS-F 40132 T & Japan & $\begin{array}{l}\text { Pyrola } \\
\text { incarnata }\end{array}$ & AB926081 & AB926164 & $\begin{array}{l}\text { T. Hosoya et } \\
\text { al. unpubl. }\end{array}$ \\
\hline $\begin{array}{l}\text { Martininia } \\
\text { panamaensis }\end{array}$ & $\begin{array}{l}\text { CBS } 358.72, \text { CUP } \\
50076\end{array}$ & France & indet. wood & MH860497 & MH872212 & $\begin{array}{l}\text { Vu et al. } \\
2019\end{array}$ \\
\hline $\begin{array}{l}\text { Monilinia } \\
\text { amelanchieris }\end{array}$ & 1918.K & USA & $\begin{array}{l}\text { Amelanchier } \\
\text { canadensis }\end{array}$ & Z73769 & Z73743 & $\begin{array}{l}\text { Holst } \\
\text { Jensen et } \\
\text { al. 1997b }\end{array}$ \\
\hline $\begin{array}{l}\text { Monilinia } \\
\text { aucupariae }\end{array}$ & 885.2 & Norway & $\begin{array}{l}\text { Sorbus } \\
\text { aucuparia }\end{array}$ & Z73771 & Z73744 & $\begin{array}{l}\text { Holst } \\
\text { Jensen et } \\
\text { al. 1997b }\end{array}$ \\
\hline $\begin{array}{l}\text { Monilinia } \\
\text { azaleae }\end{array}$ & $\begin{array}{l}\text { 1939.S, } \\
\text { ATCC58539 }\end{array}$ & USA & $\begin{array}{l}\text { Rhododendron } \\
\text { roseum }\end{array}$ & AB182266 & Z73745 & $\begin{array}{l}\text { Holst } \\
\text { Jensen et } \\
\text { al. 1997b }\end{array}$ \\
\hline $\begin{array}{l}\text { Monilinia } \\
\text { baccarum }\end{array}$ & 951.2 & Norway & $\begin{array}{l}\text { Vaccinium } \\
\text { myrtillus }\end{array}$ & Z73773 & Z73746 & $\begin{array}{l}\text { Holst } \\
\text { Jensen et } \\
\text { al. 1997b }\end{array}$ \\
\hline $\begin{array}{l}\text { Monilinia } \\
\text { cassiopes }\end{array}$ & 1459.S & Norway & $\begin{array}{l}\text { Cassiope } \\
\text { tetragona }\end{array}$ & Z73776 & Z73747 & $\begin{array}{l}\text { Holst } \\
\text { Jensen et } \\
\text { al. 1997b }\end{array}$ \\
\hline $\begin{array}{l}\text { Monilinia } \\
\text { fructicola }\end{array}$ & CBS 127259 & Australia & Prunus persica & MH864497 & MH875934 & $\begin{array}{l}\text { Vu et al. } \\
2019\end{array}$ \\
\hline $\begin{array}{l}\text { Monilinia } \\
\text { fructicola }\end{array}$ & 782.K & Canada & Prunus persica & Z73777 & Z73748 & $\begin{array}{l}\text { Holst } \\
\text { Jensen et } \\
\text { al. 1997b }\end{array}$ \\
\hline $\begin{array}{l}\text { Monilinia } \\
\text { fructigena }\end{array}$ & CBS 493.50 & Netherlands & $\begin{array}{l}\text { Malus } \\
\text { sylvestris }\end{array}$ & MH856721 & MH868240 & $\begin{array}{l}\text { Vu et al. } \\
2019\end{array}$ \\
\hline $\begin{array}{l}\text { Monilinia } \\
\text { gaylussaciae }\end{array}$ & $\begin{array}{l}\text { 1919.P ATCC } \\
64508\end{array}$ & USA & $\begin{array}{l}\text { Gaylussacia } \\
\text { baccata }\end{array}$ & Z73782 & Z73750 & $\begin{array}{l}\text { Holst } \\
\text { Jensen et }\end{array}$ \\
\hline
\end{tabular}


al. $1997 b$

\begin{tabular}{|c|c|c|c|c|c|c|}
\hline $\begin{array}{l}\text { Monilinia } \\
\text { jezoensis }\end{array}$ & $4222 \mathrm{~T}$ & Japan & $\begin{array}{l}\text { Rhododendron } \\
\text { kaempferi }\end{array}$ & AB182265 & - & $\begin{array}{l}\text { Takahashi } \\
\text { et al. } 2005\end{array}$ \\
\hline $\begin{array}{l}\text { Monilinia } \\
\text { johnsonii }\end{array}$ & 1920.K & USA & Crataegus & Z73783 & Z73751 & $\begin{array}{l}\text { Holst } \\
\text { Jensen et } \\
\text { al. 1997b }\end{array}$ \\
\hline Monilinia laxa & 2013/LX2 & Hungary & $\begin{array}{l}\text { Prunus } \\
\text { armeniaca }\end{array}$ & LT615187 & LT615187 & $\begin{array}{l}\text { A. Lantos } \\
\text { unpubl. }\end{array}$ \\
\hline $\begin{array}{l}\text { Monilinia } \\
\text { linhartiana }\end{array}$ & CBS 150.22 & Germany & $\begin{array}{l}\text { Mespilus } \\
\text { germanica }\end{array}$ & MH854729 & MH866235 & $\begin{array}{l}\text { Vu et al. } \\
2019\end{array}$ \\
\hline $\begin{array}{l}\text { Monilinia } \\
\text { megalospora }\end{array}$ & 619.2 & Norway & $\begin{array}{l}\text { Vaccinium } \\
\text { uliginosum }\end{array}$ & Z73788 & Z73753 & $\begin{array}{l}\text { Holst } \\
\text { Jensen et } \\
\text { al. 1997b }\end{array}$ \\
\hline $\begin{array}{l}\text { Monilinia } \\
\text { mumeicola }\end{array}$ & Hirodai \#3231 T? & Japan & Prunus mume & AB125620 & - & $\begin{array}{l}\text { Harada et } \\
\text { al. } 2004\end{array}$ \\
\hline $\begin{array}{l}\text { Monilinia } \\
\text { oxycocci }\end{array}$ & 1087.P & Norway & $\begin{array}{l}\text { Vaccinium cf. } \\
\text { oxycoccus }\end{array}$ & Z73789 & Z73754 & $\begin{array}{l}\text { Holst } \\
\text { Jensen et } \\
\text { al. 1997b }\end{array}$ \\
\hline Monilinia padi & $923 . \mathrm{K}$ & Norway & Prunus padus & Z73791 & Z73755 & $\begin{array}{l}\text { Holst } \\
\text { Jensen et } \\
\text { al. 1997b }\end{array}$ \\
\hline $\begin{array}{l}\text { Monilinia } \\
\text { polystroma }\end{array}$ & 2015/PS32 & Hungary & $\begin{array}{l}\text { Malus } \\
\text { domestica }\end{array}$ & LT615192 & LT615192 & $\begin{array}{l}\text { A. Lantos } \\
\text { unpubl. }\end{array}$ \\
\hline $\begin{array}{l}\text { Monilinia } \\
\text { seaverii }\end{array}$ & 1992.K & USA & Prunus serotina & Z73793 & Z73757 & $\begin{array}{l}\text { Holst } \\
\text { Jensen et } \\
\text { al. 1997b }\end{array}$ \\
\hline Monilinia urnula & 476.1 & Norway & $\begin{array}{l}\text { Vaccinium } \\
\text { vitis-idaea }\end{array}$ & Z73794 & Z73758 & $\begin{array}{l}\text { Holst } \\
\text { Jensen et } \\
\text { al. 1997b }\end{array}$ \\
\hline $\begin{array}{l}\text { Monilinia } \\
\text { vaccinii- } \\
\text { corymbosi }\end{array}$ & CBS 172.24 & N-America & $\begin{array}{l}\text { Vaccinium } \\
\text { corymbosum }\end{array}$ & МH854791 & МH854791 & $\begin{array}{l}\text { Vu et al. } \\
2019\end{array}$ \\
\hline $\begin{array}{l}\text { Mycopappus } \\
\text { alni }\end{array}$ & KUS-F27033 & Korea & Salix pierotii & KC753529 & KY696722 & $\begin{array}{l}\text { Park et al. } \\
2013\end{array}$ \\
\hline $\begin{array}{l}\text { Myriosclerotinia } \\
\text { scirpicola }\end{array}$ & 1435.P & Norway & $\begin{array}{l}\text { Scirpus } \\
\text { lacustris }\end{array}$ & Z81440 & Z81414 & $\begin{array}{l}\text { Holst } \\
\text { Jensen et } \\
\text { al. 1997b }\end{array}$ \\
\hline $\begin{array}{l}\text { Myriosclerotinia } \\
\text { sulcatula }\end{array}$ & CBS 303.31 & Denmark & Carex elata & MH855222 & МH866673 & $\begin{array}{l}\text { Vu et al. } \\
2019\end{array}$ \\
\hline Ovulinia azaleae & 1835.P & $?$ & Rhododendron & Z73797 & Z73760 & $\begin{array}{l}\text { Holst } \\
\text { Jensen et } \\
\text { al. 1997b }\end{array}$ \\
\hline Ovulinia azaleae & CBS 680.88 & Netherlands & Rhododendron & MH746075 & MH873840 & $\begin{array}{l}\text { Vu et al. } \\
2019\end{array}$ \\
\hline $\begin{array}{l}\text { Piceomphale } \\
\text { bulgarioides }\end{array}$ & $\begin{array}{l}\text { KL374, } \\
\text { TAAM:198322 }\end{array}$ & Estonia & Picea abies & LT158469 & KX090836 & $\begin{array}{l}\text { Pärtel et al. } \\
2016\end{array}$ \\
\hline $\begin{array}{l}\text { Pycnopeziza } \\
\text { sejournei }\end{array}$ & $\begin{array}{l}\text { KL267, J.H.P. } \\
11.054\end{array}$ & France & Hedera helix & LT158443 & KX090827 & $\begin{array}{l}\text { Pärtel et al. } \\
2016\end{array}$ \\
\hline $\begin{array}{l}\text { Pycnopeziza } \\
\text { sympodialis }\end{array}$ & $\begin{array}{l}\text { CBS } 332.39, \text { CUP } \\
25161\end{array}$ & USA & Alnus rugosa & MH856037 & МH867534 & $\begin{array}{l}\text { Vu et al. } \\
2019\end{array}$ \\
\hline $\begin{array}{l}\text { Rutstroemia } \\
\text { firma }\end{array}$ & $\begin{array}{l}\text { G.M. 2014-12- } \\
01.1\end{array}$ & Luxembourg & Quercus & KT876987 & KT876987 & $\begin{array}{l}\text { G. Marson } \\
\text { unpubl. }\end{array}$ \\
\hline $\begin{array}{l}\text { Rutstroemia } \\
\text { henningsiana }\end{array}$ & $608 . P$ & Norway & Carex rostrata & Z81442/KC533543 & Z81416 & $\begin{array}{l}\text { Holst } \\
\text { Jensen et } \\
\text { al. 1997b }\end{array}$ \\
\hline
\end{tabular}




\begin{tabular}{|c|c|c|c|c|c|c|}
\hline $\begin{array}{l}\text { Rutstroemia } \\
\text { luteovirescens }\end{array}$ & $\begin{array}{l}\text { KL217, } \\
\text { TU:104450 }\end{array}$ & Estonia & $\begin{array}{l}\text { Acer } \\
\text { platanoides }\end{array}$ & LT158431 & KX090814 & $\begin{array}{l}\text { Pärtel et al. } \\
2016\end{array}$ \\
\hline $\begin{array}{l}\text { Schroeteria } \\
\text { bornmuelleri } \\
\text { ana }\end{array}$ & H.U.V. 750 & Iran & $\begin{array}{l}\text { Veronica } \\
\text { rubrifolia }\end{array}$ & MW915653 & - & This study \\
\hline $\begin{array}{l}\text { Schroeteria } \\
\text { decaisneana } \\
\text { ana }\end{array}$ & $\begin{array}{l}\text { J.K. S1346, H.B. } \\
10206\end{array}$ & Germany & $\begin{array}{l}\text { Veronica } \\
\text { hederifolia } \\
\text { s.str. }\end{array}$ & MW915644 & MW915644 & This study \\
\hline $\begin{array}{l}\text { Schroeteria } \\
\text { decaisneana tel }\end{array}$ & A.U. 2273 & Germany & $\begin{array}{l}\text { Veronica } \\
\text { hederifolia agg. }\end{array}$ & MZ048345 & MZ048345 & This study \\
\hline $\begin{array}{l}\text { Schroeteria } \\
\text { decaisneana tel }\end{array}$ & WU 43982 & Germany & $\begin{array}{l}\text { Veronica } \\
\text { hederifolia agg. }\end{array}$ & MZ048346 & MZ048346 & This study \\
\hline $\begin{array}{l}\text { Schroeteria } \\
\text { delastrina ana }\end{array}$ & V.K. P1652-23 & Germany & $\begin{array}{l}\text { Veronica } \\
\text { arvensis }\end{array}$ & MW915652 & - & This study \\
\hline $\begin{array}{l}\text { Schroeteria } \\
\text { delastrina ana }\end{array}$ & V.K. P1652-27 & Germany & $\begin{array}{l}\text { Veronica } \\
\text { arvensis }\end{array}$ & MW915646 & MW915646 & This study \\
\hline $\begin{array}{l}\text { Schroeteria } \\
\text { delastrina ana }\end{array}$ & V.K. P1652-26 & Germany & $\begin{array}{l}\text { Veronica } \\
\text { arvensis }\end{array}$ & MW915645 & MW915645 & This study \\
\hline $\begin{array}{l}\text { Schroeteria } \\
\text { poeltii ana }\end{array}$ & J.K. S1304 & Greece & $\begin{array}{l}\text { Veronica } \\
\text { cymbalaria }\end{array}$ & MW915654 & - & This study \\
\hline $\begin{array}{l}\text { Schroeteria } \\
\text { poeltii ana }\end{array}$ & J.K. B2278 & Greece & $\begin{array}{l}\text { Veronica } \\
\text { cymbalaria }\end{array}$ & MW915647 & MW915647 & This study \\
\hline $\begin{array}{l}\text { Schroeteria } \\
\text { poeltii tel }\end{array}$ & C.V.L. 040117 & Spain & $\begin{array}{l}\text { Veronica } \\
\text { cymbalaria }\end{array}$ & MW915648 & MW915648 & This study \\
\hline $\begin{array}{l}\text { Sclerencoelia } \\
\text { fascicularis }\end{array}$ & $\begin{array}{l}\text { G.M. 2016-03- } \\
09.1\end{array}$ & Luxembourg & $\begin{array}{l}\text { Populus } \\
\text { tremula }\end{array}$ & MH194576 & MH194576 & $\begin{array}{l}\text { G. Marson } \\
\text { unpubl. }\end{array}$ \\
\hline $\begin{array}{l}\text { Sclerencoelia } \\
\text { fraxinicola }\end{array}$ & $\begin{array}{l}\text { H.B. } 9358, \\
\text { TAAM:198511 T }\end{array}$ & Germany & $\begin{array}{l}\text { Fraxinus } \\
\text { excelsior }\end{array}$ & KT876983 & KT876983 & $\begin{array}{l}\text { Pärtel et al. } \\
2016\end{array}$ \\
\hline $\begin{array}{l}\text { Scleromitrula } \\
\text { calthicola }\end{array}$ & 1368.1 & Norway & $\begin{array}{l}\text { Iris } \\
\text { pseudacorus }\end{array}$ & Z80887 & Z81422 & $\begin{array}{l}\text { Holst } \\
\text { Jensen et } \\
\text { al. 1997b }\end{array}$ \\
\hline $\begin{array}{l}\text { Scleromitrula } \\
\text { shiraiana }\end{array}$ & Hirayama062001 & $?$ & $?$ & AY789408 & AY789407 & $\begin{array}{l}\text { H.O. Baral } \\
\text { unpubl. }\end{array}$ \\
\hline $\begin{array}{l}\text { Scleromitrula } \\
\text { spiraeicola }\end{array}$ & 1336.1 & Norway & $\begin{array}{l}\text { Filipendula } \\
\text { ulmaria }\end{array}$ & Z81448 & Z81424 & $\begin{array}{l}\text { Holst } \\
\text { Jensen et } \\
\text { al. 1997b }\end{array}$ \\
\hline $\begin{array}{l}\text { Sclerotinia } \\
\text { 'binucleata'tel }\end{array}$ & $\begin{array}{l}\text { B.S.I. 10/7, WU } \\
43992\end{array}$ & Switzerland & $\begin{array}{l}\text { Ranunculus } \\
\text { ficaria }\end{array}$ & MZ048348 & MZ048348 & This study \\
\hline $\begin{array}{l}\text { Sclerotinia } \\
\text { bulborum }\end{array}$ & CBS 297.31 & USA & $?$ & MH855218 & MH866668 & $\begin{array}{l}\text { Vu et al. } \\
2019\end{array}$ \\
\hline $\begin{array}{l}\text { Ciboria } \\
\text { ploettneriana tel }\end{array}$ & WU 43984 & Germany & $\begin{array}{l}\text { Veronica } \\
\text { hederifolia agg. }\end{array}$ & MZ048354 & MZ048354 & This study \\
\hline $\begin{array}{l}\text { Sclerotinia } \\
\text { sclerotiorum }\end{array}$ & $\begin{array}{l}1980 \text { UF-70, } \\
\text { ATCC } 18683\end{array}$ & USA & bean pods & СР017820 & СР017820 & $\begin{array}{l}\text { Derbyshire } \\
\text { et al. } 2017\end{array}$ \\
\hline $\begin{array}{l}\text { Seaverinia } \\
\text { geranii }\end{array}$ & CBS 168.24 & USA & Geranium & MH854790 & MH866294 & $\begin{array}{l}\text { Vu et al. } \\
2019\end{array}$ \\
\hline $\begin{array}{l}\text { Septotinia } \\
\text { podophyllina }\end{array}$ & $\begin{array}{l}\text { CBS 318.37, CUP } \\
25277 \mathrm{~T}\end{array}$ & USA & $\begin{array}{l}\text { Podophyllum } \\
\text { peltatum }\end{array}$ & MH855916 & MH867422 & $\begin{array}{l}\text { Vu et al. } \\
2019\end{array}$ \\
\hline $\begin{array}{l}\text { Septotinia } \\
\text { populiperda }\end{array}$ & CBS 339.53 & Germany & Populus & MH857235 & MH101506 & $\begin{array}{l}\text { Vu et al. } \\
2019\end{array}$ \\
\hline $\begin{array}{l}\text { Stromatinia } \\
\text { cepivora }\end{array}$ & CBS 276.93 & Netherlands & Allium & MH862401 & MH874059 & $\begin{array}{l}\text { Vu et al. } \\
2019\end{array}$ \\
\hline Stromatinia & TNS:F-40103 & Japan & $\begin{array}{l}\text { Cryptomeria } \\
\text { Page 8/55 }\end{array}$ & AB926160 & AB926160 & T. Hosoya et \\
\hline
\end{tabular}




\begin{tabular}{|c|c|c|c|c|c|c|}
\hline \multicolumn{3}{|c|}{ cryptomeriae } & \multicolumn{3}{|l|}{ japonica } & \multirow{2}{*}{$\begin{array}{l}\text { al. unpubl. } \\
\text { Vu et al. } \\
2019\end{array}$} \\
\hline $\begin{array}{l}\text { Stromatinia } \\
\text { gladioli }\end{array}$ & CBS 265.28 T & $\mathrm{N}$-America & Gladiolus & MH855008 & MH866477 & \\
\hline $\begin{array}{l}\text { Stromatinia } \\
\text { narcissi }\end{array}$ & CBS 339.33 & Netherlands & Narcissus & MH855451 & MH866916 & $\begin{array}{l}\text { Vu et al. } \\
2019\end{array}$ \\
\hline $\begin{array}{l}\text { Stromatinia } \\
\text { pyrolae }\end{array}$ & 1471.S & Norway & Pyrola minor & Z73798 & Z73761 & $\begin{array}{l}\text { Holst } \\
\text { Jensen et } \\
\text { al. 1997b }\end{array}$ \\
\hline $\begin{array}{l}\text { Stromatinia } \\
\text { rapulum }\end{array}$ & 1243.1 & Norway & $\begin{array}{l}\text { Polygonatum } \\
\text { multiflorum }\end{array}$ & Z73801 & Z73763 & $\begin{array}{l}\text { Holst } \\
\text { Jensen et } \\
\text { al. 1997b }\end{array}$ \\
\hline $\begin{array}{l}\text { Stromatinia } \\
\text { rapulum tel }\end{array}$ & A.U. Dum03 & Germany & $\begin{array}{l}\text { Polygonatum } \\
\text { odoratum }\end{array}$ & MZ048352 & MZ048352 & This study \\
\hline $\begin{array}{l}\text { Valdensia } \\
\text { heterodoxa }\end{array}$ & 485.2 & Norway & $\begin{array}{l}\text { Vaccinium } \\
\text { myrtillus }\end{array}$ & Z81447 & Z81423 & $\begin{array}{l}\text { Holst } \\
\text { Jensen et } \\
\text { al. 1997b }\end{array}$ \\
\hline
\end{tabular}

\section{Results}

\section{Molecular results}

The obtained sequences of the three Schroeteria decaisneana samples fully concur in the ITS region between the two apothecial isolates (teleomorph) and the sorus isolate (anamorph), except for $1 \mathrm{nt}$ in the ITS1 in one of the apothecial isolates (Tab. 2). Also in the LSU D1D2 no difference was observed between the two apothecial isolates and the sorus isolate (Tab. 2). The two S. poeltii sequences likewise fully concur in the ITS and LSU D1-D2 region between apothecial and sorus isolate, except for $1 \mathrm{nt}$ in the LSU. Considering the interspecific distances among the Schroeteria species and the identity of the host species, our result proves that teleomorph and anamorph belong together.

The interspecific distances in the ITS (457-462 nt in core clade of Schroeteria) and LSU D1-D2 (598 nt) range at 5-6.3\% / 2.5-2.7\% within the core clade, but at 14\% / 8.5-9.6\% between core clade and Schroeteria poeltii, 16.7-18\% / 8.9-9.7\% between core clade and Ciboria ploettneriana, and 9.2\% / 3.7-3.9\% between Schroeteria poeltii and Ciboria ploettneriana, respectively. The S1506 intron is absent in all sequences in which the 3'-end region of SSU was included (the region is missing in Schroeteria bornmuelleri).

Table 2. Inter- and intraspecific distance matrix of the ITS1-5.8S-ITS2 region (before slash) and LDU D1-D2 domain (after slash) for Schroeteria spp. in comparison with Ciboria ploettneriana (p-distances, transitions + tansversions, pairwise deletion).

\begin{tabular}{|llllll|}
\hline & S. decaisneana & S. delastrina & S. bornmuelleri & S. poeltii & Cib. ploettneriana \\
\hline S. decaisneana & $0-0.2 / 0 \%$ & & & & \\
\hline S. delastrina & $5-5.3 / 2.5-2.7 \%$ & $0-0.4 / 0.2 \%$ & & & \\
\hline S. bornmuelleri & $6-6.3 /-\%$ & $5.2 /-\%$ & $-/-$ & & \\
\hline S. poeltii & $14-14.3 / 9.4-9.6 \%$ & $14.2-14.7 / 8.5-8.9 \%$ & $13.8 /-\%$ & $0 / 0.2 \%$ & \\
\hline Cib. ploettneriana & $17.2-18 / 9.7 \%$ & $17.2-17.6 / 8.9-9 \%$ & $16.7 /-\%$ & $9.2 / 3.7-3.9 \%$ & $-/-$ \\
\hline
\end{tabular}

A strongly supported Schroeteria core clade is formed in our combined maximum likelihood analysis of ITS+LSU (PI. 1), but also in separate analyses of ITS and LSU (S1, S2). The clade comprised S. decaisneana, S. delastrina, and S. bornmuelleri, and nested in our combined analysis in an unsupported clade with various Monilinia spp. of section Disjunctoriae growing on fruits of Ericaceae and Rosaceae (PI. 1). When separately analysing the ITS region (S1), this clade was strongly supported but included also Ciborinia foliicola, $C$. whetzelii, and Ciboria betulae, whereas when separately analysing LSU (S2) the Schroeteria core clade clustered with medium support with Ciboria shiraiana (on Morus), which in the other two analyses formed a supported clade with C. carunculoides (also on Morus) outside Sclerotiniaceae and Rutstroemiaceae.

The Schroeteria core clade clustered particularly with two Ericaceae inhabiting species: it formed a medium (PI. 1, S1) or strongly (S3) supported sister clade of $M$. jezoensis, though with a rather long branch, and together with this species a less supported sister clade of $M$. 
azaleae (PI. 1, S1). Both species grow on Rhododendron and are members of the Monilinia alpina group of section Disjunctoriae, to which also M. cassiopes belongs (Batra 1991: 102), but apparently also Stromatinia pyrolae.

In contrast to the phylogenetic affiliation of the Schroeteria core clade with Monilinia section Disjunctoriae, Schroeteria poeltii clustered distant from Schroeteria s.str. It formed an unsupported (PI. 1) or strongly supported (S3) distant sister clade to the supported clade of Sclerotinia bulborum and S. 'binucleata' (an undescribed species of Sclerotinia s.l. parasitizing on Ranunculus ficaria and Corydalis cava). Ciboria ploettneriana clustered with comparatively short branches with these and other typical members of Sclerotinia, Stromatinia, and Grovesinia in an unsupported clade (PI. 1, S1).

\section{Morphological results}

In the following, Ciboria ploettneriana, Schroeteria decaisneana, and S. poeltii are described in detail from their teleomorph, the latter two also from their anamorph.

\section{Key to species of Sclerotiniaceae with known teleomorph growing on Veronica seeds}

1. Ascospores mainly * $12.5-16.5 \times 6-7.5 \mu \mathrm{m}$, with several LBs $0.5-0.8 \mu \mathrm{m}$ diam. grouped near each end, (2-)4-nucleate; living paraphyses containing \pm refractive vacuolar bodies (VBs) in terminal cell; on blackened seeds of Veronica hederifolia agg., climate temperate humid Ciboria ploettneriana

2. Ascospores mainly *10-13 × 5.5-6.5 $\mu \mathrm{m}$, with 1(-2) LBs 1.4-2.7 $\mu \mathrm{m}$ diam. near each end, uninucleate; living paraphyses without refractive vacuoles in terminal cell .2

2. Apothecial stipes 3-13 mm long; ascospores ellipsoid to fusoid, LBs subpolar, 1.4-2.7 $\mu \mathrm{m}$ diam.; on light to bright (grey-)brown seeds of Veronica hederifolia agg., climate temperate humid Schroeteria decaisneana

3. Apothecial stipes 5-25 mm long; ascospores ellipsoid, LBs more polar, 1.5-1.8 $\mu \mathrm{m}$ diam.; on blackened seeds of Veronica cymbalaria, climate mediterranean semihumid Schroeteria poeltii

Table 3. Comparison of teleomorph characteristics of Schroeteria decaisneana, S. poeltii, and Ciboria ploettneriana. \# = data evaluated from Nagler et al. (1989). 


\begin{tabular}{|c|c|c|c|}
\hline & Schroeteria decaisneana & Schroeteria poeltii & Ciboria ploettneriana \\
\hline $\begin{array}{l}\text { Ascospores size } \\
{[\mu \mathrm{m}]}\end{array}$ & $\begin{array}{l}*(9.5-) 11-13(-14.5) \times(5-) 5.5- \\
6.5(-6.7)\end{array}$ & $\begin{array}{l}*(9.5-) 10-11(-11.3) \times \\
(5.3-) 5.5-6(-6.3)\end{array}$ & $\begin{array}{l}*(10.5-) 12.5-16.5(-19) \times(5.5-) 6- \\
7.5(-9)\end{array}$ \\
\hline - shape & ellipsoid to fusoid or slightly ovoid & ellipsoid to slightly ovoid & ellipsoid- to ovoid-fusoid \\
\hline - LBs (living state!) & $\begin{array}{l}1(-2) \text { LBs of } 1.4-2.7 \mu \mathrm{m} \text { diam. } \\
\text { and some small ones near each } \\
\text { end }\end{array}$ & $\begin{array}{l}\text { 1(-2) LBs of }(1-) 1.5-1.8 \mu \mathrm{m} \\
\text { diam. } \\
\text { and some small ones at each } \\
\text { end }\end{array}$ & $\begin{array}{l}1(-2) \text { LBs of } 0.5-0.8(-1) \mu \mathrm{m} \text { diam. } \\
\text { and some small ones near each end }\end{array}$ \\
\hline $\begin{array}{l}\text { - nuclei in } \\
\text { ascospores }\end{array}$ & 1 nucleus, $2.8-3 \mu \mathrm{m}$ diam. & 1 nucleus, $3-3.2 \mu \mathrm{m}$ diam. & (2-)4-nuclei, 2.2-2.9 $\mu \mathrm{m}$ diam. \\
\hline Phialides $[\mu \mathrm{m}]$ & $+2.5-5 \times 1.5-3$ & $8-20 \times 3.5-5.8^{\#}$ & $* 6-10 \times 2.6-3.5(-4)$ \\
\hline $\begin{array}{l}\text { - phialoconidia } \\
{[\mu \mathrm{m}]}\end{array}$ & $\star 2.8-3.6 \times 2.6-3.4$ & $\begin{array}{l}(2.7-) 3-3.6(-4) \times(2.7-) 2.9- \\
3.5(-3.8)^{\#}\end{array}$ & $* 2.5-3.2 \times 2.5-3$ \\
\hline Asci $[\mu \mathrm{m}]$ & $\begin{array}{l}*(145-) 157-185(-192) \times 11- \\
12.3(-13)\end{array}$ & *145-160 × 9.5-10.5(-10.8) & *180-210 × (10-)11-12(-13) \\
\hline $\begin{array}{l}\text { Paraphysis } \\
\text { terminal cells }\end{array}$ & with non-refractive vacuoles & with non-refractive vacuoles & $\begin{array}{l}\text { with slightly to strongly refractive } \\
\text { VBs }\end{array}$ \\
\hline Ectal excipulum & $\begin{array}{l}\text { vertically or often horizontally } \\
\text { oriented } \\
\text { textura globulosa(-prismatica) }\end{array}$ & $\begin{array}{l}\text { vertically oriented } \\
\text { textura globulosa(-prismatica) }\end{array}$ & $\begin{array}{l}\text { vertically oriented } \\
\text { textura globulosa-prismatica }\end{array}$ \\
\hline $\begin{array}{l}\text { - lower flank cells } \\
{[\mu \mathrm{m}]}\end{array}$ & $\begin{array}{l}*(16-) 20-45(-70) \times(12-) 15- \\
28(-35)\end{array}$ & $\star 20-50 \times 15-30$ & $\star 20-40(-58) \times 15-25(-30)$ \\
\hline $\begin{array}{l}\text { - marginal cells } \\
{[\mu \mathrm{m}]}\end{array}$ & $\star 38-70 \times 6-10$ & $\star 25-35 \times 13-15$ & $\star 8-15(-25) \times 5-11.5$ \\
\hline - cells in stipe $[\mu \mathrm{m}]$ & $\begin{array}{l}\star 28-46 \times 3-4 \\
\text { textura porrecta }\end{array}$ & $\begin{array}{l}\text { †25-40 × 6-9.5 } \\
\text { textura prismatica-porrecta }\end{array}$ & $\begin{array}{l}\star 20-45 \times 7-17 \\
\text { textura prismatica }\end{array}$ \\
\hline $\begin{array}{l}\text { Apoth. disc diam. } \\
\text { [mm] }\end{array}$ & $1.5-3.5$ & $(1-) 1.3-2.5(-3)$ & $(1.2-) 2-4$ \\
\hline - stipe colour & $\begin{array}{l}\text { medium grey-brown, near base } \\
\text { blackish-brown }\end{array}$ & $\begin{array}{l}\text { ochraceous, near base blackish- } \\
\text { brown }\end{array}$ & $\begin{array}{l}\text { whitish to creamish, sometimes } \\
\text { brownish below }\end{array}$ \\
\hline - stipe size [mm] & $\begin{array}{l}(3-) 5-10(-13) \times(0.2-) 0.4-0.6(- \\
0.8)\end{array}$ & $5-18 \times 0.2-0.55$ & $2-7 \times(0.35-) 0.5-0.8(-1)$ \\
\hline $\begin{array}{l}\text { Seed size } \\
\text { (infected) [mm] }\end{array}$ & $2-2.5$ & $(0.9-) 1.7-2.8$ & $2-3.2$ \\
\hline - surface & light to bright (grey-)brown & bright grey-brown to blackish & blackish-brown to black \\
\hline $\begin{array}{l}\text { Phenology } \\
\text { (apothecia) }\end{array}$ & $\mathrm{XI}-\mathrm{V}$ & 1 & IV-V \\
\hline Host & Veronica hederifolia agg. & Veronica cymbalaria & Veronica hederifolia agg. \\
\hline climate & temperate humid & $\begin{array}{l}\text { meso-/supramediterranean } \\
\text { semihumid }\end{array}$ & temperate humid \\
\hline
\end{tabular}

Ciboria ploettneriana (Kirschst. in Rehm) N.F. Buchw., K. Vet. Landbohøjsk., Aarsskr. 32: 165 (1949) - Pls 2-6

ESclerotinia ploettneriana Kirschst., in Rehm, Ascom. exsicc.: no. 1603 (1905), nom. inval., Art. 38.1(a) ICN

$\equiv$ Sclerotinia ploettneriana Kirschst., in Rehm, Annls mycol. 3(5): 411 (1905), nom. inval., Art. 38.1(a) ICN

三Sclerotinia ploettneriana Kirschst., Verh. Bot. Ver. Prov. Brandenburg 48: 43 (1906) 
Etymology: named after the collector, the German Traugott Plöttner (1853-1923), who frequently accompanied W. Kirschstein (18631946) on his excursions (Kummer 2010).

Lectotype (designated here, MBT 10000619): Germany, Brandenburg, Groß Behnitz, Hasellake, on black stromatized seeds of Veronica hederifolia agg., 27.IV.1905, W. Kirschstein (B 70 0100006).

DESCRIPTION. Teleomorph: Apothecia fresh (1.2-)2-4 mm diam., non-gelatinous, disc light to bright ochraceous-brown, slightly concave, finally flat, darker brown with age, margin thin, not protruding, smooth to very finely whitish denticulate, exterior pale to light ochraceous, smooth to slightly hairy, receptacle at base $0.7 \mathrm{~mm}$ thick, at margin $0.35 \mathrm{~mm}$; stipe $2-7 \times(0.35-) 0.5-0.8(-1) \mathrm{mm}$, whitish to pale cream, at base often darker brown, usually somewhat hairy and with adhering particles, emerging singly (rarely also in pairs) from concave or convex side of the seed. Asci ${ }^{*} 180-210\{2\} \times(10-) 11-12(-13) \mu \mathrm{m}\{3\},+150-173 \times 8-10(-11) \mu \mathrm{m}\{1\}$, protruding *5-30 $\mu \mathrm{m}$ beyond paraphyses or $(\dagger) \pm$ equalling the paraphyses, with 8 equal-sized spores (in overmature apothecia also unequal-sized), pars sporifera *61-73 um long, spores obliquely (sub)biseriate, $+65-83 \mu \mathrm{m}$, spores subbiseriate to uniseriate; apex ( $\dagger$ ) hemispherical to moderately truncate, apical thickening immature or mature $+2-3.8 \mu \mathrm{m}$ thick, apical ring blue in IKI \{4\}, euamyloid (BB), of Sclerotinia-type, lower ring strongly blue, upper parts less so; base with short and thick stalk, arising from croziers $\{3\}$. Ascospores *(10.5-)12.5-16.5(-19) $\times$ $(5.5-) 6-7.5(-9) \mu \mathrm{m}\{4\},+(11-) 12-15(-16) \times(4.5-) 4.8-6 \mu \mathrm{m}\{5\}$, ellipsoid-fusoid to ellipsoid-fusiform (homopolar) or often distinctly ovoid-fusoid (heteropolar), ends obtuse to subacute, \pm equilateral; containing a few minute LBs near each end, $(0.2-) 0.5-0.8(-1)((-2))$ $\mu \mathrm{m}$ diam. $\{4\}, \mathrm{OCI} 0.5-1(-2)$, with $((1-))(2-) 4$ nuclei in centre $\{4\}$, without distinct glycogen; surrounded by a very delicate sheath that slips off the spore after ejection, spore wall surface CRB-; overmature spores 0-1(-2)-septate (septum median or sometimes eccentrical when 1-septate), ${ }^{*} 17-19 \times 7.5-9 \mu \mathrm{m}$, without LBs; forming germ tubes and/or phialides. Paraphyses apically uninflated to slightly clavate or lageniform, terminal cell *(20-)42-100(-133) $\times(3-) 4-5(-5.7) \mu \mathrm{m}\{3\},+2.5-4 \mu \mathrm{m}$ wide $\{1\}$, lower cells *17-39 $\times 2.2-3.5 \mu \mathrm{m}$ $\{2\}$; branched in lower and middle part; terminal cell containing hyaline, slightly to strongly refractive vacuolar bodies (VBs) in (11-)15$50(-70) \mu \mathrm{m}$ long upper part $\{3\}$, VBs staining turquoise in $\mathrm{CRB}$, in $\mathrm{H}_{2} \mathrm{O}$ turning light purplish-pink with age (vital state) \{2\}, without SCBs; when senescent ensheathed by an ochre-brass-brown exudate along entire length. Subhymenium light ochre, $30 \mu \mathrm{m}$ thick, of dense textura intricata. Medullary excipulum subhyaline, non-gelatinized, at base of receptacle 200-400 $\mu \mathrm{m}$ thick, near margin $100 \mu \mathrm{m}$, upper part of \pm loose t. intricata, individual cells *40-110 *6-16 $\mu \mathrm{m}$, smooth, without exudate; lower part of dense, horizontal t. porrecta, 150 $\mu \mathrm{m}$ thick at base of receptacle, sharply delimited from ectal excipulum, in stipe of t. porrecta. Ectal excipulum \pm hyaline, $50-150 \mu \mathrm{m}$ thick at lower flanks, of thin-walled (wall +0.2-0.4 $\mu \mathrm{m}$ thick), \pm vertically oriented t. globulosa-prismatica, cells *20-40 $(-58) \times 15-25(-30) \mu \mathrm{m}$ $\{2\}$, cortex of smaller globose cells which sometimes form clavate to stalked hair-like protuberances of *10-21 $\times 8-10(-11) \mu \mathrm{m}$; at mid flanks 30-40 $\mu \mathrm{m}$ thick, at margin $20 \mu \mathrm{m}$ thick, with ochre-brown exudate, marginal cells *8-15(-25) $\times 5-11.5 \mu \mathrm{m}\{2\}$, ellipsoid to clavate or stalked; exterior without hyphal layer, at lower flanks with hair-like, globose to clavate or stalked cells of *10-21 $\times 8-10(-11) \mu \mathrm{m}$, often containing VBs; in stipe of large-celled, subhyaline t. prismatica (cells $* 20-45 \times 7-17 \mu \mathrm{m}$ ), covered by a thin layer of hyphoid, $* 3-7 \mu \mathrm{m}$ wide elements, with scattered, indistinctly protruding, irregularly clavate to stalked, thin-walled, hair-like cells of *13-28 $\times 6-8 \mu \mathrm{m}$ that contain VBs, at very base of stipe of dark red-brown t. angularis. Rhomboid crystals abundantly present in medullary excipulum $\{5\}$, diagonal diameter 8-22(-32) $\mu \mathrm{m}$, small scattered crystals occurring on ectal excipulum and hymenium, crystals present also in medullary excipulum of basal part of stipe and a few in mycelial tissue within seed, sometimes forming druses 10-20 $\mu \mathrm{m}$ diam.

Amyloidity of tissue: subhymenium $\{2\}$ and outer medullary excipulum $\{2\}$ pale to distinctly bluish in IKI (sometimes only visible after squashing). - Anamorph: Cultural characteristics: In pure culture on MEA the ascospores tardily germinated but did not form a mycelium. Smut-like synanamorph unknown. Microconidial synanamorph formed on ascospores germinating in senescent apothecia, producing phialides of *6-10 $\times 2.6-3.5(-4) \mu \mathrm{m}$ that emerge terminally or laterally, either directly or on short to long germ tubes; phialoconidia globose to subglobose, $* 2.5-3.2 \times 2.5-3 \mu \mathrm{m}\{3\}$, smooth, with a single eccentrical LB 1.2-2 $\mu \mathrm{m}$ diam.

Habitat: on fallen, heavily stromatized, previous year's seeds of Veronica hederifolia agg. $\{20 / 9\}$, seeds $2-3.2 \mathrm{~mm}$ diam., hard, surface \pm rugose, entirely blackish-brown to black due to abundant, dark brown intracellular hyphae in epidermial layer and more sparse in outer parenchym cells. Desiccation tolerance: not tested for apothecia (probably intolerant), but surviving min. 9 months within the dry stromatized seeds. Phenology: IV-V. Altitude: 30-195 m. Geology: on basophilic to calcareous or more acidic soil: Muschelkalk (partly covered by loess), pleist- \& holocene marl, sand \& gravel, and fluviatile sediments.

\begin{tabular}{|rlllllll|}
\hline \multicolumn{7}{|c|}{ Phenology of Ciboria ploettneriana } \\
& Feb-2 & Mar-1 & Mar-2 & Apr-1 & Apr-2 & May-1 & May-2 \\
\hline teleomorph & - & - & - & 9 & 9 & 2 & - \\
\hline
\end{tabular}


Specimens included (all on fallen seeds of Veronica hederifolia agg.).

Teleomorph: Germany: Mecklenburg-Vorpommern, 3.7 km S of Wismar, 1.2 km NE of Metelsdorf, slope at road, MTB 2134/232, 30 m, 14.IV.2019, T. Richter, vid. M. Reul (T.R., M.R. 6806). - Berlin, 8.5 km SE of Berlin, Treptow, Baumschulenweg, Späth-Arboretum, 37 m, MTB 3546/24, 30.IV.1992, D. Benkert, vid. V. Kummer (B 70 0009941, d.v.). - Brandenburg, 22.5 km NE of Brandenburg, SW of Groß Behnitz, Hasellake, 35 m, MTB 3442/123, 14.IV.1905, W. Kirschstein, vid. V. Kummer (B 70 0100005). - ibid., 27.IV.1905, W. Kirschstein, vid. V. Kummer (B 70 0100006, lectotype). - $1.7 \mathrm{~km} \mathrm{SW}$ of Teupitz, $1.5 \mathrm{~km}$ SE of Egsdorf, between Mittel-Mühle and Tornower See, 45 m, MTB 3847/43, 27.IV.1972, D. Benkert, vid. V. Kummer (B 70 0009940, d.v.). - Sachsen-Anhalt, 2.2 km SE of Merseburg, WSW of Trebnitz, Werder canal, MTB 4638/31, 88 m, 20.VI.2003, G. Hensel (blackened seeds without apothecia, deposited at the same day in a box in the garden of M. Huth); 3.IV.2004, M. Huth (apothecia developed in box, M.H.). - ibid., 30.IV.2019, G. Hensel (blackened seeds without apothecia, H.B. 10210). - 4.3 km NE of Freyburg, W of Zeuchfeld, above vineyard, MTB 4736/42, 195 m, 13.IV.2009, P. \& S. Rönsch (P.R., H.B. 9037). - ibid., 15. \& 23.IV.2010, U. Richter. - 1.7 km ENE of Freyburg, NW-corner of Alte Göhle, Bauernholz, 185 m, MTB 4736/4, 2.V.2003, M., W. \& E. Huth (W.H.). - ibid., 20.VI.2003, M. Huth \& P. Rönsch (blackened seeds without apothecia, deposited at the same day in a box in the garden of M. Huth); 15. \& 18.IV.2004, M. Huth \& P. Rönsch (apothecia developed in box, M.H. \& P.R.). - ibid., 15.IV.2007, P. \& S. Rönsch (P.R., sin. doc.). - ibid., 22.IV.2010, U. Richter et al. (WU 43984, sq.: ITS/LSU MZ048354). - ibid., 23.IV.2010 U. Richter (H.B. $9271 \varnothing)$. -5.5 km WSW of Freyburg, S of Hirschroda, Hirschrodaer Graben, 185 m, MTB 4836/1, 12.IV.2004, P. Rönsch, S. Thieme, M. Huth (P.R.). - 4.3 km NW of Naumburg, 1 km WNW of Roßbach, Scherbitzberg-Schlucht, MTB 4836/2, 195 m, 8.IV.2009, W. Huth (ø). - ibid., 2.V.2019, W. Huth (W.H.).

Taxonomic remarks: Ciboria ploettneriana resembles Schroeteria decaisneana in most of its morphological traits, including various microscopic details, such as size of asci and paraphyses, size and shape of medullary and ectal excipular cells, IKI-reaction of ascus apex and medullary excipulum, and presence of crystals. The species deviates macroscopically in light-coloured, often whitish, somewhat shorter apothecial stipes with a lighter colour at the base, and seeds with a more blackish surface, causing a strong optical contrast between stipe and seed, in contrast to grey-brown seeds in S. decaisneana. Microscopically, Ciboria ploettneriana deviates from Schroeteria decaisneana in distinctly larger, slightly more heteropolar ascospores with often pointed, subacute ends. Under vital study, Ciboria ploettneriana differs in ascospores with a distinctly lower lipid content composed of much smaller LBs and (2-)4 nuclei instead of only one, and in \pm strongly refractive vacuoles (VBs) in the terminal cells of paraphyses (Tab. 3). Less evident or possibly variable features of $C$. ploettneriana are slightly longer asci, slightly smaller conidia formed on longer phialides, and an ectal excipulum of vertically oriented cells in the receptacle (in $S$. decaisneana often horizontal) and wider cells in the stipe (textura prismatica vs. t. porrecta), also with much shorter cells at the margin (Tab. 3).

Variation: Ascus and spore size was rather consistent among the specimens studied. Also the size of LBs never exceeded $1 \mu \mathrm{m}$ diam., with rare exceptions of single spores. The number of nuclei in the spores varied between two and four within all four samples in which living spores have been studied in detail (H.B. 9037 \& 9271, M.R. 6806, 2.V.2019), but the tetranucleate spores were often distinctly more numerous than the binucleate spores when regarding only mature, freshly ejected spores.

Cultural studies: Microconidia were abundantly produced from the ascospores in senescent apothecia after incubation in a moist chamber. When shot on agar medium (MEA), the ascospores did not produce a mycelium even after several weeks of incubation at room temperature.

In two of the here studied samples, apothecia were obtained after incubation of blackened seeds placed in June directly. In this the apothecia developed during April of the following year.

Nomenclature and misidentifications: Hein \& Gerhardt (1981) listed four voucher specimens as syntypes of Sclerotinia ploettneriana in B (Botanisches Museum Berlin-Dahlem): one from Rathenow (29.X.1899), two from Groß Behnitz (14. \& 27.IV.1905), and one containing a mixture taken from both sites (29.X.1899 and 'April 1905'). Kirschstein's protologue mentions both sites with the dates 29.X.1899 and IV.1905 (without specifying the exact date in April). Under the latter date Kirschstein distributed the fungus as an exsiccata in Rehm: Ascom. exsicc. no. 1603. In the present study all four specimens, which now bear the herbarium numbers B $700100003-0100006$, were examined by one of us (V. Kummer).

The first report of Sclerotinia ploettneriana in Rehm (1905 no. 1603, in sched.) and also the publication of this exsiccata in Annales Mycologici (Rehm 1905) is invalid, because only the collection data was provided but no description. Valid publication with description was done in Kirschstein (1906). The unillustrated protologue reports apothecia 2-3 mm diam., stipes 1-10 × $0.5 \mathrm{~mm}$, emerging singly or 
up to four from one seed, asci 160-180 × 10-12 $\mu \mathrm{m}$, and oval spores of 15-18 × 6-7 $\mu$ m with 1-2 small oil drops. Kirschstein emphasized the black stromatization of the seeds in contrast to the whitish uninfected seeds.

The Rathenow specimen (B 70 0100003) contains principally about ten light brown seeds of Veronica hederifolia agg. from which apothecia with ellipsoid spores of $+9-11 \times 5-6 \mu \mathrm{m}$ emerge (PI. 13). The light seed colour and the small spores indicate that this collection represents Schroeteria decaisneana, although the spores often contained more than one comparatively small oil drop in each half. A single seed without adhering apothecium appears to belong to Ciboria ploettneriana because of its black-brown colour. The date of this collection (end of October) coincides with the phenology of the $S$. decaisneana teleomorph which comprises autumn, winter, and spring, according to our study.

The two samples from Groß Behnitz (B 70 0100005-6, one shown on PI. 6: 1) each contain numerous bright to dark black-brown seeds of Veronica hederifolia agg., and apothecia which much better fit the protologue of Sclerotinia ploettneriana regarding spore shape (ellipsoid to fusoid, rarely clavate) and spore size (B 70 0100005: †11-16 × 5-6 $\mu \mathrm{m}$, B 70 0100006: †12-15 × 4.5-6 $4 \mathrm{~m}$, examined in water). Because of the small spore size in the Rathenow collection we conclude that the protologue derives from the large-spored species alone and not from a mixture with Schroeteria decaisneana. Therefore, we here designate one of the two specimens from Groß Behnitz, B 70 0100006, as lectotype of Sclerotinia ploettneriana.

The examined duplicate of Rehm's exsiccata (B 70 0100004) provided a surprize: it does not contain any seeds of Veronica, but half a dozen of sclerotia with apothecia of an undetermined Sclerotiniaceae, also a few seeds of a ? Stellaria. The original label indicates that this exsiccata was composed of a mixture of two collections: the vast majority of the material was from Groß Behnitz (IV.1905), whereas a sparse minority came from Rathenow (29.X.1899). Other duplicates of this exsiccata might therefore actually contain seeds of Veronica with apothecia of Ciboria ploettneriana.

Ecology: Ciboria ploettneriana was recorded near Freyburg at three sites, in a thermophilous deciduous forest with UImus minor bordered by Prunus spinosa (Zeuchfeld, PI. 12), in a thermophilous Querco-Carpinetum (Alte Göhle), and in a more shady Aceri-Fraxinetum (Hirschrodaer Graben). The site near Merseburg was a ?Pruno-Fraxinetum river bank forest with Prunus padus (Elster-Luppe-Aue), that near Naumburg a nitrophilous Quercus-Fraxinus forest edge (Alliarion, PI. 5), and that near Wismar a narrow forest strip of Acer, Aesculus and Tilia between road and farmland. Monilinia johnsonii on Crataegus fruits occured together with Ciboria ploettneriana at the site near Naumburg.Besides the collections from Mecklenburg-Vorpommern, Brandenburg (including Berlin), and Sachsen-Anhalt as listed under Specimens included, no further unequivocal records of Ciboria ploettneriana came to our notice.

Schroeteria decaisneana (Boud.) De Toni, in Saccardo, Syll. fung. 7(2): 501 (1888) - Pls 7-14

三 Thecaphora decaisneana Boud., Bull. Soc. mycol. Fr. 2: 167 (1886)

$\equiv$ Geminella decaisneana (Boud.) Boud., Bull. Soc. mycol. Fr. 3(2): 150, pl. 15 fig. 2 (1887)

三Schizonella decaisneana (Boud.) Thirum. \& M.D. Whitehead, Am. J. Bot. 55: 186 (1968)

= Schroeteria parvispora (Bref.) Ferd. \& Winge, Dansk bot. Ark. 2(1): 4 (1914)

三 Geminella parvispora Bref., Unters. Gesamtgeb. Mykol. 15: 75 (1912)

Etymology: named after the French botanist Joseph Decaisne (1807-1882), who made the first record.

Type: collected in 1868 by J. Decaisne in the surroundings of Versailles, and later during several years in spring and summer by E. Boudier near Montmorency (Paris), always on "Veronica hederacea" (= V. hederifolia agg.). No lectotype appears to have been designated, and no material was ordered in this study.

DESCRIPTION. Teleomorph: Apothecia fresh 1.5-3.5 mm diam., non-gelatinous, disc light ochraceous-brown, slightly concave, finally flat to medium convex, darker brown with age, margin thin, not protruding, \pm smooth, sometimes deeper red-brown, exterior pale ochraceous, finely rough, receptacle at base $0.5-0.75 \mathrm{~mm}$ thick, at margin 0.25-0.35 mm; stipe (3-)5-10(-13) × (0.2-)0.4-0.6(-0.8) mm, concolorous with receptacle or darker red-brown, especially in lower part, black-brown at base, here or also upwards with \pm appressed hairs; one or sometimes $2-3(-4)$ stipes emerging from concave or convex side of the seed. Asci *(145-)157-185(-192) × 11-12.3(-13) $\mu \mathrm{m}\{2\},+118-147 \times(7.5-) 8.5-10(-11.7) \mu \mathrm{m}\{2\}$, protruding *25-35 $\mu \mathrm{m}$ beyond paraphyses or $+10 \mu \mathrm{m}$ shorter up to $10 \mu \mathrm{m}$ longer than paraphyses, containing 8 equal-sized spores, pars sporifera *(48-)52-65 $\mu \mathrm{m}$ long, spores obliquely (sub)biseriate, †48-72 $\mu \mathrm{m}$, spores uniseriate; apex $(\dagger)$ hemispherical to subtruncate or obtuse, apical thickening $+1.7-2.8 \mu \mathrm{m}$ thick when \pm mature, apical ring medium to

Page 14/55 
strongly blue in IKI $\{5\}$, euamyloid (BB), sometimes slightly hemiamyloid (rB, very dirty reddish-grey at high concentration), of Sclerotiniatype, all parts equally reactive or sometimes upper ring paler, upper and lower ring deep blue when KOH-pretreated; base with (very) short and thick stalk arising from croziers $\{3\}$. Ascospores *(9.5-)11-13(-14.5) × (5-)5.5-6.5(-6.7) $\mu \mathrm{m}\{5\},+(8.5-) 9-11(-12.8) \times 4.7-6.2(-$ 6.5) $\mu \mathrm{m}\{5\}$, ellipsoid to fusoid (homopolar) or slightly ovoid (heteropolar), ends rounded to obtuse, rarely subacute, \pm equilateral; containing two medium-sized LBs (1.4-)1.8-2.4(-2.7) $\mu \mathrm{m}$ diam. \{4\}, each surrounded by a few small LBs, OCI (2-)3, sometimes with two small glycogen regions staining dextrinoid (red-brown in IKI), with 1 nucleus of $2.8-3 \mu \mathrm{m}$ diam. in centre $\{1\}$; surrounded by a very delicate sheath that slips off the spore after ejection, spore wall surface CRB-; overmature 0-1-septate (septum median, rarely strongly eccentrical), *10.5-12.5 × 5-6 $\mu \mathrm{m}$, without or with only small LBs; forming germ tubes and/or phialides. Paraphyses apically uninflated to slightly clavate $\{4\}$, in some apothecia frequently \pm strongly clavate to capitate or spathulate-lageniform to moniliform $\{1\}$, terminal cell *(32-) 52-85(-93) × 4-5.5(-6.5) $\mu \mathrm{m}\{2\},+38-55 \times 2.5-4.2 \mu \mathrm{m}\{1\}$, *6-10 $\mu \mathrm{m}$ wide if inflated, lower cells *(10-)20-32(-49) × 2.7-3.5 $\mu \mathrm{m}\{2\}$; branched only in lower part; terminal cell containing large non-refractive vacuoles and a few very low-refractive globose SCBs; inflated apices laterally covered by a thin, pale ochraceous exudate. Subhymenium light ochre-brown, 20-30 $\mu \mathrm{m}$ thick, of dense textura intricata. Medullary excipulum subhyaline, *indistinctly/tdistinctly gelatinized, of loose to dense t. intricata, individual cells *(40-)75-115 $\times 7-16 \mu \mathrm{m}$, smooth or slightly rough by some granular, pale ochraceous exudate, at base of receptacle $270 \mu \mathrm{m}$ thick, at margin $80 \mu \mathrm{m}$, of dense, horizontal t. porrecta, sharply delimited from ectal excipulum; in stipe of vertical t. porrecta; hyaline stromatic tissue inside seed only observed close to insertion of stipe. Ectal excipulum \pm hyaline, 50-100 $\mu \mathrm{m}$ thick at lower flanks, of thin-walled ( + slightly gelatinized, common walls 1-2 $\mu$ m thick), \pm vertically or often horizontally oriented t. globulosa(-prismatica) from base of receptacle up to mid flanks,

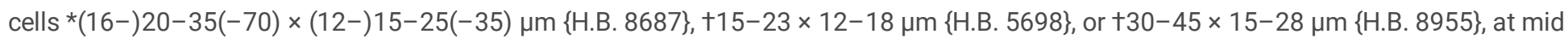
flanks 30-40 $\mu \mathrm{m}$ thick, with ochre-brown exudate, marginal cells *38-70 × 6-10 $\mu \mathrm{m}\{1\}$, hyphoid but terminally \pm strongly inflated; exterior covered by 1-2 layers of *5-10 $\mu \mathrm{m}$ wide hyphae, these sometimes vertically projecting as $1-2$-celled, short-cylindrical, hyaline hairs (†10-22 × 3-5 $\mu \mathrm{m})$; in stipe of subhyaline to pale ochraceous, more basally bright red-brown t. porrecta, cells *28-46 $\times 3-4 \mu \mathrm{m}$, at very base of dark red-brown t. angularis; hairs on stipe scattered to dense, appressed or projecting, subhyaline, $+40-80(-150) \times 3-5 \mu m$, at base light brown, $+9-10.5 \mu \mathrm{m}$ wide, with $0.5-1.3 \mu \mathrm{m}$ thick smooth wall, covered with scattered granules. Rhomboid crystals very scattered to abundant in or on ectal excipulum $\{3\}$, especially at margin, sometimes also in hymenium, abundant in medullary excipulum of basal part of stipe and in stromatic tissue within seed, here forming druses 15-20 $\mu$ m diam. Amyloidity of tissue: subhymenium $\{2\}$ and outer medullary excipulum $\{1\}$ distinctly pale blue (but negative at high concentration), or entire tissue IKI-, even if $\mathrm{KOH}$-pretreated $\{2\}$. - Anamorph: Cultural characteristics: In pure culture on MEA and MMN the ascospores did not germinate. Sori formed mainly on the funiculus; conidiogenous cells not observed; chlamydospores singly, only sometimes in pairs, pale greyish-brown under transmitted light, blackish-brown under reflected light, coarsly warted and with irregular ridges, individual cells $+(8.2-) 8.7-11(-11.8) \times 7.9-10.8 \mu \mathrm{m}$ (without ornamentation) $\{$ H.B. 10206\}, wall 0.7-1 $\mu$ m thick, ornamentation $~ 0.2-0.5 \mu \mathrm{m}$ high; germinating by phialides 7-14 $\times 3-6.5 \mu$ m on which microconidia 2.5-3.5 $\mu$ m diam. are formed in (basipetal) chains \{Vánky 1982\}. Microconidial synanamorph formed on ascospores germinating in senescent apothecia, producing conidia either terminally or rarely laterally, directly on spore wall (sessile), or from small pegs $0.5-1.5 \times 0.5-1.3 \mu \mathrm{m}\{$ H.B. 8687\} or lageniform phialides $+2.5-5 \times 1.5-3 \mu \mathrm{m}\{$ H.B. 5698$\}$; phialoconidia globose to

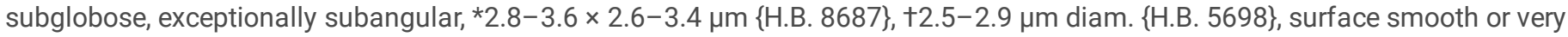
indistinctly rough, CRB-; containing a single eccentrical LB (0.8-)1.2-1.6(-1.8) $\mu \mathrm{m}$ diam. $\{$ H.B. 8687\}.

Habitat: Teleomorph on fallen, present or previous year's, moderately stromatized seeds of Veronica hederifolia agg. $\{11 / 6\}$, seeds $2-2.5$ mm diam., surface always rugose, light to bright grey-brown, distinctly blackened only at a small area around insertion of stipe.

Anamorph: chlamydospores formed apparently on placentae and funiculi of non-stromatized seeds of Veronica hederifolia s.str. \{2/1\} inside the initially closed capsule of living plants. Desiccation tolerance: apothecia dead in all parts after 1 day in the herbarium (except for ascospores); chlamydospores not tested. Phenology: apothecia: X-I, III-V; anamorph: V-VI (BubÁk 1916, SĂvulescu 1957, Zogg 1985, present collections); Altitude: 60-530 m. Geology: on basophilic to calcareous or more acidic soil: Muschelkalk (partly covered by loess), Lettenkeuper (clay), pleisto- \& holocene sand \& gravel and fluviatile sediments.

\begin{tabular}{|c|c|c|c|c|c|c|c|c|c|c|c|c|}
\hline \multicolumn{13}{|c|}{ Phenology of Schroeteria decaisneana } \\
\hline & Jan & Feb & Mar & Apr & May & June & July & Aug & Sept & Oct & Nov & Dec \\
\hline teleomorph & 1 & 0 & 1 & 1 & 1 & 0 & 0 & 0 & 0 & 1 & 4 & 1 \\
\hline anamorph & & & & & 7 & 5 & & & & & & \\
\hline
\end{tabular}

Specimens included (all on Veronica hederifolia agg.). 
Teleomorph (on fallen seeds): Switzerland: Schaffhausen, 7 km NE of Schaffhausen, 1 km ENE of Thayngen, Flüheweg, MTB 8218/1, 530 m, 10.I.1986, P. Blank \& H.O. Baral (H.B. 2981). - Germany: Brandenburg, 25 km NW of Brandenburg, Rathenow, graveyard, 40-50 m, 29.X.1899, W. Kirschstein, vid. V. Kummer (B 70 0100003). - 3 km NE of Luckenwalde, WSW of Woltersdorf, Bürgerbusch, MTB 3845/3, 60 m, 9.V.1999, D. Benkert \& V. Kummer, vid. V. Kummer (D.B., V.K., as Ciboria ploettneriana). - Sachsen-Anhalt, 5.5 km NE of Merseburg, NE of Burgliebenau, Elster-Luppe-Aue, MTB 4638/1, 85 m, 8.III.2009, G. Hensel (G.H. 080309). - Saale-Unstrutgebiet 4.3 km NE of Freyburg, 0.8 km W of Zeuchfeld, above vineyard, MTB 4736/42, 195 m, Muschelkalk (covered by Löss), 14.XI.2007, H. \& U. Richter (U.R., sin. doc.). - ibid., 24.XI.2007, H. \& U. Richter, P. \& S. Rönsch (P.R., ex H.B. 8687, M-0276405). - ibid., 16.XI.2008, P. \& S. Rönsch, U. Richter (P.R., H.B. 8955). - ibid., 29.XI.2009, U. Richter (U.R., A.U. 2273, sin. doc., sq.: ITS/LSU MZ048345). - ibid., 10.XII.2009, U. Richter (U.R., A.U. 2274, WU 43982, sin. doc., sq.: ITS/LSU MZ048346). - Bayern, Unterfranken, 7 km SSW of Schweinfurt, $1.5 \mathrm{~km}$ S of Grafenrheinfeld, near NSG Oberes Holz, Alter Main, MTB 6027/1, 200 m, 26.IV.1994, L.G. Krieglsteiner (L.K., H.B. 5698).

Anamorph (on seeds in capsules of living plants of $V$. hederifolia s.str.): Sachsen-Anhalt, $4.3 \mathrm{~km} \mathrm{NE}$ of Freyburg, $0.8 \mathrm{~km}$ W of Zeuchfeld, above vineyard, MTB 4736/42, 195 m, 13.V.2019, H. \& U. Richter (U.R., V.K. P1656/10, sin. doc.). - ibid., 21.V.2019, H. \& U. Richter (H.B. 10206, J.K. S1346, GLM-F129032, sq.: ITS/LSU MW915644).

Taxonomic remarks: The first collection of the teleomorph of Schroeteria decaisneana was made in 1986 by P. Blank near Schaffhausen (Switzerland) and studied by the first author in the fresh state (PI. 8: 1). The fungus was briefly reported by Baral (1986) as "Ciboria" cf. gemmincola Rehm, because it was erroneously believed to grow on galls of Neuroterus albipes (Cynipidae, Hymenoptera), a gall wasp that inhabits leaves of Quercus in Europe. In fact, oak galls, especially those of the related N. numismalis, resemble seeds of Veronica. In his review of Sclerotiniaceae on oak galls, Palmer (1991) mentioned the above collection by reproducing the first author's drawing, though without personal study. Ciboria gemmincola was described in Wagner (1895) on galls of Cynips gemmae with distinctly smaller, especially narrower spores of $8-9 \times 3.5 \mu \mathrm{m}$.

In the following years the species was repeatedly collected in Sachsen-Anhalt (PI. 7). At this occasion the fungus turned out to grow in fact on seeds of Veronica hederifolia agg. Therefore, the provisional name "Ciboria seminis-veronicae" was used for it, which appears also on the herbarium label of the specimen deposited in $M$ as the intended holotype (H.B. 8687).

Variation: In all collections of Schroeteria decaisneana, from which detailed documentation was made, the paraphyses were cylindrical and apically scarcely inflated. Yet, in one of the large apothecia of a sample from Freyburg (Zeuchfeld, H.B. 8687) they were predominantly strongly inflated and variously shaped (PIs 7, 8: 3a, 11: 1j). The pale blue IKI-reaction of the subhymenium and outer medullary excipulum appears to be variable: it was present in the samples from Schweinfurt and Schaffhausen, but absent in those from Freyburg (no data available for the sample from Merseburg). Variation was also noted in ectal excipular cell size at the lower flanks, being much larger in the samples from Freyburg (H.B. 8687, 8955) compared to Schweinfurt (H.B. 5698) (no data available for those from Schaffhausen and Merseburg). Also the orientation of the cells varied. Finally, crystals were present in the collections from Schaffhausen and Freyburg, but they were not seen in those from Schweinfurt and Merseburg. In the Schweinfurt collection the germinating ascospores were predominantly 1-septate but also non-septate, and often they budded at both ends (PI. 8: $2 \mathrm{~g}$ ), whereas in that from Freyburg they were always non-septate and germinated only at one conidiogenous locus (PI. 8: 3c).

Cultural studies: Microconidia were abundantly produced from ascospores in senescent apothecia after incubation in a moist chamber. When shot on agar medium (MEA), the ascospores did not produce a mycelium even after several weeks of incubation at room temperature. According to studies by Brefeld (1912) and Vánky (1982), fresh chlamydospores germinated in tap water or strongly diluted nutrient solution at room temperature after 1-2 weeks and formed hyphae that abundantly produced phialides and microconidia. After adding concentrated nutrient solution, abundant mycelium developed instead. No attempts have been undertaken in the present study to obtain apothecia from stromatized seeds in a moist box.

Similar species: The study by the first author of a recent collection of Ciboria polygoni-vivipari Eckblad [Sweden, Lapland, Saxnäs, Marsfjället, 950 m, on bulbils of Bistorta vivipara (= Polygonum viviparum), 28.VII.2010, P. Perz, H.B. 9387, Baral ined., see IVV and https://svampe.databasen.org/taxon/11632] revealed some resemblance with the $S$. decaisneana teleomorph, particularly regarding the ascospores containing mostly two polar, medium-sized LBs. However, the spores were distinctly larger $(* 15-19 \times 7.2-7.8 \mu \mathrm{m})$ and contained at least two nuclei, the paraphyses contained many low-refractive VBs in their apex, the ectal excipulum was of textura globulosa, and no crystals were seen. Ciboria seminicola (Kienholz \& E.K. Cash) Hechler [including the questionable C. betulae (Woronin) W.L. White] on fruits of Alnus and Betula differs in somewhat longer and narrower, fusoid, warted ascospores and in asci arising from simple septa without croziers (Baral ined., H.B. 3677, 3682, 5136, 9774, see IVV). 
Ecology: Schroeteria decaisneana was recorded near Freyburg (Zeuchfeld, PI. 12) in a thermophilous deciduous forest with Ulmus minor bordered by Prunus spinosa, near Schweinfurt (Alter Main) in a riverbank forest (Querco-Ulmetum), near Merseburg (Elster-Luppe-Aue) in a riverbank forest with Prunus padus (? Pruno-Fraxinetum), and near Luckenwalde (Bürgerbusch) in a Pruno-Fraxinetum. The distribution of the anamorph of $S$. decaisneana comprises various countries of Europe (Scholz \& Scholz 1988): Austria, former Czechoslovakia, France, Germany, Greece, Hungary, Italy, Poland, Romania, Sweden, Switzerland, and former Yugoslavia.

Schroeteria delastrina (Tul. \& C. Tul.) G. Winter, Rabenh. Krypt.-Fl., Edn. 2 (Leipzig) 1.1: 117 (1881) [1884] - PI. 15

$\equiv$ Geminella delastrina (Tul. \& C. Tul.) J. Schröt., in Rabenh. Fungi Eur. exs. Cent. 14: no. 1376 (1870)

三Schizonella delastrina (Tul. \& C. Tul.) Thirum. \& M.D. Whitehead, Am. J. Bot. 55: 186 (1968)

三 Thecaphora delastrina Tul. \& C. Tul., Annls Sci. Nat., Bot., sér. 3 7: 108 (1847)

= Schroeteria delastrina var. reticulata Cocc., Mém. R. Accad. Sci. Ist. Bologna, Ser. 5 7: 219 (1898)

For a description see Vánky (1982).

Taxonomic remarks: A microscopic documentation of Schroeteria delastrina was done on the sample from Hannover (PI. 15: 4c). Spore size was here evaluated as 7.8-11 $\times$ 7-9 $\mu \mathrm{m}$ (without ornamentation, see Tab. 4), the ornament as $\sim 0.5-1(-2) \mu \mathrm{m}$ high. According to Zogg (1985: 89, pl. 20B figs 1-5) the spore ornament is very different between $S$. delastrina and $S$. decaisneana, with warts and ridges up to $2 \mu \mathrm{m}$ high in the former compared to only $\sim 0.2 \mu \mathrm{m}$ in the latter species.

Ecology: Schroeteria delastrina was reported by earlier workers on different Veronica species, though mainly on Veronica arvensis, the type substrate. Our investigated collections from Germany and Greece were all on this host plant which occurred at the collection sites in different biotops: in Germany in ruderal vegetation at the border of farmland (Kelbra), in mown meadows (Hannover, Thale), and in a Mesobromion grassland (Bad Frankenhausen, Leistadt, Sondershausen), in Greece in an annual vegetation on a raised area on the border of a summer-dry stream bed. The geology was mainly basophilically influenced, the phenology is May-June, in southern Europe March.

The distribution of the anamorph of $S$. delastrina comprises various countries of Europe (Scholz \& Scholz 1988): Austria, Belgium, former Czechoslovakia, Denmark, Finland, France, Germany, Great Britain, Greece, Italy, Netherlands, Portugal, Poland, Romania, Sweden, Switzerland, former Soviet Union, and former Yugoslavia.

Specimens included (all in capsules of living plants of Veronica arvensis).

Anamorph: Germany: Thüringen, Kyffhäuser, $15 \mathrm{~km}$ SE of Nordhausen, 4 km WSW of Kelbra, between Mittelberg and Schloßberg Kleiner Heuweg, MTB 4531/44, 161 m, 28.V.2015, V. Kummer (V.K. P1652-23, sin. doc., sq.: ITS MW915652). - 0.9 km N of Bad Frankenhausen, Schlachtberg, 235 m, MTB 4632/23, 14.VI.2019, V. Kummer (V.K. P1652-26, sq.: ITS/LSU MW915645). - Hainleite, ESE of Sondershausen, N of Jecha, Panzerstraße 1, 185 m, MTB 4631/14, 14.VI.2019, V. Kummer (V.K. P1652-27, sin. doc., sq.: ITS/LSU MW915646). -

Niedersachsen, 5.5 km ENE of Hannover, Groß Buchholz, Roderbruchmarkt, Nobelring, in front of hostel, MTB 3624/22, 55 m, $30 . \mathrm{V} .2011$, J. Kruse (ex J. K. S0045, GLM-F129676). - Rheinland-Pfalz, N of Bad Dürkheim, Leistadt, 230 m, 13.V.2020, J. Kruse (J.K. S0969). - Hessen, Frankfurt/Main, SW airport, nearby Mönchhofdreieck, Flugschneise, 100 m, 24.V.2014, J. Kruse (J. K. S0239). - Darmstadt, Winkelschneise, forest sports park, ruderal area, 11.VI.2016, J. Kruse (J.K. S0604). - 5 km SW of Darmstadt, L3097, Pfungstädter Hausschneise, 105 m, 11.VI.2016, J. Kruse (J.K. S0597) - 11 km NW of Eschwege, Frankershausen, Kripp- und Hielöcher, 270 m, 13.VI.2015, J. Kruse (J.K. S0335). - Nordrhein-Westfalen, Essen-Frohnhausen, Martin-Luther-Straße, 75 m, 31.V.2017, J. Kruse (J. K. S0956) - Sachsen-Anhalt, 11 km SW of Quedlinburg, Thale, Hubertusstraße, "Friedenspark”, 180 m, 9.VI.2017, J. Kruse (J.K. S0969). L208 between Balgstädt and Hirschroda, 2,1 km WNW of Balgstädt, Balgstädter Berge, 24.V.2017, J. Kruse (J.K. S0953). - Berlin, 15 km SE of Berlin, Altglienicke, 50 m, 17.V.2014, V. Kummer ( $\varnothing$ ). - Bayern, ca. 2,4 km W Ibind, Fitzendorfer Wollgraswiesen, 340 m, 20.VI.2020, J. Kruse (ø). - Coburg, 1 km NNW of Gemünda, Heiligenwiesen/Heiligenleite, 310 m, 21.VI.2020, J. Kruse (ø). - Greece: Rhodos, 4 km SW of Malonas, 1.8 km SSE of monastery Kamiri, entrance to zur Scoutljaris gorge, 60 m, 29.III.2011, V. Kummer (V.K. P1652-20).

Schroeteria bornmuelleri Magnus, Mitt. Thür. Bot. Ver., N.F. 28: 64 (1911)

For a description see Vánky (1982).

Specimens included (in capsules of living plants of Veronica rubrifolia). 
Anamorph: Iran: Khorasan, 40 km NE of Mahhad, Gughghi (Gojgi), 1250 m, 11.V.1990, D. Ershad, T. \& K. Vánky (H.U.V. 750 ex TUB, sq.: ITS MW915653; BRIP H.U.V. 14892, 15006, non. vid.).

Schroeteria poeltii Vánky, Mycotaxon 18(2): 326 (1983) - Pls 16-19

Etymology: named after the Austrian lichenologist Josef Poelt (1924-1995) who sent the Hungarian smut fungi specialist Kálmán Vánky (*1930) some samples of the fungus.

Holotype: France, Alpes-Maritimes, Menton, Ste. Agnés, seeds of Veronica cymbalaria, 20.VI.1962, H. Teppner (BRIP H.U.V. 10800, non. vid.).

DESCRIPTION. Teleomorph: Apothecia fresh (1-)1.3-2.5(-3) mm diam., non-gelatinous, disc light ochraceous, slightly concave, finally flat, margin thin, not protruding, \pm smooth, exterior pale ochraceous, very finely pubescent, receptacle at base $0.5-0.75 \mathrm{~mm}$ thick, at margin $0.25-0.35 \mathrm{~mm}$; stipe 5-17 $\times(0.07-) 0.15-0.55 \mathrm{~mm}$, concolorous with receptacle in upper part, darker red-brown in lower part, black-brown at base, overall densely pubescent with rather long hairs; often gradually thinner towards base, flexuous especially in lower part, emerging singly from convex or lateral side of the seed. Asci * $145-160 \times 9.5-10.5(-10.8) \mu \mathrm{m}\{1\},+114-135 \times 7-8.5 \mu \mathrm{m}\{1\}$, protruding $* 5-30 \mu \mathrm{m}$ beyond paraphyses or $(\dagger) \pm$ equalling the paraphyses, with 8 equal-sized spores (in overmature apothecia also unequal-sized), pars sporifera *53-63 $\mu \mathrm{m}$ long, spores obliquely subbiseriate; apex (†) hemispherical to moderately truncate, apical thickening immature or mature $+2-3.8 \mu \mathrm{m}$ thick, apical ring blue in IKI $\{2\}$, euamyloid (BB), of Sclerotinia-type, lower ring strongly blue, upper parts less so; base with short and thick stalk, arising from croziers $\{1\}$. Ascospores * $(9.5-) 10-11(-11.3) \times(5.3-) 5.5-6(-6.3) \mu \mathrm{m}$ $\{1\},+(8.6-) 8.8-10(-10.3) \times 4.7-5(-5.3) \mu \mathrm{m}\{1\}$, ellipsoid (homopolar) or very slightly ovoid (heteropolar), ends rounded to obtuse, \pm equilateral; containing 1(-2) medium-sized LBs close to each end, (1-)1.5-1.8 $\mu \mathrm{m}$ diam. $\{3\}, \mathrm{OCl} 2$, glycogen not observed, with 1 nucleus 3-3.2 $\mu \mathrm{m}$ diam. in centre $\{1\}$; without sheath; overmature spores not observed. Paraphyses apically uninflated to slightly clavate-capitate or sublageniform $\{1\}$, terminal cell $* 57-70 \times 3.5-4.7(-5.2) \mu \mathrm{m}\{1\}$, $\uparrow 3-4.1 \mu \mathrm{m}$ wide, projecting beyond tasci by $5-10 \mu \mathrm{m}$; terminal cell containing large non-refractive vacuoles. Subhymenium light ochre-brown, 25-35 $\mu \mathrm{m}$ thick, of dense textura intricata. Medullary excipulum subhyaline, non-gelatinized, of dense horizontal t. intricata-porrecta, individual cells *(40-)70-130 × 6-11 $\mu \mathrm{m}$, smooth or slightly rough by some granular, pale ochraceous exudate, $100-130 \mu \mathrm{m}$ thick at lower flanks, sharply delimited from ectal excipulum; in stipe of vertical t. porrecta, cells $* 60-90 \times 7-13 \mu \mathrm{m}$. Ectal excipulum 80-90 $\mu \mathrm{m}$ thick at lower flanks, \pm hyaline, at mid flanks $25-35 \mu \mathrm{m}$ thick, brown; of thin-walled, \pm vertically oriented t. globulosa(-prismatica) from base of receptacle up to mid flanks, cells *20-50 $\times 15-30$ $\mu \mathrm{m}\{1\}$; exterior without covering hyphae but with scattered to abundant, protruding, vesiculous or cylindrical to conical, hyaline to brownish, 0-1-septate hair-like cells or hairs *25-35 × 13-15 $\mu \mathrm{m},+18-25 \times 3-10 \mu \mathrm{m}$; in stipe of subhyaline to pale ochraceous $\mathrm{t}$. prismatica-porrecta, cells $+25-40 \times 6-9.5 \mu \mathrm{m}$; hairs on stipe scattered to dense, appressed or projecting, subhyaline to pale brown, $\dagger(22-) 35-195(-258) \times(3-) 4-6(-8) \mu \mathrm{m}$, with 0.3-0.7 $\mu \mathrm{m}$ thick smooth wall, covered with scattered granules, sparsely septate, individual cells $~ 38-85(-140) \mu \mathrm{m}$ long, usually emerging from superficial, swollen basal cells $+15-32 \times 11-17 \mu \mathrm{m}$. Rhomboid crystals scattered in medullary and ectal excipulum, more abundant in stipe. Amyloidity of tissue: subhymenium weakly pale blue (KOH-pretreated) \{1\}. Anamorph: Cultural characteristics: ascospores germination not examined. Sori forming a reddish-brown mass of chlamydospores under reflected light which completely replace the seeds; conidiogenous cells not observed; chlamydospores cohering to form strongly curved (U-shaped) chains of (2-)4-5(-7) spores $\{2\}$, light yellowish-brown under transmitted light, \pm smooth or often with distinct low warts, individual cells *10-11 × 8-10 $\mu \mathrm{m}\{1\},+(5.5-) 6.5-12 \times 6.5-13 \mu \mathrm{m}$ \{type\}, multiguttulate, wall 0.5-0.8 $\mu \mathrm{m}$ thick, ornamentation $\sim 0.3-1(-$ 2) $\mu \mathrm{m}$ high. Microconidial synanamorph (formed on chlamydospores, evaluated from Nagler et al. 1989) hyphoid conidiophores with conidiogenous cells phialidic, cylindrical to lageniform, 8-20 × 3.5-5.8 $\mathrm{mm}$, microconidia \pm globose, *(2.7-)3-3.7(-4) × (2.7-)2.9-3.5(3.8) $\mu \mathrm{m}$, with one eccentrical LB of $1.5-2 \mu \mathrm{m}$ diam.

Habitat: Teleomorph on fallen, previous year's, moderately stromatized seeds of Veronica cymbalaria $\{1\}$, seeds (0.9-)1.7-2.8 mm diam., surface always rugose, light to bright grey-brown or blackish. Anamorph: chlamydospores formed apparently on placentae and funiculi of non-stromatized capsules of $V$. cymbalaria $\{3 / 3\}$ by replacing the seeds inside the initially closed capsule of living plants. Desiccation tolerance: not tested. Phenology: apothecia I; anamorph III, VI. Altitude: 7-650 m. Geology: on acidic and calcareous soil.

Specimens included (all on Veronica cymbalaria).

Teleomorph (on fallen seeds): Spain: Andalucía, Málaga, 14 km S of Ronda, N of Pujerra, arroyo Bollage, 590 m, 4.I.2017, F.J. Valencia, vid. R. Tena (ex C.V.L. 040117, JA-CUSSTA 9523, GLM-F29000, sq.: ITS/LSU MW915648).

Anamorph (on seeds in capsules of living plants): France: Provence-Alpes-Côte-d'Azur, Alpes-Maritimes, 4 km NW of Menton, near Ste.Agnès, 600 m, 20.VI.1962, H. Teppner (BRIP H.U.V. 10800, holotype, GZU 292883 \& 294859 isotypes, doc. vid.). - ibid., 650 m, 
10.VI.1987, K. Vánky (BRIP H.U.V. 13121, topotype, doc. vid.). - Greece: Rhodos, 1.7 km SSW of lalysos, 0.2 km E of Filerimos, monastery park, 212 m, 20.III.2018, J. Kruse \& V. Kummer (V.K. P1675/cymbalaria 1, J.K. S1304, sq...ITS MW915654). - 2.7 km SSE of Masari, SW of Vagies, coastal road, 5 m, 22.III.2018, J. Kruse (J.K. B2278, sq.: ITS/LSU MW915647) - 2.5 km SE of Masari, Charaki, coastal road, former barracks area on the beach, 0 m, 21.III.2018, J. Kruse (J.K. B2279).

Taxonomic remarks: In the teleomorph, Schroeteria poeltii deviates from S. decaisneana merely by slightly smaller asci and ascospores, the latter having their LBs a bit closer to the spore ends, perhaps also in the absence of glycogen in the ascospores and in a tendency to wider excipular cells (Tab. 3). Despite these minor differences, the anamorph sharply differs by smooth, yellowish-brown chlamydospores cohering in strongly curved (U-shaped) chains of (2-)4-7 spores from the other Schroeteria spp. with their warted, greyish-brown chlamydospores cohering in straight chaines of 2-4 spores or detaching as single spores. The exclusive occurrence of $S$. poeltii on $V$. cymbalaria and the remarkable anamorph make any confusion with other species very unlikely.

Nagler et al. (1989) investigated the type of Schroeteria poeltii and a collection of S. delastrina on $V$. arvensis by light and electron microscopical methods. The authors observed microconidia formed endogenously in phialides which emerge either from germ tubes of the chlamydospores or directly from the chlamydospores. Besides, the authors illustrated an unusual case of endogenous maturation of microconidia inside of chlamydospores (fig. 7), which they also observed inside hyphal cells of $S$. delastrina (fig. 9). Problematic is that the scales are wrong in some of their illustrations. In order to achieve reasonable measurements, the scales in figs 6 and 9 should be around $20 \mu \mathrm{m}$ instead of $5 \mu \mathrm{m}$ and that in fig. 7 around $3 \mu \mathrm{m}$ instead of $2 \mu \mathrm{m}$, whereas the scales in figs 12-17 appear to be correct.

In the collection from Filerimos, not all capsules of a given plant individuum were filled with chlamydospores but numerous were with seed formation. However, this varied even on a single shoot of a plant. Whether the seeds are able to germinate has not been tested. This is in contrast to our collections of Schroeteria delastrina on Veronica arvensis where all capsules of a shoot on a plant were either filled with chlamydospores or with seeds, suggesting a systemic infection.

Typification and etymology: Vánky (1983), who investigated the type of S. poeltii, stated that the species was only known from the type locality, where it was collected by H. Teppner in 1962. In a footnote he explained the reason for naming the species S. poeltii: shortly after publication of Vánky's Schroeteria monograph which appeared in 1982, Josef Poelt had sent him a specimen of Teppner's collection. Part of this collection then remained in GZU, whereas the holotype was stated by Vánky to have been deposited at UPS. However, according to Å. Kruys (pers. comm.) the specimen could not be found at UPS. In 1987 Vánky collected a topotype, which Nagler et al. (1989) investigated. In 2013 Vánky gave his entire herbarium to BRIP (Brisbane) where the holotype and also the topotype are listed in the online database.

Ecology: The host plant of Schroeteria poeltii has a (sub)mediterranean distribution and forms urn-shaped seeds similar as in $V$. hederifolia (cyathiform fide Muñoz-Centeno et al. 2006).

The French holotype collection was from a mesomediterranean semihumid site northeast of Monaco in dépt. Alpes-Maritimes. The collecting locality is not fully clear: the rough coordinates $\left(43^{\circ} 47^{\prime} \mathrm{N}, 7^{\circ} 30^{\prime} \mathrm{E}\right)$ given by Vánky (1983) are in a region about $1 \mathrm{~km}$ north of the seaside town Menton and cover a region of about 50-200 m altitude. The given data about altitude (ca. $600 \mathrm{~m}$ ) and site (tract Ste. Agnès, Umgebung von Ste. Agnès) in Vánky (I.c.) and on the handwritten isotype label in GZU (which lacks coordinates), suggest that the collection site was about $4 \mathrm{~km}$ northwest of Menton, i.e., about $3 \mathrm{~km}$ away from the published coordinates.

The Schroeteria poeltii anamorphs from thermomediterranean semihumid Greece were collected at the site Filerimos in an open grove with Quercus coccifera on top of a hill in the monastery park at $212 \mathrm{~m}$ altitude in the north of Rhodos, and near Charaki in a ruderal farmland area with Mercurialis annua etc., a former military area close to coastline at $7 \mathrm{~m}$ altitude in the middle east of Rhodos. The teleomorph from supramediterranean semihumid Spain was from an acidic floodplain forest in Málaga (Andalucía). The apothecia were found on stromatized seeds of Veronica cymbalaria fallen to the ground. The plants grew just above the ground on the vertical area of a schist rock. The floodplain forest consisted of Populus alba and Salix alba, and mediterranean plants such as Quercus faginea and Rubia peregrina, also Lamium flexuosum, Rubus ulmifolius, Dorycnium rectum, Ranunculus ficaria, and Vinca difformis. Outside of the flooded area are large Castanea sativa plantations, the main agricultural product of the local people.

\section{Discussion}

Circumscription of Sclerotiniaceae. Whetzel (1945), who erected the family Sclerotiniaceae, characterized it by apothecia arising from black stromata. He included, besides the above-mentioned 150 species in 28 genera, further ca. 55 more or less saprobic species in six genera, which were later separated by Holst-Jensen et al. (1997b) in the new family Rutstroemiaceae. In phylogenetic analyses of rDNA or

Page $19 / 55$ 
rDNA + protein-coding genes, both families formed together with the small Piceomphale clade the highly supported "Sclerotiniaceae lineage", and this lineage formed with the family Cenangiaceae the strongly supported "Lineage A" or "sclerotinioid clade" (Baral 2016, 2019; Pärtel et al. 2016: fig. 1; Kowalski et al. 2018; Johnston et al. 2019: figs 2, 5). In the latter analysis of 15 concatenated gene regions, this lineage included with less support also Cordieritidaceae and with low support Chlorociboriaceae and Polydesmia.

Holst-Jensen et al. (1997b) defined the family Sclerotiniaceae s.str. by determinate (sclerotial) stromata in or outside the host tissue ("sclerotial stromatal lineage"), and the Rutstroemiaceae by indeterminate stromata formed on the substrate ("substratal stromatal lineage"). Yet, several taxa with a black indeterminate stroma that have been included in Rutstroemiaceae, particularly some members placed in Lanzia and Torrendiella, turned out to belong to other families, mainly Helotiaceae, e.g., species related to Hymenoscyphus fraxineus, the causal agent of the ash dieback disease (Baral \& Bemmann 2014), and species reallocated to the new genus Hymenotorrendiella (Johnston et al. 2014).

Phylogeny within Sclerotiniaceae. Different generic concepts have been developed within the Sclerotiniaceae in the past decades. The available phylogenetic analyses of rDNA (including our analysis in PI. 1) and rarely protein-coding genes suggest heterogeneity of some of the classical genera, such as Ciboria, Monilinia, Schroeteria, and Stromatinia, their species clustering in different clades with often unresolved phylogenetic position. These analyses also raise doubts about the current splitting into small genera, for instance, they question the distinction between Dumontinia, Grovesinia, Sclerotinia s.str., and Stromatinia s.str., which could all be assigned to a single genus Sclerotinia s.I. (PI. 1, S2).

Based on anamorph morphology, heterogeneity of Monilinia was observed by Honey (1936), who subdivided the genus into two sections: Junctoriae (Monilinia s.str., growing on fleshy, edible fruits of domesticated Rosaceae, without intercalating disjunctors of the macroconidial chains) and Disjunctoriae (Monilinia s.l., growing on stromatized fruits of Rosaceae, Ericaceae, Empetraceae, and Pyrolaceae, with intercalating disjunctors). This subdivision was followed by Batra (1988, 1991: 101), who distinguished in 1991 five different groups within Disjunctoriae according to the inhabited host, and Schumacher \& Holst-Jensen (1998), who raised the Disjunctoriae to a new though never validly published genus Franquinia Holst-Jensen \& T. Schumach.

Heterogeneity of Monilinia was confirmed by molecular phylogenetic analyses by Holst-Jensen et al. (1997a: fig. 9, SSU+ITS+LSU; 2004, ITS), Takahashi et al. (2005, ITS), Masuya et al. (2009, ITS), and in the present study (PI. 1), with the conclusion that the genus represents two distinct evolutionary lineages. However, a phylogenetic analysis of three protein-coding genes ( $h s p 60, g 3 p d h, c a l)$ by Andrew et al. (2012) provided evidence for a supported monophyletic clade for Monilinia s.l., suggesting validity of the genus in the sense of Honey (1936), whereby its two sections formed supported sister clades. This analysis also suggests a broad concept of Sclerotinia, because members of Dumontinia (D. tuberosa, D. ulmariae) and Stromatinia s.str. (S. rapulum, S. cepivora) are included with Sclerotinia s.str. in a supported clade with comparatively short branches. Similar problems with generic concepts were addressed by Holst-Jensen et al. (1998), who followed a narrow concept of Sclerotinia: they found that the type species of Grovesinia, G. pyramidalis (= G. moricola), consistently contributed to the paraphyly of Sclerotinia in all of their ITS rDNA analyses, unless one ignores the multicellular diaspores of Grovesinia as a valuable morphological marker and includes Grovesinia in Sclerotinia.

Heterogeneity of Schroeteria in the current generic concept resulted from the distant position of S. poeltii (PI. 1). Although Veronica cymbalaria, the host plant of $S$. poeltii, is closely related to $V$. hederifolia agg. (Muñoz-Centeno et al. 2006), the conidia of the $S$. poeltii anamorph are very different from those of other Schroeteria spp. This and the deviating molecular result appear to justify a separation of S. poeltii at some taxonomic level. In the morphology of the teleomorph, however, S. poeltii can hardly be separated from S. decaisneana, including their stromatized seeds. The specialized occurrence of Schroetria s.str. and S. poeltii on the same host genus Veronica suggests a common ancestor which also grew on Veronica seeds. This consideration makes a generic split of Schroeteria in our opinion premature at the moment. Multigene analyses which include protein-coding genes should be carried out to better understand the phylogenetic position of Schroeteria and in particular S. poeltii, comparable to the study by Andrew et al. (2012), which revealed for Monilinia a supported relationship between the two distant subgroups.

The genetically most heterogeneous genus in our analysis was Ciboria, an assemblage of species without a macroconidial anamorph. This heterogeneity was also seen in analyses of, e.g., Galán et al. (2015: fig. 4, LSU, fig. 5, ITS) and Pärtel et al. (2016: fig. 2, ITS). In two analyses (PI. 1, S2), a supported core clade of Ciboria with two species growing on male catkins was formed, C. caucus (type species, on Salicaceae) and $C$. amentacea (on Betulaceae). Although morphologically very similar to those, $C$. coryli on male Betulaceae catkins was not associated but clustered unsupported with Stromatinia cryptomeriae (PI. 1, S2). Another strongly supported clade was formed by Ciboria americana on Castanea cupules, C. viridifusca on Alnus cones, and Coprotinia minutula on dung, which clustered with medium (PI. 1) or strong (S3) support sister to Pycnopeziza sympodialis. Various other Ciboria spp. clustered in different clades scattered across 
the family. The molecular heterogeneity of Ciboria is in contrast to its high morphological homogeneity. Similar as in Schroeteria and Monilinia, the three Ciboria spp. on catkins are morphologically so similar that they can hardly be conceived to have evolved in two distant lineages.

With the present knowledge, the generic position of Ciboria ploettneriana could not satisfyingly be resolved, neither with morphological nor with molecular methods. In our combined analysis (PI. 1) the species clustered unresolved within the Sclerotiniaceae though close to the type species of Sclerotinia (S. sclerotiorum), Stromatinia (S. rapulum), and Dumontinia (D. tuberosa). The distances in the ITS region and LSU D1-D2 domain to these taxa and other genera (Myriosclerotinia, Botrytis, Kohninia) appear to be too low in order to resolve generic limits. Multigene analyses would probably better resolve phylogenetic lineages in this group.

Because of a high similarity in the teleomorphs, a taxonomically satisfying solution which does not strictly follow monophyletic principles but also includes morphological considerations is very difficult to achieve. Despite its low molecular distance to species of Sclerotinia s.I. (including Dumontinia, Stromatinia s.str., and perhaps Grovesinia) and a characteristic motif in the ITS1 region (see below), we here use the current combination Ciboria ploettneriana instead of Sclerotinia, where it was originally placed, because Sclerotinia and Dumontinia have been characterized by freely formed sclerotia which do not incorporate remnants of host tissue (Kohn 1979: 377-378). Stromatinia forms an indefinite stroma comparable to $C$. ploettneriana and might be a suitable genus for this species. Nevertheless, BLAST search for the ITS region of $C$. ploettneriana yields species of Sclerotinia s.str. as closest match. Placement of S. ploettneriana in this group of genera (Sclerotinia s.I.) is supported by very similar ascospores which contain 2-4 nuclei associated with comparatively small LBs, perhaps also by the lack of a macroconidial state which is only known in Grovesinia. However, VBs in the paraphyses, which are characteristic of Ciboria ploettneriana, have not been seen in other members of Sclerotinia s.l., but are typical of Botrytis (= Botryotinia) (see IVV).

When Buchwald (1949: 165) proposed the combination Ciboria ploettneriana, he did not give arguments for doing so and also did not describe the fungus. Here and in his treatment of Danish Sclerotiniaceae (Buchwald 1947: 240, 255), he distinguished two subgroups within Ciboria: subgenus 'Euciboria Boud.' for species on more or less stromatized catkins of Betulaceae and Salicaceae and subgenus 'Stromatinia Boud.' for species on more or less stromatized seeds of Betulaceae, Fagaceae, and monocots. It must be noted that Buchwald (1947: 309) treated Stromatinia rapulum (type of Stromatinia) as a synonym of Sclerotinia tuberosa. Therefore, Buchwald (1949: 164) suggested to rename subgenus Stromatinia to subgenus Pseudociboria Buchw. (non Pseudociboria Kanouse). In his concept of subgenera, Buchwald followed Boudier (1885: 115) who considered the type of stromatization as taxonomically important and distinguished three subgenera within Ciboria (subgenus Sclerotinia with sclerotia, subgenus Stromatinia with a stroma, and subgenus Ciboria without stromatization). Buchwald accepted Sclerotinia as a distinct genus, and the stromatization in $C$. ploettneriana was obviously the reason why he included this species in Ciboria subgenus Stromatinia (in 1949 named Pseudociboria).

The genus Ciboria has been circumscribed by apothecia emerging from locally stromatized catkins, fruits, leaves, or wood and bark, the lack of both sclerotia and a macroconidial anamorph, an ectal excipulum of non-gelatinized textura globulosa, and by comparatively small, hyaline ascospores with a low lipid content (Spooner 1987, Baral in Baral \& Krieglsteiner 1985). However, generic concepts vary among authors. Based on the first author's personal observations, Ciboria can hardly be distinguished by teleomorph and microconidial anamorph morphology from various other genera of Sclerotiniaceae, such as Botrytis, Scleromitrula (= Ciborinia), and Sclerotinia s.I.

The anamorphs of Sclerotiniaceae. According to Schumacher \& Kohn (1985), nine teleomorph-typified genera of Sclerotiniaceae possess a macroconidial anamorph (Botryotinia, Grovesinia, Monilinia, Ovulinia, Phaeosclerotinia, Pycnopeziza, Seaverinia, Septotinia,

Valdensinia). In the traditional dual nomenclature these anamorphs were treated in separately named anamorph-typified genera, such as Botrytis with a synchronous polyblastic conidiogenesis and Monilia with a monoblastic or sympodial conidiogenesis and conidia in branched acropetal chains.

Phialidic microconidial synanamorphs were observed in many genera of Sclerotiniaceae. They have currently been referred to the anamorph-typified genus Myrioconium, which is characterized by small, \pm globose, hyaline, smooth or sometimes warted conidia. The three sclerotiniaceous genera Coma, Microgloeum, and Mycopappus have been erected for their microconidial anamorphs, but are so far without a known teleomorph.

The conidiophores in the various types of macroconidial anamorphs known in the family are short to long, often branched, hyaline or brown. Conidiogenesis is holoblastic, mono- to polyblastic, sympodial, singly or in acropetal chains. The conidia are globose to ellipsoidfusoid, non-septate, (sub)hyaline, typically smooth (except for Verrucobotrys = Seaverinia, Seifert et al. 2011), rarely cylindrical and 1septate (Septotis $=$ Septotinia, Acarosporium with appendages $=$ Pycnopeziza), or forming complex staurosporous multicellular diaspores (Hinomyces $=$ Grovesinia, Cristulariella $=$ Nervostroma, Valdensia $=$ Valdensinia $)$. It must be noted here that, although the diaspores

Page 21/55 
sharply differ between Grovesinia (pyramidal) and Cristulariella (flattened-spherical), strain CBS 737.68 was erroneously renamed in CBS and GenBank from Cristulariella depraedans to Grovesiniapyramidalis (= G. moricola). Verrucobotrys resembles Botrytis but its conidia are subglobose, pale brown and minutely tuberculate (Whetzel 1945, Seifert et al. 2011) and superficially resemble the thallic chlamydospores of Schroeteria.

In their "Recommendations on generic names competing for use", Johnston et al. (2014) proposed to use the anamorph-typified names Botrytis and Valdensia for the holomorph in replacement of Botryotinia and Valdensinia, respectively. In all the remaining pleomorphic genera the authors proposed to maintain the teleomorph-typified name, with one exception: although they gave recommendations on three of the four above-mentioned microconidial genera, they did not treat the oldest genus Myrioconium as a genus competing with Myriosclerotinia. According to Schumacher \& Kohn (1985), the type species of Myrioconium, M. scirpi, is a synonym of Myrioconiumscirpicola, the anamorph of Myriosclerotinia scirpicola, which in turn is the type species of Myriosclerotinia. Thus, Myrioconium is a synonym of the younger Myriosclerotinia which was introduced by Buchwald (1947) at a time when different names were required for different morphs. Today Myriosclerotinia should be protected as it appears much more often in internet search engines than Myrioconium.

\section{Remarks on the genus Schroeteria}

Schroeteria G. Winter, Rabenh. Krypt.-Fl., Edn 2 (Leipzig) 1.1: 117 (1881) [1884]

三 Geminella J. Schröt., in Rabenh. Fungi Eur. exs. Cent. 14: no. 1376 (1870), nom. illegit., Art. 53.1 (non Geminella Turpin 1828, Chlorophyta)

Etymology: Schroeteria: named after the German mycologist and physician Joseph Schröter (1837-1894); Geminella: after the frequently occurring twin spores in the type species.

Type species: S. delastrina (Tul. \& C. Tul.) G. Winter

Circumscription of the genus. The genus Schroeteria represents a small group of Ascomycetes growing as biotrophic plant parasites on different Veronica spp. (Plantaginaceae, earlier placed in Scrophulariaceae) (Brefeld 1883, 1912; Vánky 1982, 1983, 1994). It is characterized by chlamydospores (resting spores) with an under transmitted light bluish-grey to pale yellowish- or reddish-brown, usually warted epispore. Spore formation is thallic by fragmentation of a richly branched mycelium, from which the spores are formed by division of a "spore mother cell" (Vánky 1982: 159; Scholz \& Scholz 1988: 250) which may be variously curved or spirally twisted (Winter 1876: 148, pl. IV, 1881; see also PI. 21: 6). At maturity the irregularly roundish spores often remain coherent as pairs (twin spores) or threes by showing strong constrictions between the individual spores. In contrast to the typical case, Schroeteriapoeltii mainly forms chlamydospore chains of 2-7 cells by showing only slight constrictions at their septa.

Schroeteria chlamydospores are formed in sori inside the capsules of the host plants where they replace either more or less entirely the seeds (e.g., S. delastrina, S. poeltii) or only placenta, funiculus and hilum by leaving the testa, endosperm and embryo unaffected ( $S$. decaisneana). When the capsules finally burst, the chlamydospores appear to be spread by wind and water. During germination on agar, they form hyaline germ tubes on which phialides arise that produce globose, smooth microconidia (earlier referred to as 'sporidioles' or 'sporidia') with an eccentric oil drop (Brefeld 1883; Vánky 1982, Nagler et al. 1989). Other species earlier placed in the genus Schroeteria lack this kind of phialides and grow on other host genera.

According to Zundel (1953), Kochman \& Majewski (1973), Vánky (1982, 1983, 1994: 456), Scholz \& Scholz (1988), and Nagler et al. (1989), six Schroeteria spp. are now accepted, all forming their chlamydospores on seeds of Veronica: S. banatica Vánky (Veronica austriaca), S. bornmuelleri (V. biloba, V. rubrifolia), S. bremeri Petrak (V. ? triphyllos), S. decaisneana (V. hederifolia agg., after Terrier 1958 also $V$. campylopoda, but see below), S. delastrina ( $V$. acinifolia, $V$. agrestis, $V$. arvensis, $V$. dillenii, V. praecox, $V$. triphyllos, V. verna), and $S$. poeltii (V. cymbalaria). Furthermoore, Gaponenko (1965) reported about a S. delastrina infection on V. campylopoda. Scholz \& Scholz (1988) listed S. banatica as infecting also V. prostrata, based on a record from Romania which is not included in Bontea (1985), and S.banatica and S. delastrina on V. prostrata from Slovakia, according to a report by Vánky (1985). The report of S. delastrina on V. triloba listed in Zundel (1953) was not adopted by Vánky (1982) and Scholz \& Scholz (1988).

Nomenclature. Schroeteria was erected by Winter (1881) as a replacement name (nom. nov.) for Schröter's illegitimate name Geminella. The hitherto cited original publication by Schröter (in Rabenhorst 1870: 137) represents a copy of his shortly before issued herbarium label of Rabenhorst's Fungi Europaei exsiccati, which includes a valid description of the genus including a diagnosis (PI. 20, U. Braun \& K. Bensch pers. comm.). Here, Schröter recognized in Geminella only one species, G. delastrina. Geminella and consequently also

Page 22/55 
Schroeteria are thus typified by G. delastrina. Vánky (1982) incorrectly cited "Geminella Schröter (1869: 5)", being unaware that 1869 was not the year of printing but refers to the reporting year of the publication to which Schröter's article was assigned.

Schröter's article finally appeared in the "Abhandlungen der schlesischen Gesellschaft für vaterländische Kultur, Abtheilung für Naturwissenschaften und Medicin 1869/72" (Schröter 1872), while Rabenhorst (1871: 8-12) gave a summary of the complete work already in the January issue of Hedwigia vol. 10. Schröter (I.c.) added G. foliicola (W. Hausm.) J. Schröt. to the genus (as G. foliicola n. sp. with the reference "Ustilago destruens a foliicola Hauskn. in herb. critt. Ital.", apparently confusing Hausmann and Hausknecht), which grows erumpent on leaves of Carex bigelowii subsp. dacica (Heuff.) T.V. Egorova, published as $C$. rigida Good. Shortly afterwards, however, Magnus (1875) excluded this species from Geminella when he synonymized it with Schizonella melanogramma (DC.) J. Schröt. (as Uredo melanogramma, Ustilaginales). As a consequence, Winter (1881) treated Schroeteria once again with only one species, $S$. delastrina. He mentioned four Veronica spp. as hosts of S. delastrina: V. arvensis (type host of S. delastrina, Tulasne \& Tulasne 1847), $V$. triphyllos, V. praecox, and $V$. hederifolia. The latter indicates that Winter did not differentiate between $S$. delastrina and $S$. decaisneana as suggested later by Boudier (1887, as Geminella). Two species growing on Cissus (Vitaceae), described at the end of the 19th century in Schroeteria because of similar paired spores, were transferred to Mycosyrinx as M. cissi (DC.) Beck and M. arabica (Henn.) Penz. (Vánky 1982), a genus of Urocystidales (Ustilaginomycetes) according to molecular data in GenBank.

\section{History about the phylogenetic placement of the genus Schroeteria.}

Since its description by J. Schröter in Rabenhorst (1870) under the illegitimate name Geminella, the genus has been considered over more than a hundred years as belonging to the smut fungi (Ustilaginales, now Ustilaginomycetes) in the Basidiomycota. Therefore, its darkcoloured warted chlamydospores were often called "teliospores", whereas Brefeld (1912), who pointed out the true relationship with Ascomycota, called them chlamydospores because of their thallic ontogeny that represents a direct transformation of hyphal cells into spores. Vánky $(1982,1983)$ and Nagler et al. (1989) simply named them "spores", whereas Bauer et al. (2001) and Vánky (2008a, b) proposed to reinstate the term teliospores in a wide sense for thick-walled resting spores of plant parasites surviving unfavourable periods, mainly during winter, and not to restrict the term to dicaryotic probasidia of basidiomycetous rusts and smuts. They also redefined the term "smut fungus", i.e., from a taxonomic group to a life strategy and organization, to include non-ustilaginomycetous groups of plant parasites that develop teliospores as organs of dispersal and resistance. Other authors have used the term "false smuts" for such non-ustilaginomycetous fungi, e.g., Tanaka et al. (2008). This usage traces back to Brefeld who applied the German version "Falsche Brandpilze" (Brefeld 1908: 221).

The later ignorance of its true relationship is astonishing, since already Brefeld $(1883,1912)$ mentioned the strong similarity of germ tubes, phialides and microconidia in G. delastrina and G. parvispora (= S. decaisneana) with those of the helotialean genus Sclerotinia, viz. in S.tuberosa (Hedw.) Fuckel, S. sclerotiorum (Lib.) de Bary, and perhaps S. trifoliorum Erikss. (all under the name Peziza, the latter as P. ciborioides), compared to a high dissimilarity to hemibasidia of Ustilaginomycetes. Brefeld was convinced about Schroeteria belonging in relationship of Sclerotinia, e.g., because the microconidia did not germinate, which is typical of Sclerotiniaceae and generally interpreted as an indication that they function as spermatia. He could even verify the formation of sclerotium-like bodies in pure culture after several weeks, but did not succeed in obtaining apothecia (see also Vánky 1982, Nagler et al. 1989). Brefeld also failed to find sclerotia or apothecia at the sites where the infected plants grew (Brefeld 1912: 79). Although Brefeld's observations and conclusions have later widely been recognized, they were only sometimes accepted, particularly by Schellenberg (1911) who listed Schroeteria delastrina among the genera and species to be excluded from the Ustilaginaceae. Also Lindau (1912) accepted Brefeld's opinion by expressing doubts that Schroeteria belongs in the "Ustilagineae", but he preferred to leave it there because of the custom at that time to associate the genus with this family.

Others doubted a relationship with Ascomycota, e.g., Ferdinandsen \& Winge (1914: 4). Thirumalachar \& Whitehead (1968) referred Schroeteria in synonymy with Schizonella J. Schröt. (Ustilaginales) by misinterpreting the observations of Schröter and Brefeld as an untypical case, believing that the microconidia never separate from each other, i.e., the germ tubes convert into "beaded cells". In their studies of S. delastrina (l.c.: fig. 8), these authors observed instead elongate fusoid "secondary sporidia" of $6 \times 2.5 \mu \mathrm{m}$ on septate germ tubes and they concluded that this type of germination is typical of Ustilago spp. Also Vánky (1982), who illustrated the characteristic microconidial synanamorph of Schroeteria in detail and stressed its possible relationship with Ascomycota, still retained the genus in Ustilaginales and referred to the chlamydospores as "teliospores".

Nagler et al. (1989) studied S. delastrina and S. poeltii by cultural and ultrastructural methods. The authors could not obtain sclerotial structures, but they concluded that Schroeteria represents an anamorphic genus of Ascomycota, based on the absence of caryogamy and meiosis, the consistent presence of multinucleate germ tubes, the morphology of the spindle pole bodies, the presence of septal pores

Page 23/55 
with a pore plug and Woronin bodies, and the absence of layering in the cell wall. This opinion then also Vánky (1994) accepted. Nagler et al. (I.c.) doubted Thirumalachar \& Whitehead's (1968) findings of spore germination in S. delastrina as they could never see this type of germination in their studies. Their unusual observation of endogenous maturation of microconidia inside chlamydospores of $S$. poeltii and inside germ tubes of $S$. delastrina (Nagler et al. 1989: figs 7,9 ) requires further attention.

A similar fungus with warted brown spores, though not formed in pairs, is Restilago Vánky with one species, $R$. capensis Vánky growing in capsules of Ischyrolepis capensis (Restoniaceae, Poales). This was shown to be "the second genus of smut fungi of ascomycetous origin" (Vánky 2008a) because of Woronin bodies at the septal pores. Another false smut fungus is Hapalosphaeria deformans (Syd. \& P. Syd.) Syd. It causes stamen blight of blackberry (Rubus ? corylifolii agg., as Rubus dumetorum) and was already stated by Diedicke \& Sydow (1908) as belonging to ascomycetes, but requires further, particularly molecular investigations. Contrary to Schroeteria and Restilago it forms hyaline, smooth phialoconidia inside brown pycnidia in anthers of Rubus. No sequence data of these two genera are known to us. Another false smut is Ustilaginoidea Brefeld, which forms teliospore-like, olive-brown, subglobose, warted chlamydospores (Brefeld 1895: 194 f.). Earlier placed in Ustilago or Tilletia, the two economically important plant parasites of rice (Ustilaginoidea oryzae (Pat.) Bref.) and a bristle grass (Ustilaginoidea setaria Bref.) were shown by Brefeld to produce in culture Claviceps-like ascomata emerging from sclerotia (Brefeld 1896: 103, 1912: pl. III figs 1-15; see also Tanaka et al. 2008). Based on molecular methods, Bischoff et al. (2004) placed Ustilaginoidea in Clavicipitales. Finally, Tanaka et al. (2020) referred four species, which were previously placed in Ustilago and infect ovaries of monocot flowers of the family Commelinaceae, to a new genus Commelinaceomyces in Clavicipitaceae (Sordariomycetes).

\section{Specific nucleotide positions in the rDNA}

Within the core clade of Sclerotiniaceae, no specific nucleotide positions in the ITS region and LSU D1-D2 domain have been found that characterize any of the different genera, such as Botrytis, Elliottinia, Grovesinia, Monilinia s.str., Myriosclerotinia, Ovulinia, Pycnopeziza, Sclerotinia s.l., or Valdensia. Regarding placement of Ciboria ploettneriana, only one position in the middle of ITS1 gives a hint on its generic affiliation: the species shares the motif GGGGYCT ( $\mathrm{Y}=\mathrm{C}$ or $\mathrm{T}$ ) with most species of Sclerotinia s.l., but also with Grovesinia moricola, whereas other species have mostly the motif HGGGCCT ( $\mathrm{H}=\mathrm{A}$ or $\mathrm{C}$ or $\mathrm{T}$ ). The Schroeteria core clade shows some characteristic motifs. In the ITS region, pos. 123 of the $5.8 \mathrm{~S}$ region is $\mathrm{C}$ and pos. 4 of the ITS2 region is G, whereas S. poeltii and other Sclerotiniaceae have T + T, except for Monilinia jezoensis which has T + G. In the LSU D1-D2 domain, Schroeteria decaisneana and S. delastrina have several extraordinary positions. Some of them occur also in Ciborinia erythronii, but none were observed in Ciboria ploettneriana and any other Sclerotiniaceae in GenBank.

\section{Species delimitation within Schroeteria, doubtful measurements of chlamydosporesand microconidia.}

Vánky (1982) treated five species in Schroeteria, which he distinguished by the mature chlamydospores occurring mostly in pairs or threes to fours (S. bremeri, S. delastrina) or mostly single (S. banatica, S. bornmuelleri, S. decaisneana). Species delimitation was further accomplished by spore wall thickness and the kind of spore ornamentation. Chlamydospore size lies in the five species within a similar range of about (7-)8-16(-20) $\mu \mathrm{m}$ diam., which makes spore measurements comparatively useless for species delimitation, considering the high infraspecific, particularly intrapopulational variability observed in each species. For instance, chlamydospore size of $S$. decaisneana varied considerably within a preparation made by us from a single sorus (PI. 14: 2e-k). Vánky (1982) used chlamydospore size in his key, but the given measurements strongly overlap. They clearly refer to single cells, whereas in the older literature it is not always clear whether they mean single cells or twin spores. Vánky (1983) described the morphologically deviating S. poeltii as a sixth species within Schroeteria, characterized by up to 6(-7)-celled, strongly curved (horseshoe-shaped), almost smooth chlamydospores.

Boudier (1887) separated S. decaisneana from S. delastrina owing to slightly smaller, soon single, at first glaucous or bluish-grey, finally grey-black or slate-grey spores born on narrower hyphae, and a different host plant on which it merely attacks the funiculus, leaving the seed and placenta intact. Brefeld (1912: 75) was unaware of S. decaisneana when he proposed the name "Geminella (Schroeteria) parvispora" (a taxon which we here consider a synonym of $S$. decaisneana) for collections on Veronica hederifolia agg. The name Geminella parvispora, which was not listed in databases before November 2020, is mentioned several times in Brefeld's text and in his legend to tab. III fig. 16-17. When first mentioned on p. 75, he cites it as follows (translated from German): "The fungus living on $V$. hederaefolia is the small, single-spored bluish form which produces an easily dispersed spore dust and is here named Geminella (Schroeteria) parvispora". In our opinion, the taxon is to be considered as validly described on p. 75 under the name Geminella parvispora.

Two years later, the valid combination Schroeteriaparvispora was used by Ferdinandsen \& Winge (1914: 4). In the same year also Fischer (1914) published this combination, but that paper appeared later, apparently after September 1914, whereas Ferdinandsen \& Winge's appeared on 17. July 1914. Later, Liro (1938) considered G. parvispora as a synonym of S. decaisneana.

Page 24/55 
Brefeld (1912) characterized Geminella parvispora by small, mostly single, only slightly rough, blueviolet spores that easily get dispersed, in contrast to $S$. delastrina on $V$. triphyllos and $V$. arvensis etc. which has rough-warted, black, double-sized spores that are formed in pairs or sometimes threes. He did not indicate the origin of his samples, but it can be assumed that he collected them during his term in Münster (Nordrhein-Westfalen, Germany) where he worked as a botanist at the university and director of the botanical garden until 1898 (Brefeld 1912: 79). Thereafter he was offered a chair in Breslau where he started to go blind in the same year due to a glaucoma.

Regrettably, Brefeld did not give any measurements of conidia or other elements. When looking at his illustrations (Brefeld 1912: pl. III figs 16 \& 18), it is evident that the individual cells of the chlamydospores of Geminella parvispora are only slightly smaller than those of $G$. delastrina and not "almost half the size" (Brefeld 1912: 75) or, a few lines later, vice versa those of G. delastrina not "more than double" the size of G. parvispora, provided that he compared the diameter of the cells and not their volume. Brefeld referred in this context to "single spores", and as he wrote that the "spores" often remain connected in pairs or threes, it appears that his remark on double-sized spores of G. delastrina cannot refer to the length of twin spores compared to single spores in G. parvispora. On the other hand, some authors used to measure chlamydospores of Schroeteria as an entity, e.g., in his key Ciferri (1938) gave for S. delastrina a spore size of 15-23 $\times$ 8-12 $\mu \mathrm{m}$ (referring to twin spores) and for $S$. decaisneana 10-12 × 8-12 $\mu \mathrm{m}$ (referring to single spores), and also Bubák (1916) measured $S$. delastrina as 20-30 × 12-17 $\mu \mathrm{m}$ regarding twin or sometimes triple spores, and $S$. decaisneana as 7.5-15 $\mu \mathrm{m}$ regarding single spores (see Tabs 4-5).

As a common usage in earlier times, Brefeld (1883: pl. XI fig. 13, pl. XII fig. 14-18; 1912: pl. III figs 16, 18) did not provide scales but only enlargement factors for his detailed illustrations, which were drawn at a $150 \times$ up to $400 \times$ magnification, according to his captions. Our reevaluation of spore size based on the printed books yields values much above the current data of the two species (Tabs 2, 3). Actually, a cell diameter above 17-18 $\mu \mathrm{m}$ appears to have never been reported for chlamydospores of Schroeteria, therefore, the real values of Brefeld's material were probably much lower. The actual average chlamydospore cell sizes of Schroeteriadelastrina and $S$. decaisneana lie in the range of 8-12 $\mu \mathrm{m}$, which is just half of what can be evaluated from Brefeld's sketches of S. delastrina (Tab. 4), whereas his drawing of G. parvispora yields a cell size of about 1.5× larger than the current values (Tab. 5). On the other hand, Brefeld's (1883: pl. VI) illustration of Microbotryum cardui (as Ustilago cardui) yields teliospores of 16-19 $\mu \mathrm{m}$ diam., in good agreement with data given by Vánky (2012) for this species $(15-20 \times 14.5-19 \mu \mathrm{m})$.

Brefeld's observations and drawings were always made from material he cultured in nutrient media rather than from freshly collected specimens. As an example, he described the enormous swelling of the endosporium of a twin spore (Brefeld 1883: 144, pl. XII fig. 17a), which means that spore size evaluated from his drawings needs to be compared with caution with measurements of other authors who usually observed uncultured material. However, spores drawn by him without germ tubes or without emerging endosporium appear also oversized, although they should concur in size with uncultured spores because of an inelastic exosporium.

The presumed error in Brefeld's scale becomes evident when comparing microconidial size among reports of different authors. Surprizingly, also Cocconi's (1898) illustration of $S$. delastrina var. reticulata Cocc. yields double-sized values for chlamydospores (20-26 $\mu \mathrm{m})$ as well as microconidia $(7-8 \mu \mathrm{m})$, according to the stated magnification factor (Tab. 4). We thereby presume that the spore size of 16-20 $\mu \mathrm{m}$ given by Cocconi for twin spores of this variety refers to the diameter of single cells.

Without having examined the type, Ciferri $(1931,1938)$ raised doubts about Cocconi's var. reticulata, which Cocconi $(1898)$ distinguished by a reticulate epispore from the type variety which has a verrucose epispore. Because Cocconi's drawing shows spores with a dense spiny ornament in contrast with the description, and the host plant was seemingly Veronica praecox, on which also $S$. delastrina has been reported, Ciferri concluded that $S$. delastrina var. reticulata is a synonym of $S$. delastrina. Also Vánky (1982) considered Cocconi's description of reticulate spores as an inaccuracy, arguing that the spore surface in Schroeteria is generally verrucose and ribbed (but Vánky figured reticulate spores in S. decaisneana), and he also doubted Cocconi's large spore measurements.

Table 4. Measurements of chlamydospores and microconidia of Schroeteria delastrina (on Veronica arvensis) in the literature.

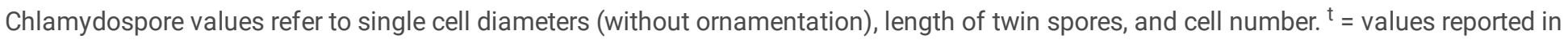
text; $^{s}=$ values gained based on scale or magnification factor of illustration; $\S=$ type of $S$. delastrina var. reticulata, ${ }^{\$}=$ including $S$. decaisneana. Note that Brefeld's and Cocconi's data (highlighted in italics) are about 1.5-2x higher than those of other authors and obviously erroneous. 


\begin{tabular}{|c|c|c|c|c|}
\hline & single cells of chlamydospores $[\mu \mathrm{m}]$ & twin spores & cell number & microconidia $[\mu \mathrm{m}]$ \\
\hline \multirow[t]{2}{*}{ Tulasne \& Tulasne 1847} & $12-14^{t}$ & $16-20^{t}$ & $2(-3)$ & - \\
\hline & $(8.5-) 10-12 \times(4.5-) 6.5-11^{\mathrm{s}}$ & $15-20^{s}$ & & \\
\hline Winter (1876) & $7-9.5 \times 6-8.5^{\mathrm{s}}$ & $16-23^{t}$ & 2 & - \\
\hline Schröter (1877) & $7.7-9.5 \times 6.7-8.5^{\mathrm{s}}$ & $12.5-16.5^{s}$ & $(1-) 2$ & $2.7-4.3^{s}$ \\
\hline Fischer v. Waldheim (1877) $\$$ & $10-13 \times 8-10.5^{t}$ & $?$ & $? 2$ & - \\
\hline Winter (1881) & $9-12^{\mathrm{t}} \times 8-11.5^{\mathrm{s}}$ & $?$ & $2(-3)$ & - \\
\hline Brefeld (1883) & $(12.5-) 16-24(-26) \times(12.3-) 15-21^{\mathrm{s}}$ & $30-40^{5}$ & $(1-) 2$ & $6-7$ \\
\hline Boudier (1887) & $11-15^{\mathrm{t}} / 7-12 \times 6-11^{\mathrm{s}}$ & $16-18.5^{s}$ & $(1-)$ 2-3 & - \\
\hline De Toni (1888) & $8-12^{t}$ & $15-23^{t}$ & $2(-3)$ & - \\
\hline Cocconi (1898) § & $16-20^{t} / 20-26 \times 16.5-23^{s}$ & $37-45^{5}$ & 2 & $7-8^{s}$ \\
\hline Brefeld (1912) & $16.5-26.5 \times(10-) 15-22.5^{\mathrm{s}}$ & $32-45^{s}$ & $(1-)$ 2-3 & - \\
\hline Bubák (1916) & $12-17^{t}$ & $20-30^{t}$ & $2(-3)$ & - \\
\hline Ciferri (1938) & $8-18 \times 8-12^{t}$ & $15-23^{t}$ & $2(-3)$ & - \\
\hline Liro (1938) & $9-13^{t}$ & $?$ & $2(-3)$ & - \\
\hline SĂvulescu (1957) & $(9-) 10-12(-15) \times(8-) 9-12^{t}$ & $\sim 14-21^{\mathrm{s}}$ & $2(-3)$ & - \\
\hline \multirow[t]{2}{*}{ Vánky (1982) } & $8-11(-13.5) \times 8-11(-13)^{t}$ & $18-20^{s}$ & $(1-) 2(-3)$ & $2.7-3.3^{t}$ \\
\hline & $9.5-11 \times 8-10^{s}$ & & & $2.5-3^{s}$ \\
\hline Zogg (1985) & $(8-) 9-12(-13) \times(7-) 8-11(-12)^{t}$ & $?$ & $2(-3)$ & - \\
\hline present study (Hannover) & $7.8-11 \times 7-9$ & $14-17$ & $2(-3)$ & - \\
\hline
\end{tabular}

Table 5. Measurements of chlamydospores and microconidia of Schroeteria decaisneana (on Veronica hederifolia agg.) in the literature. Chlamydospore values refer to single cell diameters (without ornamentation), length of twin spores, and cell number. ${ }^{t}=$ values reported in text; ${ }^{s}=$ values gained based on scale or magnification factor of illustration; $\S=$ type of Geminella parvispora. Note that Brefeld's values (highlighted in italics) are about 1.5-2x higher than those of other authors and obviously erroneous. 


\begin{tabular}{|c|c|c|c|c|}
\hline & single cells of chlamydospores $[\mu \mathrm{m}]$ & twin spores & cell number & microconidia $[\mu \mathrm{m}]$ \\
\hline Boudier (1887) & $10-12 \times 8-12^{\mathrm{t}} / 7-10 \times 7-9.5^{\mathrm{s}}$ & $13.5-15^{s}$ & $1-2$ & - \\
\hline De Toni (1888) & $10-12 \times 8-12^{t}$ & $?$ & $2 \rightarrow 1$ & - \\
\hline Brefeld (1912) § & $14-17 \times 12-15^{t} / 13.5-20 \times 11.2-18.5^{s}$ & $24-278$ & $1(-2)$ & $6-7 s$ \\
\hline Bubák (1916) & $7.5-15^{t}$ & $?$ & $2 \rightarrow 1$ & - \\
\hline Liro (1938) & $7-11 \times 7-11^{t}$ & $?$ & $1(-2)$ & - \\
\hline Ciferri (1938) & $10-12 \times 8-12^{t}$ & $?$ & $2 \rightarrow 1$ & - \\
\hline SĂvulescu (1957) & $9-12(-15) \times(7-) 8-11(-12)^{t}$ & $\sim 14-18(-26)^{\mathrm{s}}$ & $1-2$ & - \\
\hline Vánky (1982) & $\begin{array}{l}7-12(-13) \times 7-11^{\mathrm{t}} \\
9-13 \times 8-11^{\mathrm{s}} / 7.5-11.2 \times 6.5-10.3^{\mathrm{s}}\end{array}$ & $17.5-21^{s}$ & $1-2$ & $\begin{array}{l}2.7-3.3^{t} \\
2.6-3.3^{s}\end{array}$ \\
\hline Zogg (1985) & $(8-) 9-11(-11) \times(7-) 8-11(-12)^{t}$ & $?$ & $1(-2)$ & - \\
\hline present study (Freyburg) & $(8.2-) 8.7-11(-11.8) \times 7.9-10.8$ & $13.3-15(-18.5)$ & $1(-2)$ & *2.8-3.6 × 2.6-3.4 \\
\hline
\end{tabular}

Ecological remarks on Schroeteria decaisneana and Ciboria ploettneriana and their host plant Phenology and life cycle: Kirschstein (1906) collected apothecia on seeds of Veronica hederifolia agg. at first in October 1899 and a second time in April 1905. The first collection was reidentified by us as Schroeteria decaisneana, whereas we selected the second collection as lectotype of Ciboriaploettneriana. Under the assumption that the ascospores infect flowers of other individuals of this plant, Kirschstein was astonished about the occurrence of apothecia in October as he could not find any evidence for a second flowering period of the annual host plant, which generally blooms in central Europe during (February-)March-May(-June) and fruits during April-June.

Indeed, the two species have a different phenology: Schroeteriadecaisneana forms apothecia during November-January, whereas those of Ciboria ploettneriana are found during March-May. However, collections of mature Schroeteriadecaisneana apothecia from three different sites were made during March-May. The occurrence in late autumn suggests that ascospores of $S$. decaisneana do not infect the host's flowers but start their life cycle in another way. The black stroma of $C$. ploettneriana might aid in surviving the frosty wintertime in order to form apothecia next spring, whereas the greyish-brownish stroma of $S$. decaisneana could be an adaptation in surviving the warm and dry summertime in order to form apothecia next autumn.

Observations indicate that mycelia of Schroeteria spp. exist endophytically in the plant from where they grow up to the flowers. According to Brefeld (1912) and Vánky (1982), plants infected by Schroeteria anamorphs do not differ in general appearance from healthy ones. The vegetative mycelium can be found systemically in the intercellular space of the medullary parenchyma of the entire host plant (Winter 1876: 147, pl. IV fig. 15), though sometimes one or more shoots or in some cases only some flowers may remain healthy. It grows through the floral pedicel, placenta and funiculi into the young seeds where the chlamydospores are formed. In S. decaisneana the fungus replaces placenta, funiculus, and hilum (Boudier 1887: 150) or only the funiculus (Bubák 1916: 59) by leaving the seed unaffected although this can no longer germinate, whereas in $S$. delastrina the seeds are entirely absorbed whereas funiculi and placenta remain unaffected (Winter 1876: 148, Boudier I.c.: 151). Winter (1881: 118), who did not distinguish S. decaisneana, wrote that $S$. delastrina infects placentae, funiculi, and the young seeds. The produced spores form a moldy smelling, greyish-brown, greyish-blueviolet, or greyishblack powdery spore mass which in S. decaisneana fills the ventral cavity of each seed and in S. delastrina the entire capsule (Winter 1881, see also Vánky 1982). The spore mass of the infested seeds or capsules is generally called "sorus" following the custom with teliospores of ustilaginomycetous smut fungi. The capsule later tears open to release the spores passively.

Brefeld (1912: 79) was convinced that the chlamydospores do not infect flowers of other plants but germinate in the soil by forming a persistent mycelium that either infects young plants or produces apothecia that infect with their ascospores young seedlings. Brefeld could not detect apothecia associated with Veronica in the field, but he correctly imagined that they develop from the ovaries (Brefeld 1895: 204). He could not know, however, that during teleomorph formation the fungus transforms the seeds into a sclerotium-like stroma.

Hyperparasitism. Owing to the fact that two sclerotiniaceous species grow on the same organ of the same host plant, the possibility should be considered that one species is a hyperparasite on the stroma of the other. Yet, any such evidence is lacking. Schroeteria 
decaisneana as hyperparasite would be in contradiction to the biology of its anamorph which, like anamorphs of other Schroeteria spp., is known as a direct parasite of the plant. Ciboria ploettneriana as hyperparasite would mean that during spring its ascospores attack plants that have been already invaded by $S$. decaisneana. But where do the ascospores of $S$. decaisneana germinate when they are ejected during late autumn and winter?

Similar hypotheses of hyperparasitism have been assumed in some other sclerotiniaceous fungi. For instance, Spooner (1987: 251) thought that Scleromitrula shiraiana could be a hyperparasite on stromata of Ciboria shiraiana, both occurring on fruits of Morus, and he also mentioned other examples of possible hyperparasites, viz. Episclerotium sclerotiorum (as Mitrula) on sclerotia of Sclerotinia trifoliorum, and Episclerotiumsclerotipus (as Mitrula) on sclerotia of Typhula.

Because Ciboriaploettneriana clustered in our phylogenetic analysis near Sclerotinia spp. distant from all investigated Schroeteria spp., it appears improbable that it possesses a Schroeteria-like anamorph. Yet, also Schroeteriapoeltii did not group with the core clade of Schroeteria nor with any other clade in the family, but whether its deviating anamorph is correlated with a deviating biology is unknown.

Microspecies of $V$. hederifolia. The $V$. hederifolia aggregate consists of three microspecies, the mainly southeast European, (sub)mediterranean $V$. triloba and the more temperate $V$. sublobata ( $V$. hederifolia ssp. lucorum) and $V$. hederifolia (ssp. hederifolia). V. sublobata is typical of floodplain forests but appears to occur also at ruderal and agricultural places, whereas $V$. hederifolia is adapted to arable weed vegetation. The latter is considered an allopolyploid (hexaploid) hybrid of the diploid $V$. triloba and tetraploid $V$. sublobata (Fischer 1974, 1985), but the morphological distinction is very difficult. For photos of the three microspecies see https://www.badvoeslau.at/de/lebenswert/umwelt/kalenderblaetter/april-2014.html.

The identification of the microspecies in the present study was complicated by the fact that $V$. hederifolia and $V$. sublobata apparently occurred at the same site. Fallen infected seeds cannot clearly be assigned because of their very similar morphology, thus we refrained from specifying the exact identity of the host plant. Also $C$. ploettneriana and $S$. decaisneana were sometimes observed at the same plot, but it appears unlikely to us that apothecia of the two species prefer different Veronica microspecies. The unequivocal identity of the microspecies as $V$. hederifolia s.str. was established in two anamorph collections of $S$. decaisneana from Zeuchfeld (13. \& 21.V.2019, V.K. P1656-10 and H.B. 10206), yet based on morphological criteria only. It appears probable that some of the teleomorph collections were instead on $V$. sublobata.

Seed morphology and dispersal. The seeds of Veronica hederifolia agg. and $V$. cymbalaria are extraordinary in resembling a collapsed ball (Juan et al. 1994, Muñoz-Centeno et al. 2006). They are called cymbiform (boat-shaped) or cyathiform (urn-shaped) by showing a roundish ventral cavity. Also V. persica seeds have a ventral but more elongated cavity. The mature uninfected seeds usually remain inside the still closed capsules. Their cavity is finally filled with air which aids in the dehiscent capsule being transported by rain. The cavity includes also the elaiosome, a fleshy structure rich in nutrients. The elaiosome attracts ants which thereby transport the seeds with their head. In the case of $V$. hederifolia agg., the elaiosome contains sugars, proteins, Ricinoleic acid and vitamins B1 and C (Bresinsky 1963). Seeds of many other Veronica spp., e.g. V. arvensis, have more elongated, ellipsoid to flattened seeds without a cavity.

Host specificity. Veronica spp. on which Schroeteria spp. have been reported belong to six different subgenera of Veronica, according to Albach et al. (2004a \& b) and Hassan \& Khalik (2014): subgenus Beccabunga includes V. acinifolia, subgenus ChamaedrysV. arvensis, V. dillenii and $V$. verna, subgenus CochlidiospermaV. hederifolia and V. cymbalaria, subgenus PocillaV. agrestis, V. biloba, V. campylopoda and $V$. rubrifolia, subgenus Pellidosperma V. praecox and V. triphyllos, and subgenus Pentasepalae V. austriaca and V. prostrata.

The here reported teleomorph states of Ciboriaploettneriana and Schroeteriadecaisneana were exclusively found on seeds of Veronica hederifolia agg. Also the $S$. decaisneana anamorph has exclusively been reported in the literature on $V$. hederifolia agg., except for Terrier (1958) who believed to have found it on seeds of $V$. campylopoda received from Yerevan (Armenia). We have some doubts about this, because $V$. campylopoda belongs to another subgenus of Veronica with a clearly different seed morphology. The present reexamination of Terrier's specimen in NEU verified the host species but raised doubts about the fungus, which deviated from $S$. decaisneana by slightly larger chlamydospores of $+\left(9.5^{-}\right) 10-12 \mu \mathrm{m}$ diam. which never cohered in pairs, and with a higher ornamentation (0.3-0.5 $\left.\mu \mathrm{m}\right)$ of more distinct ridges that form an incomplete net (see IVV). The few known collections of Schroeteriapoeltii were all on V.cymbalaria, including the here reported teleomorph (the host of the teleomorph being determined morphologically and by an ITS sequence). S. delastrina was reported from no less than eight different Veronica spp., though mostly from V. arvensis. Particularly $S$. delastrina should be investigated in the future for a possible molecular heterogeneity regarding its broad host spectrum.

\section{Declarations}

Page 28/55 
Funding: None.

Conflicts of interest/Competing interests The authors declare that they have no conflict of interest.

Availability of data The sequences generated in this study are available in the NCBI GenBank (https://www.ncbi.nlm.nih.gov) under the accession numbers given in Tab. 1.

Code availability: Not applicable.

Ethics approval: Not applicable.

Consent to participate: Not applicable.

Consent for publication: Not applicable.

Author's contributions: H.O. Baral made the main morphological evaluation and worked on the taxonomical conclusions, wrote text and tables, arranged most of the plates, and made the molecular analyses and illustration. P. Rönsch and U. Richter wrote a German draft about their observations on the teleomorph of Ciboria ploettneriana and Schroeteria decaisneana. H.O. Baral, P. Rönsch, and G. Hensel documented some of these collections by drawings and/or photographs. W. Huth studied and identified cultured apothecia and supplied data about the ecology of the two species. A. Urban obtained sequences from the teleomorphs of these species and some other Sclerotiniaceae, and J. Kruse from anamorphs of Schroeteria spp. and the teleomorph of S. poeltii. F.J. Valencia documented the teleomorph of S. poeltii and arranged the plate. Martin Bemmann contributed variously regarding literature reports and particularly with his hypothesis of an anamorph-teleomorph connection in Schroeteria decaisneana. V. Kummer reexamined and documented original material of Kirschstein's collections in B, also Terrier's anamorph specimen on Veronica campylopoda in NEU by verifying the identity of the host plant.

Acknowledgements. We want to thank Gunnar Hensel, Lothar Krieglsteiner, Matthias Reul and Torsten Richter for collecting apothecia and/or sending us their documentations, and Manfred Huth for culturing infected seeds. Konstanze Bensch (München) and Uwe Braun (Halle) is thanked for supplying a photo of Schröter's herbarium label of Geminella delastrina and François Valade for a calibrated copy of Boudier's illustration of $G$. delastrina and $G$. decaisneana. We thank Robert Lücking for sending Kirschstein's specimens from B and Jason Grant for those of Terrier from NEU. Thomas Laessøe is thanked for supplying the paper of Buchwald. We are grateful to the members of the Mandragora de Ronda naturalist group for their help in collecting and obtaining data for the Schroeteria poeltii teleomorph and for identification of the associated plants and geology. Finally, D. Haelewaters is thanked for calculating a ML analysis with IQ-tree for comparison.

\section{References}

Albach DC, Martínez-Ortega MM, Fischer MA, Chase MW (2004a) Evolution of Veroniceae: A phylogenetic perspective. Ann Missouri Bot Gard 91:275-302

Albach DC, Martínez-Ortega MM, Fischer MA, Chase MW (2004b) A new classification of the tribe Veroniceae - problems and a possible solution. Taxon 53:429-452

Andrew M, Barua R, Short SM, Kohn LM (2012) Evidence for a common toolbox based on necrotrophy in a fungal lineage spanning necrotrophs, biotrophs, endophytes, host generalists and specialists. PLoS ONE 7(1):e29943 -

https://doi.org/10.1371/journal.pone.0029943

Baral HO (1986) Beilage zum Beiheft 6, Z Mykol [typoskript] - http://www.in-vivo-veritas.de/

Baral HO (1987) Der Apikalapparat der Helotiales. Eine lichtmikroskopische Studie über Arten mit Amyloidring. Z Mykol 53:119-136

Baral HO (1992) Vital versus herbarium taxonomy: morphological differences between living and dead cells of ascomycetes, and their taxonomic implications. Mycotaxon 44:333-390

Baral HO (2016) Inoperculate discomycetes. In: Jaklitsch W, Baral HO, Lücking R, Lumbsch HT, Frey W (eds) Syllabus of plant families: A. Engler's Syllabus der Pflanzenfamilien, part 1/2. Borntraeger, Stuttgart, pp 157-205

Page 29/55 
Baral HO (2019, '2017') Pseudolanzia piceetorum gen. et sp. nov. (Rutstroemiaceae, Helotiales) from fallen Picea abies needles in Mecklenburg-Vorpommern (Germany) Mycol Monten 20:151-166

Baral HO, Bemmann M (2014) Hymenoscyphus fraxineus vs. Hymenoscyphus albidus - A comparative light microscopic study on the causal agent of European ash dieback and related foliicolous, stroma-forming species. Mycology 5(4):228-290 https://doi.org/10.1080/21501203.2014.963720

Baral HO, Haelewaters D (2015) Rommelaarsia flavovirens gen. et sp. nov. (Helotiales), a new discomycete on Equisetum with a peculiar asexual state. Ascomycete.org 7:321-330

Batra LR (1988) Disjunctors in Monilinia (Discomycetidae: Sclerotiniaceae) and their significance in classification. Mycologia 80(5):660664

Batra LR (1991) World species of Monilinia (Fungi): Their ecology, biosystematics and control. Mycologia Memoirs 16:1-246

Bauer R, Begerow D, Oberwinkler F, Piepenbring M, Berbee ML (2001) Ustilaginomycetes. In: McLaughlin DJ et al. (eds) The Mycota 7B. Systematics and evolution. Springer, Berlin, pp 57-83

Benkert D (2005) Die Pilze des Späth-Arboretums in Berlin-Baumschulenweg (zweite, korrigierte und ergänzte Version). Verh Bot Ver Berlin Brandenburg 138:47-82

Bischoff JF, Sullivan RF, Kjer KM, White Jr JF (2004) Phylogenetic placement of the anamorphic tribe Ustilaginoideae (Hypocreales, Ascomycota). Mycologia 96(5):1088-1094

Bontea V (1985) Ciuperci parazite si saprofite din România. Volume I. Editura Academiei Republicii socialiste România, Bucuresti

Boudier É (1885) Nouvelle classification naturelle des discomycètes charnus. Bull Soc Mycol France 1:91-120

Boudier É (1887) Champignons nouveaux rares ou peu connus de France. Bull Soc Mycol France 3(2):145-155, pl. XIII-XVI

Brefeld O (1883) Botanische Untersuchungen über Hefenpilze V. Brandpilze I (Ustilagineen). Arthur Felix, Leipzig

Brefeld O (1895) Untersuchungen aus dem Gesamtgebiete der Mykologie XII: Hemibasidii, Brandpilze III. Heinrich Schöningh, Münster

Brefeld O (1896) Der Reis-Brand und der Setaria-Brand, die Entwicklungsglieder neuer Mutterkornpilze. Bot CentralbI LXV(4):97-108

Brefeld O (1908) Untersuchungen aus dem Gesamtgebiete der Mykologie XIV: Die Kultur der Pilze. Heinrich Schöningh, Münster

Brefeld O (1912) Untersuchungen aus dem Gesamtgebiete der Mykologie XV: Die Brandpilze und die Brandkrankheiten V. Heinrich Schöningh, Münster

Bresinsky A (1963) Bau, Entwicklungsgeschichte und Inhaltsstoffe der Elaiosomen. Studien zur myrmekochoren Verbreitung von Samen und Früchten (Bibliotheca Botanica 126). Schweizerbart, Stuttgart

Bubák F (1916) Die Pilze Böhmens. II. Theil Brandpilze (Hemibasidii). Řivnáč, Prag

Buchwald NF (1947) Sclerotiniaceae Daniae. I. Taxonomy of the Sclerotiniaceae. Friesia 3(4):235-330

Buchwald NF (1949) Studies in the Sclerotiniaceae. I. Taxonomy of the Sclerotiniaceae. K Vet Landbohøjsk Aarsskr 43:75-191

Chatin J (1874) Études sur le développement de l'ovule et de la graine dans les Scrofularinées, les Solanacées, les Borraginées et les Labiées. Ann Sci Nat, Bot 5, ser. XIX:5-107

Cho SE, Park JH, Hong SH, Shin HD (2013) First Report of Zonate Leaf Spot Caused by Hinomyces moricola on Japanese Hop in Korea. Plant Dis 97(8), 1117

Cho SE, Park JH, Choi YJ, Lee SH, Lee CK, Shin HD (2017) Occurrence of leaf spot caused by Cristulariella depraedans on Acer ginnala. For. Pathol. 47(1), e12302

Ciferri R (1931) Quinta contribuzione allo studio degli Ustilaginales. Ann Mycol 29(1-2):1-74

Page $30 / 55$ 
Ciferri R (1938) Ustilaginales. Tilletiaceae, Graphiolaceae, Ustilaginaceae (Flora Italica Cryptogama I: Fungi, fasc. 17). Cappelli, Rocca S. Casciano

Cocconi G (1898) Osservazioni e ricerche sopra una nuova forma di Schroeteria Winth. Rend Accad Sci Inst Bologna NS II:210-221

Derbyshire M, Denton-Giles M, Hegedus D, Seifbarghy S, Rollins J, van Kan J, Seidl MF, Faino L, Mbengue M, Navaud O, Raffaele S, Hammond-Kosack K, Heard S, Oliver R (2017) The complete genome sequence of the phytopathogenic fungus Sclerotinia sclerotiorum reveals insights into the genome architecture of broad host range pathogens. Genome Biol Evol 9(3):593-618. doi: 10.1093/gbe/evx030

De-Toni JB (1888) Sylloge Ustilaginearum et Uredinearum omnium hucusque cognitarum. In: Saccardo PA (ed) Sylloge fungorum VII (2), Patavii, pp 449-882 + XXXI-LIX

Diedicke H, Sydow H (1908) Über Paepalopsis deformans Syd. Ann Mycol 6(4):301-305

Ferdinandsen CCF, Winge $\varnothing$ (1914) Studies in the genus Entorrhiza C. Weber. Dan bot ark 2(1):1-14

Fischer de Waldheim A (1877) Aperçu systématique des Ustilaginées. Leurs plantes nourricières et la localisation de leurs spores. Lahure, Paris

Fischer E (1914) Pilze (incl. Flechten). Ber Schweiz Bot Ges 23:32-48

Fischer MA (1974) Veronica hederifolia agg. in Mitteleuropa. Gött Florist Rundbr 8:95-98

Fischer MA (1985, '1984') Zur Chorologie und Systematik der Veronica hederifolia - Gruppe in Jugoslawien. Akad Nauk Umjetn Bosne Herceg Radovi 76, Odj Prir Mat N 23:55-77

Galán R, Checa J, Blanco MN, Platas G, Tena R, Tello S, Hermosilla CE, Jaklitsch WM, Voglmayr H (2015) Taxonomic position of the genus Bicornispora and the appearance of a new species Bicornispora seditiosa. Mycologia 107(4):793-807 - https://doi.org/10.3852/14-245

Gaponenko NI (1965) Obzor gribov Bucharskoj oblasti (Overview of the mushrooms in the Bukhara region). Izd. "Fan", Taškent, 114 pp

Gardes M, Bruns TD (1993) ITS primers with enhanced specificity for basidiomycetes - application to the identification of mycorrhizae and rusts. Molecular Ecology 2:113-118

Han JG, Hosoya T, Sung GH, Shin HD (2014) Phylogenetic reassessment of Hyaloscyphaceae sensu lato (Helotiales, Leotiomycetes) based on multigene analyses. Fungal Biol 118(2):150-167

Harada Y, Nakao S, Sasaki M, Sasaki Y, Ichihashi Y, Sano T (2004) Monilia mumecola, a new brown rot fungus on Prunus mume in Japan. J Gen Plant Pathol 70:297-307

Hassan NM, Khalik KNA (2014). Systematic significance of seed morphology in the genus Veronica (Plantaginaceae), with special reference to the Egyptian taxa. J Syst Evol 52(2):215-230

Hein B, Gerhardt E (1981) Die nomenklatorischen Typen zu Kirschsteins Namen von Gattungen, Arten und subspezifischen Taxa im Pilzherbar des Botanischen Museums Berlin-Dahlem. Willdenowia 11:123-163

Holst-Jensen A, Kohn LM, Jakobsen KS, Schumacher T (1997a) Molecular phylogeny and evolution of Monilinia (Sclerotiniaceae) based on coding and noncoding rDNA sequences. Am J Bot 84(5):686-701

Holst-Jensen A, Kohn LM, Schumacher T (1997b) Nuclear rDNA phylogeny of the Sclerotiniaceae. Mycologia 89:885-899

Holst-Jensen A, Vage M, Schumacher T (1998) An approximation to the phylogeny of Sclerotinia and related genera. Nordic J Bot 18:705-719

Holst-Jensen A, Vrålstad T, Schumacher T (2004) Kohninia linnaeicola, a new species of the Sclerotiniaceae pathogenic to Linnaea borealis. Mycologia 96:135-142

Honey, EE (1936) North American species of Monilinia. I. Occurrence, grouping and life-histories. Am J Bot 23(2):100-106 
Hong D, Fischer MA (1998) 38. Veronica Linnaeus, Sp. PI. 1: 9. 1753. In: Wu ZY, Raven PH (eds) Flora of China. Vol. 18 (Scrophulariaceae through Gesneriaceae). Science Press, Beijing, and Missouri Botanical Garden Press, St. Louis. 450 pp -

http://flora.huh.harvard.edu/china/mss/volume18/SCROPHULARIACEAE.published.pdf. Accessed 19 Feb. 2021

Hu J-h, Cai Y-x, Zhou S-j, Zhang J-c, Zhang H-I,Chen Y-b, Li P-m, Ying G-m (2011) Diversity of Mulberry Sclerotiniose Pathogen and ITS Analysis. J Ningbo Univ 24:20-23

Huth W (2009) Ascomycetes. In: Täglich U (ed) Pilzflora von Sachsen-Anhalt (Ascomyceten, Basidiomyceten, Aquatische Hyphomyceten). Leibniz-Institut für Pflanzenbiochemie, Halle (Saale), pp 1-718

Jäger EJ (Ed.) (2017) Rothmaler - Exkursionsflora von Deutschland. Gefäßpflanzen: Grundband. 21st. ed. Spektrum Verlag, Berlin und Heidelberg

Jahn R, Schönfelder P (1995) Exkursionsflora für Kreta. Verlag Eugen Ulmer, Stuttgart

Johnston PR, Seifert KA, Stone JK, Rossman AY, Marvanová L (2014) Recommendations on generic names competing for use in Leotiomycetes (Ascomycota). IMA Fungus 5(1):91-120 - https://doi.org/10.5598/imafungus.2014.05.01.11

Johnston PR, Park D, Baral HO, Galán R, Platas G, Tena R (2014) The phylogenetic relationships of Torrendiella and Hymenotorrendiella gen. nov. within the Leotiomycetes. Phytotaxa 177(1):1-25 - https://doi.org/10.11646/phytotaxa.177.1.1

Johnston PR, Quijada L, Smith CA, Baral HO, Hosoya T, Baschien C, Pärtel K, Zhuang WY, Haelewaters D, Park D, Carl S, López-Giráldez F, Wang Z, Townsend JP (2019) A multigene phylogeny toward a new phylogenetic classification of Leotiomycetes. IMA Fungus 10:1-22 https://doi.org/10.1186/s43008-019-0002-x

Juan R, Pastor J, Fernandez I (1994) Seed morphology in Veronica L. (Scrophulariaceae) from south-west Spain. Bot J Linn Soc 115:133143

Kirschstein W (1906) Neue märkische Ascomyceten. Verh Bot Ver Prov Brandenbg 48:39-61

Kochman J, Majewski T (1973) Głowniowe (Ustilaginales) - Podstawczaki (Basidiomycetes). In Kochman J, Skirgiello A (eds) Flora Polska. Rośliny zarodnikowe Polski i ziem ościennych. Grzyby. 5. Państwowe Wydawnictwo Naukowe, Warszawa-Kraków

Kohn LM (1979) A monographic revision of the genus Sclerotinia. Mycotaxon 9(2):365-444

Kowalski T, Boroń P, Bartnik C, Rossa R (2018) Morphological and molecular characterization of Leptomelanconiumallescheri associated with necrotic lesions on Pinus mugo needles in the Polish Tatra Mountains. For Pathol 48:e12420 - https://doi.org/10.1111/efp.12420

Kreisel H (2011) Pilze von Mecklenburg-Vorpommern. Arteninventar, Habitatbindung, Dynamik. Weissdorn-Verlag, Jena

Kummer V (2010) Ein kurzer Abriss zur Geschichte der floristischen Kryptogamenforschung in Berlin und Brandenburg bis zur Mitte des 20. Jahrhunderts. Verh Bot Ver Berlin Brandenbg 143:53-78

Lindau G (1912) Hemibasidii (Ustilagineae). In: Kryptogamenflora der Mark Brandenburg Va, Pilze III. Borntraeger, Leipzig, pp 1-68

Liro JI (1938) Die Ustilagineen Finnlands II. Ann Acad Sci Fenn, Ser A 42: I-X + 1-720

Magnus P (1875) Mykologische Mittheilungen. Hedwigia 14(2):17-21

Masuya H, Kusunoki M, Kosaka H, Aikawa T (2009) Haradamyces foliicola anam. gen. et sp. nov., a cause of zonate leaf blight disease in Cornus florida in Japan. Mycol Res 113:173-181

Muñoz-Centeno LM, Albach DC, Sánchez-Agudo JA, Montserrat Martínez-Ortega M (2006) Systematic significance of seed morphology in Veronica (Plantaginaceae): A phylogenetic perspective. Ann Bot 98:335-350

Nagler A, Bauer R, Berbee M, Vánky K, Oberwinkler F (1989) Light and electron microscopic studies of Schroeteria delastrina and S. poeltii. Mycologia 81(6):884-895 
Pärtel K, Baral HO, Tamm H, Põldmaa K (2016) Evidence for the polyphyly of Encoelia and Encoelioideae with reconsideration of respective families in Leotiomycetes. Fungal Divers 82:183-219

Palmer JT (1991) Sclerotiniaceous cup fungi on oak galls. Cecidol 5(2):31-44

Park JH, Cho SE, Lee SH, Shin HD (2013) First report of frosty mildew on Salix koreensis caused by Mycopappus alni in Korea. J Phytopath 161:866-869

Parolly G, Rohwer JG (eds) (2019) Schmeil-Fitschen. Die Flora von Deutschland und angrenzender Länder. 97th edn. Quelle \& Meyer, Wiebelsheim

Rabenhorst L (1870) Fungi Europaei exsiccati Cent. XIV. Hedwigia 9(9):136-138

Rabenhorst L [as L.R.] (1871) Repertorium. Dr. J. Schröter, die Brand- und Rostpilze Schlesiens. Hedwigia 10(1):8-12

Rehm H (1905) Ascomycetes exs. Fasc. 35. Ann Mycol 3:409-417

SĂvulescu T (1957) Ustilaginalele din Republica Populară Romînă. 2 vols. Editura Academiei Republicii Populare Romîne, Bucureşti Schellenberg HC (1911) Die Brandpilze der Schweiz (Beiträge zur Kryptogamenflora der Schweiz III, H. 2). Wyss, Bern

Scholz H, Scholz I (1988) Die Brandpilze Deutschlands (Ustilaginales). Englera 8:1-691

Schröter J (1872, "1869") Die Brand- und Rostpilze Schlesiens. Abh Schles Ges vaterl Cult, II. Abt, Nat Med 1869-1872:1-31

Schröter J (1877) Bemerkungen und Beobachtungen über einige Ustilagineen. In: Cohn F (ed) Beiträge zur Biologie der Pflanzen 2(3). Kern's Verlag, Breslau, pp 349-383, pl XII

Schumacher T, Kohn LM (1985) A monographic revision of the genus Myriosclerotinia. Can J Bot 63:1610-1640

Schumacher T, Holst-Jensen A (1998) The genus Franquinia Holst-Jensen \& T. Schumach. ined. -

https://web.archive.org/web/20080312082734/http://biologi.uio.no/bot/ascomycetes/Taxa/Franquinia.html. Accessed 25 July 2020

Seifert K, Morgan-Jones G, Gams W, Kendrick B (2011) The genera of hyphomycetes (CBS Biodiversity Series 9). Centraalbureau voor Schimmelcultures, Utrecht

Spooner BM (1987) Helotiales of Australasia: Geoglossaceae, Orbiliaceae, Sclerotiniaceae, Hyaloscyphaceae (Bibl Mycol 116). Cramer, Berlin

Stafleu FA, Cowan RS (1985) Taxonomic literature, a selective guide to botanical publications and collections with dates, commentaries and types, Volume V: Sal-Ste, 2nd edn. Bohn, Scheltema \& Holkema, Utrecht/Antwerpen

Takahashi Y, Ichihashi Y, Sano T (2005) Monilinia jezoensis sp. nov. in the Sclerotiniaceae, causing leaf blight and mummy fruit disease of Rhododendron kaempferi in Hokkaido, northern Japan. Mycoscience 46:106-109 - https://doi.org/10.1007/s10267-004-0219-3

Tanaka E, Ashizawa T, Sonoda R, Tanaka C (2008) Villosiclava virens gen. nov., comb. nov., teleomorph of Ustilaginoidea virens, the causal agent of rice false smut. Mycotaxon 106:491-501

Tanaka E, Shrestha B, Shivas RG (2020) Commelinaceomyces, gen. nov., for four clavicipitaceous species misplaced in Ustilago that infect Commelinaceae. Mycologia 112(3):649-660 - https://doi.org/10.1080/00275514.2020.1745524

Terrier C (1958) Veronica campylopoda Bois., hôte nouveau de Schroeteria decaisneana (Boud.) De Toni. Bull Soc Bot Suisse 68:50-53

The Plant List (2020) A working list of all plant species - http://www.theplantlist.org. Accessed 28 April 2020

Thirumalachar MJ, Whitehead MD (1968) Notes on the smut genera Entorrhiza and Schroeteria. Am J Bot 55(2):183-186

Tulasne L-R (1849) Études d’embryogénie végétale. Ann Sci Nat, Bot 3. ser. XII:26-137

Tulasne L-R, Tulasne C (1847) Mémoire sur les Ustilaginées comparées aux Urédinées. Ann Sci Nat, Bot 7:12-126

Page $33 / 55$ 
Vánky K (1982, '1981') The genus Schroeteria Winter (Ustilaginales). Sydowia 34:157-166

Vánky K (1983) Ten new species of Ustinaginales. Mycotaxon 18(2):319-336

Vánky K (1985) Carpathian Ustilaginales. Symb Bot Upsal 24(2):1-309

Vánky K (1994) European smut fungi. G. Fischer, Stuttgart

Vánky K (2008a) Restilago capensis gen. et sp. nov., an ascomycetous smut fungus. Mycol Balc 5:69-72

Vánky K (2008b) Smut fungi (Basidiomycota p.p., Ascomycota p.p.) of the world. Novelties, selected examples, trends. Acta Microbiol Immunol Hung 55(2):91-109 - https://doi.org/10.1556/AMicr.55.2008.2.2

Vánky K (2012) Smut fungi of the world. APS Press, St. Paul

Verkley GJM (1993) Ultrastructure of the ascus apical apparatus in ten species of Sclerotiniaceae. Mycol Res 97(2):179-194

Vilgalys R (1988) Genetic relatedness among anastomosis groups in Rhizoctonia as measured by DNA/DNA hybridization.

Phytopathology 78:698-702

Vilgalys R, Hester M (1990) Rapid genetic identification and mapping of enzymatically amplified ribosomal DNA from several Cryptococcus species. Journal of Bacteriology, 172(8):4238-4246.

Vu D, Groenewald M, de Vries M, Gehrmann T, Stielow B, Eberhardt U, Al-Hatmi A, Groenewald JZ, Cardinali G,

Houbraken J, Boekhout T, Crous PW, Robert V, Verkley GJM (2019) Large-scale generation and analysis of filamentous fungal DNA barcodes boosts coverage for kingdom fungi and reveals thresholds for fungal species and higher taxon delimitation. Stud Mycol 92'135154

Wagner G (1895) Mycologische Ausflüge im Gebiete des großen Winterberges in der Sächs. Schweiz. Hedwigia 34(4):210-213

Whetzel HH (1945) A synopsis of the genera and species of the Sclerotiniaceae, a family of stromatic inoperculate discomycetes. Mycologia 37:648-714

White TJ, Bruns T, Lee S, Taylor J et al. (1990) Amplification and direct sequencing of fungal ribosomal RNA genes for phylogenetics. In: Innis, M.A., Gelfand, D.H., Sninsky, J.J. and White, T.J., Eds., PCR Protocols. A guide to methods and applications, Academic Press, San Diego, 315-322 - http://dx.doi.org/10.1016/b978-0-12-372180-8.50042-1

Winter G (1876) Einige Notizen über die Familie der Ustilagineen. Flora 59(10):145-152, (11):161-172, pl IV-VII

Winter G (1881) [1884] Die Pilze Deutschlands, Oesterreichs und der Schweiz. I. Abteilung: Schizomyceten, Saccharomyceten und Basidiomyceten (Dr. L. Rabenhorst's Kryptogamen-Flora von Deutschland, Oesterreich und der Schweiz, 2nd edn, 1.1 Pilze). Kummer, Leipzig

Wiseman MS, Dugan FM, Kim YK, Xiao CL (2015) A Postharvest Fruit Rot of Apple Caused by Lambertella corni-maris in Washington State. Plant Dis. 99(2), 201-206

Zogg H (1985) Die Brandpilze Mitteleuropas unter besonderer Berücksichtigung der Schweiz. Cryptogam Helv 16:5-277

Zundel GL (1953) The Ustilaginales of the world. Contr Dept Bot Pennsylvania State College 176: 1-410

\section{Figures}




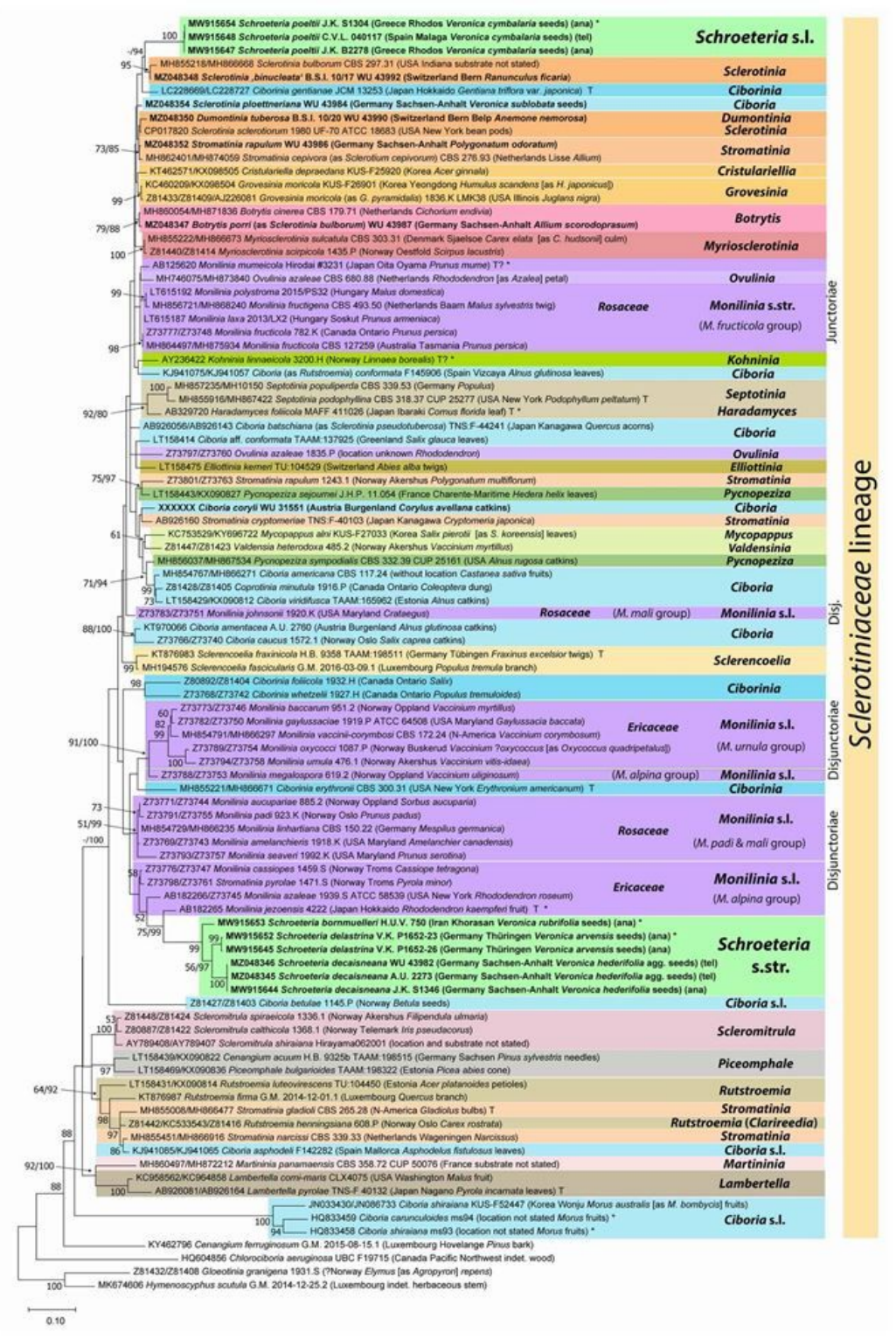

\section{Figure 1}

Combined maximum likelihood analysis of the Sclerotiniaceae lineage (including Rutstroemiaceae and Piceomphale clade), based on ITS1-5.8S-ITS2 and LSU D1-D2 rDNA, obtained with MEGAX (model GTR+G+l, 500 replicates). The outgroup comprises members of Cenangiaceae, Chlorociboriaceae, and Helotiaceae. Bootstrap values below 50 are not shown, those after the slash were obtained with IQtree (see S3) and are given whenever they distinctly deviated from those obtained with MEGAX. The asterisk indicates that only ITS was available. The different genera are highlighted in different colours. 

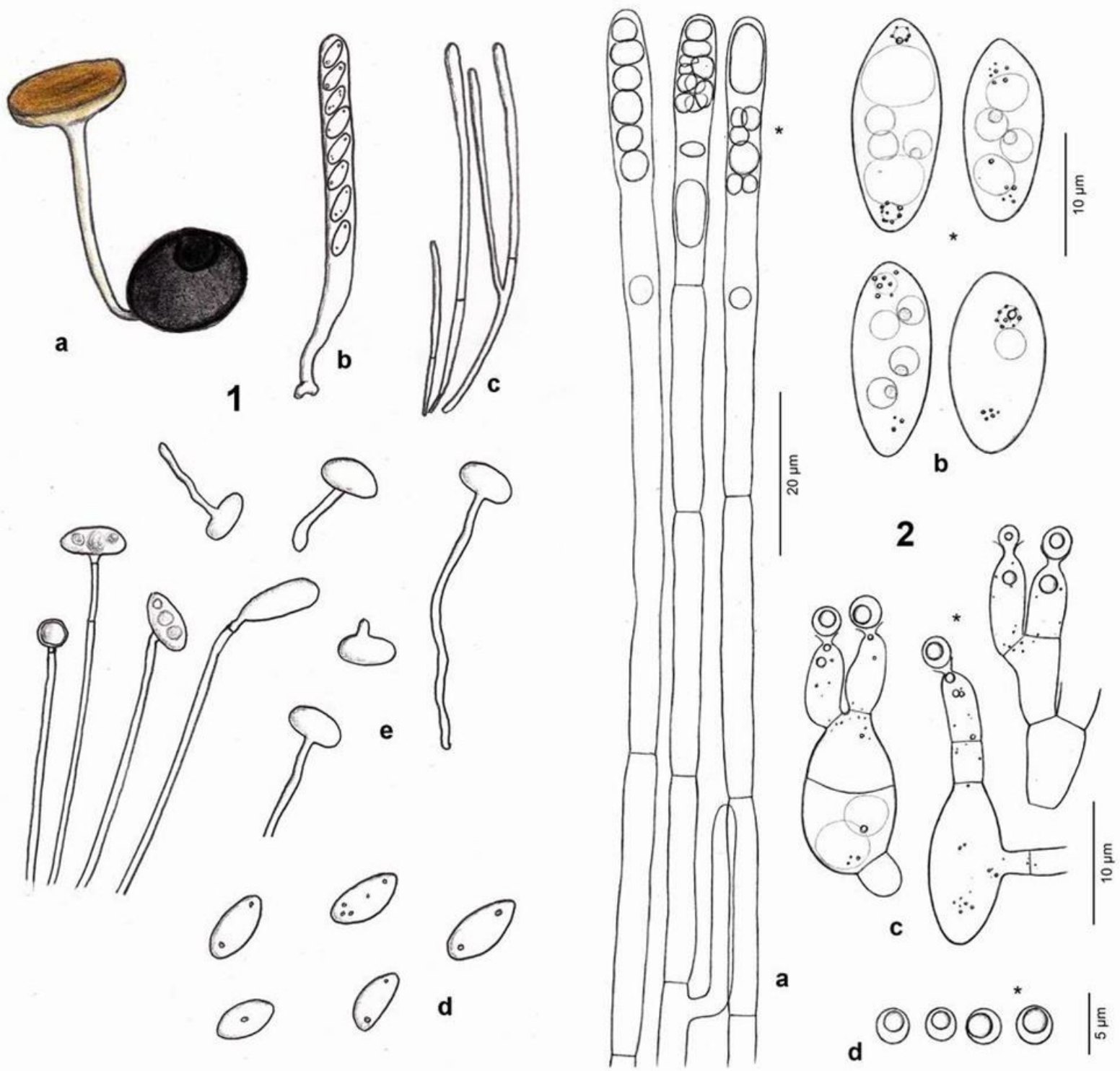

Figure 2

Ciboria ploettneriana (from Sachsen-Anhalt, Freyburg). 1a. fresh apothecium emerging from blackened seed. 1b. ascus; 1c, 2a. paraphyses, terminal cell containing hyaline VBs; $1 \mathrm{~d}, 2 \mathrm{~b}$. mature ascospores containing some minute LBs near each end (in 2b. 2-4 central nuclei and two vacuoles visible); 1e. overmature ascospores with germ tubes (in hymenium); 2c. overmature ascospores budding conidia (in hymenium); $2 \mathrm{~d}$. conidia detached from ascospores, containing one large eccentrical LB. All in water, all in living state except for ascus in 1b and paraphyses in 1c. - 1. 12.IV.2004: Hirschrodaer Graben; 2. 13.IV.2009 (H.B. 9037): Zeuchfeld. - Del. 1. P. Rönsch (not drawn to scale); 2. H.O. Baral. 


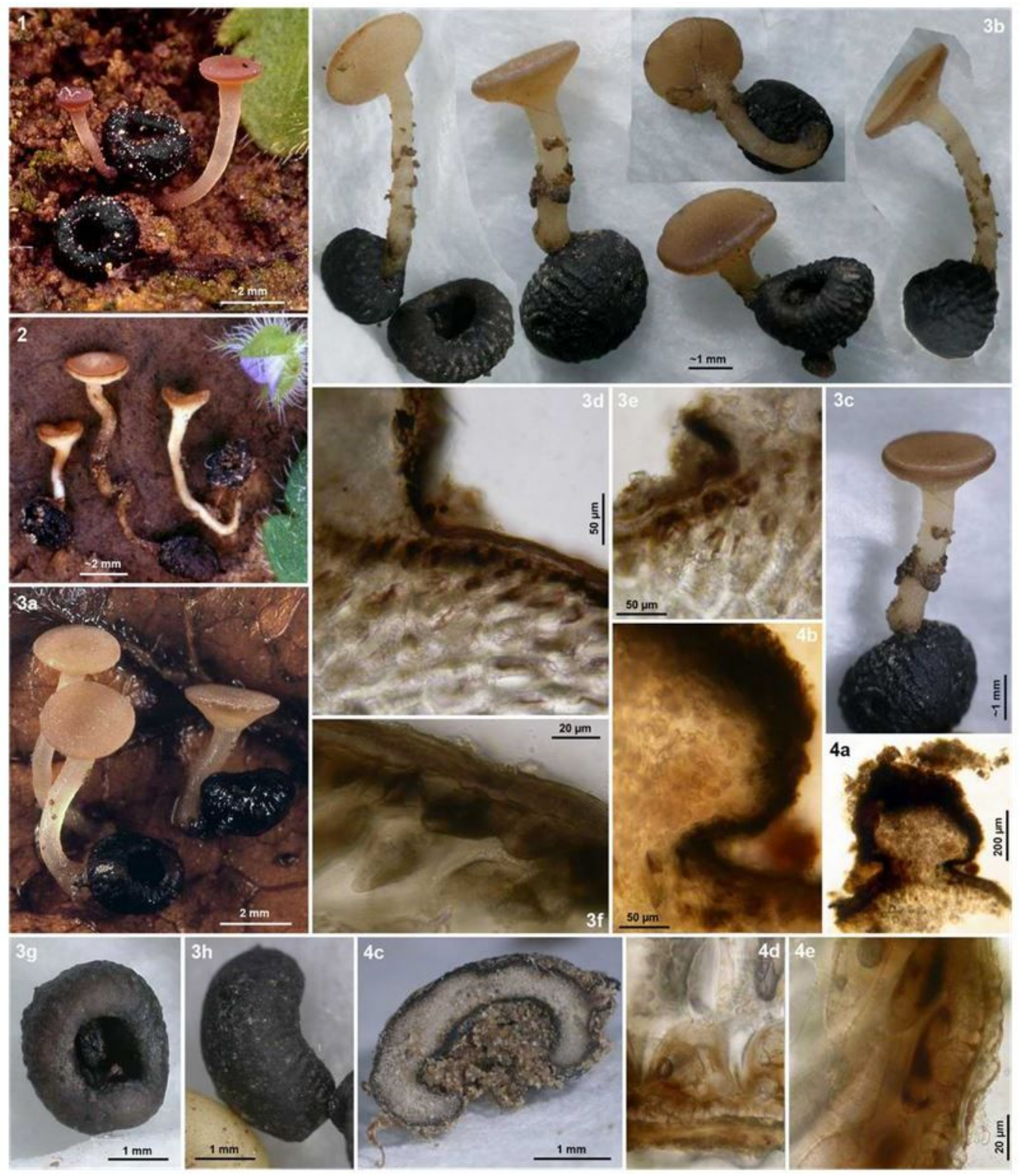

Figure 3

Ciboria ploettneriana (from Sachsen-Anhalt, Freyburg). 1, 2, 3a-c. fresh apothecia emerging from stromatized (blackened) seeds of Veronica hederifolia agg.; $3 \mathrm{~g}-\mathrm{h}$. infected (blackened) seeds (3h. with uninfected whitish seed below); 4c. median section of infected seed; $3 f, 4 d-e$. idem, detail of stromatized cortex of seed; $3 d-e$. median section of apothecial stipe base and seed tissue; $4 a-b$. idem, young apothecium, medullary excipulum containing crystal druses. All in fresh state. - 1. 15.IV.2004: Alte Göhle; 2. 12.IV.2004: Hirschrodaer Graben (from HUTH 2009: pl. 36 fig. 104); 3. 13.IV.2009 (H.B. 9037): Zeuchfeld; 4. $23 . I V .2010$ (H.B. 9271): Alte Göhle. - Phot. 1, 2, 3a. P. Rönsch; 3b-h, 4a-e. H.O. Baral. 


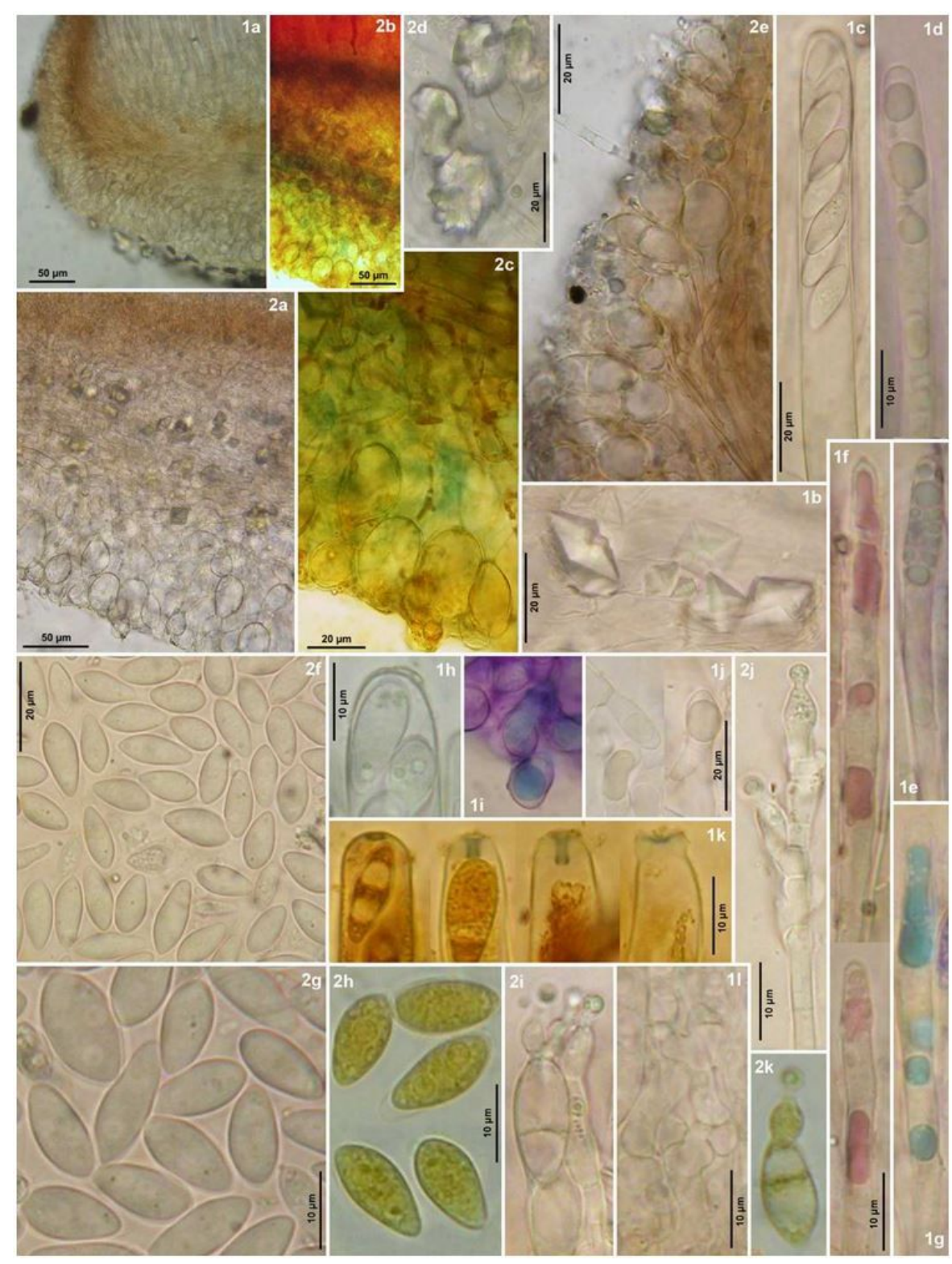

\section{Figure 4}

Ciboria ploettneriana (from Sachsen-Anhalt, Freyburg). 1a. median section of receptacle; 2a-c. idem, ectal excipulum at flanks; 2e. idem, at margin; $2 \mathrm{~d}, 1 \mathrm{~b}$. idem, medullary excipulum with crystals; $1 \mathrm{i}-\mathrm{j}$. hair-like elements on ectal excipulum at flanks, containing refractive vacuoles (staining turquoise in CRB); $1 \mathrm{c}$. ascus; $1 \mathrm{l}$. ascogenous hyphae with croziers; $1 \mathrm{~h}, \mathrm{k}$. apices of immature and mature asci; $1 \mathrm{~d}-\mathrm{f}$. paraphyses, containing refractive vacuoles (in $1 \mathrm{f}$. turning purplish with age), $1 \mathrm{~g}$. stained turquoise in $\mathrm{CRB} ; 2 \mathrm{f}-\mathrm{g}$. mature ascospores containing a few minute LBs, 2-4 nuclei faintly visible; $2 \mathrm{~h}$. idem, in IKI, nuclei distinctly visible; 2i, $\mathrm{k}$. overmature ascospores budding conidia from phialides; $2 \mathrm{j}$. phialides formed on germ tube. Living state (in water; $2 \mathrm{~b}-\mathrm{c}, 2 \mathrm{~h}, 2 \mathrm{k}$. in IKl; $1 \mathrm{f}$. in water, colour change in older apothecia; 1g, 1i. in CRB), dead state (1k. in IKI). - 1. H.B. 9271: Alte Göhle; 2. H.B. 9037: Zeuchfeld. - Phot. H.O. Baral. 

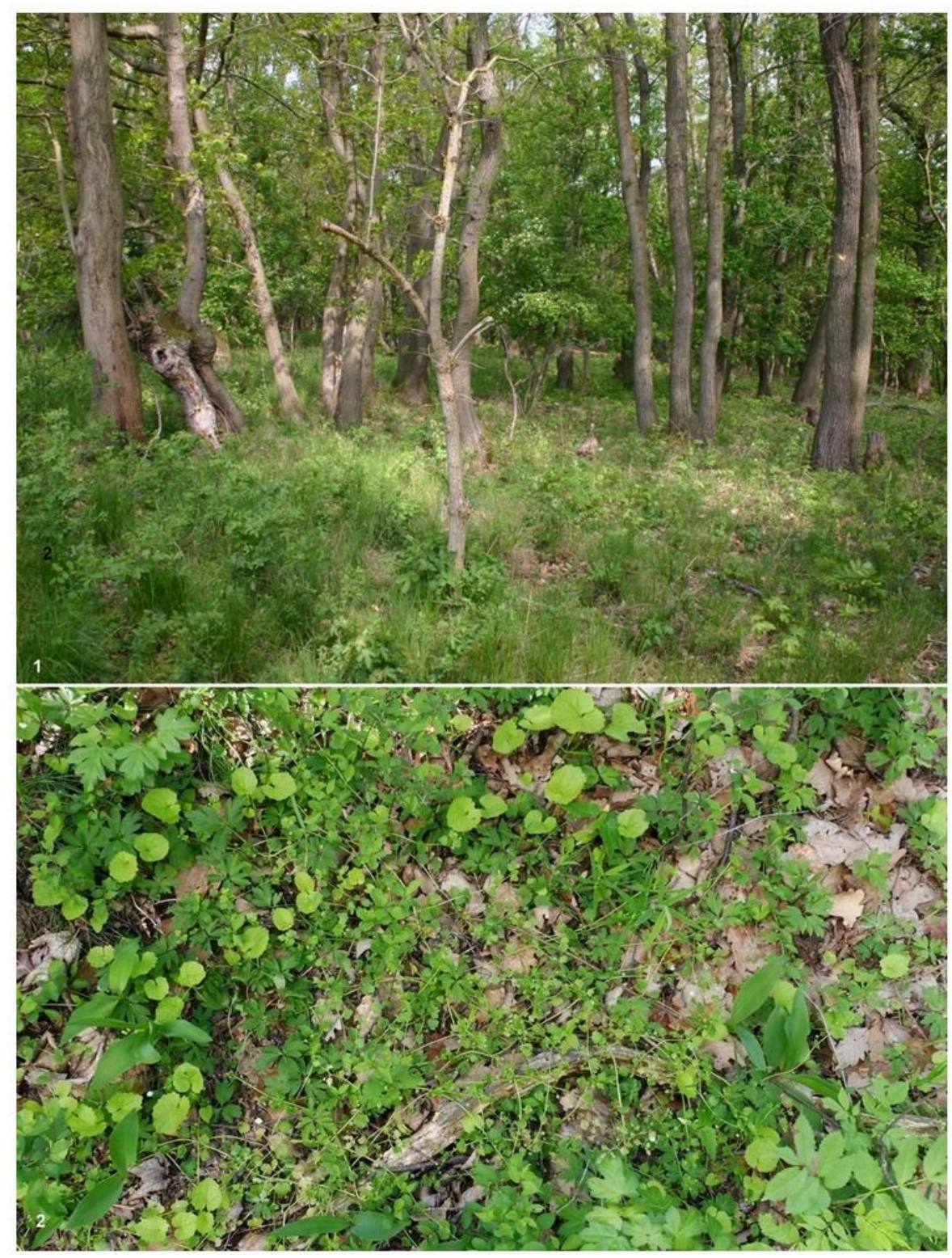

\section{Figure 5}

Ciboria ploettneriana biotop (Germany, Sachsen-Anhalt, Naumburg, Roßbach, Scherbitzberg-Schlucht): 1. mixed oak forest (Alliarion) on calcareous soil (Muschelkalk covered by Loess), with Quercus robur, Acer campestre, Crataegus monogyna, Fraxinus excelsior; Veronica? sublobata occurring close to the forest edge on the left; 2. view on Veronica hederifolia agg. population (apparently V. sublobata) with Alliaria petiolata, Anemone nemorosa, Convallaria majalis, Dactylis sp. (not on photo), Polygonatum multiflorum (not on photo), Stellaria holostea, young Acer campestre and Fraxinus excelsior. - Phot. W. Huth (2.V.2019). 


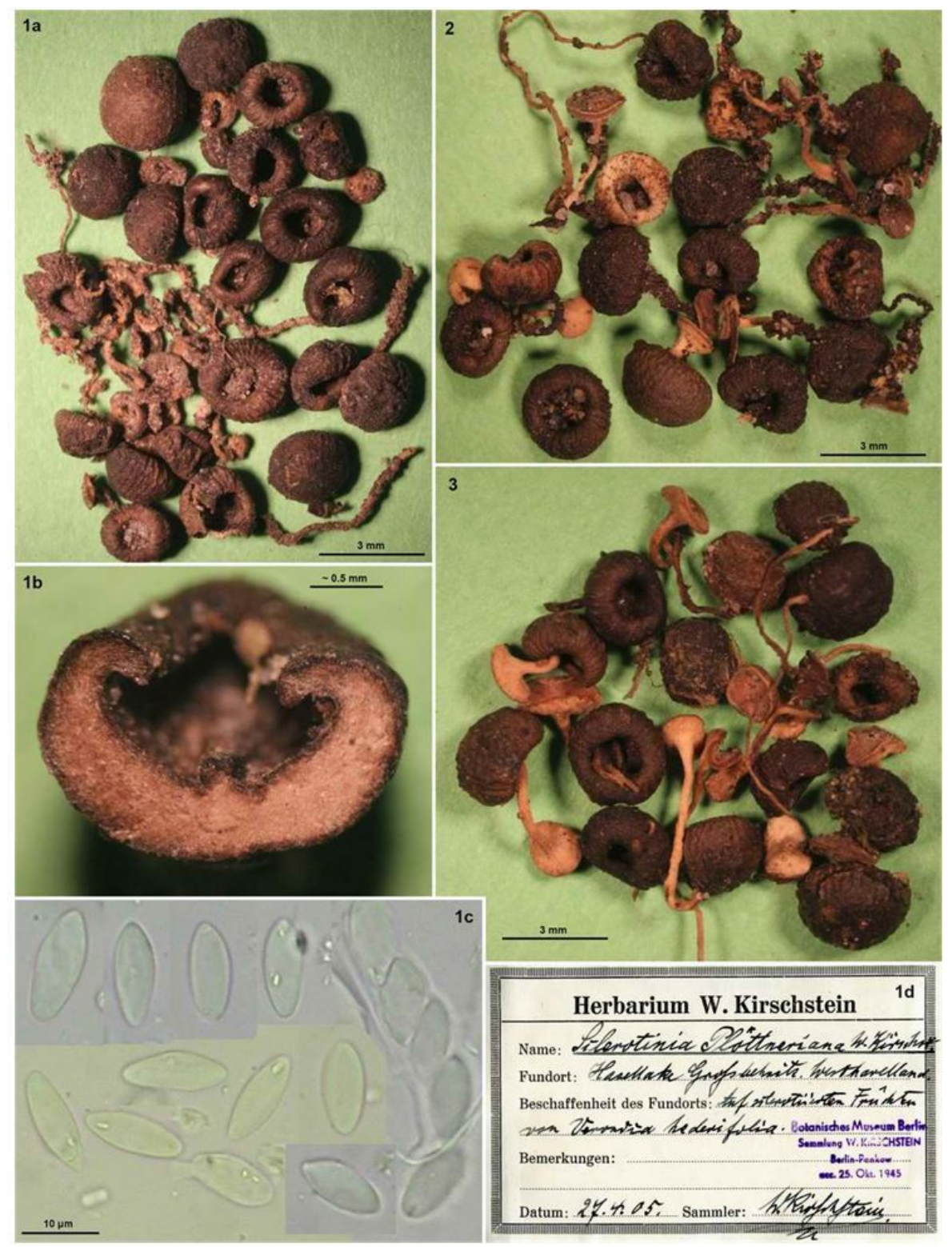

Figure 6

Ciboria ploettneriana (from Kirschstein's and Benkert's collections). 1a, 2-3. dry apothecia on blackened seeds of Veronica hederifolia agg.; 1b. median section of seed; 1c. ascospores (in KOH); 1d. original label of lectotype written by Kirschstein. - 1a-d. $27 . I V .1905$ (B 70 0100006, lectotype): Brandenburg-Groß Behnitz; 2. $30 . I V .1992$ (B 70 0009941): Berlin-Treptow; 3. 27.IV.1972 (B 70 0009940): TeupitzEgsdorf. - Phot. V. Kummer. 

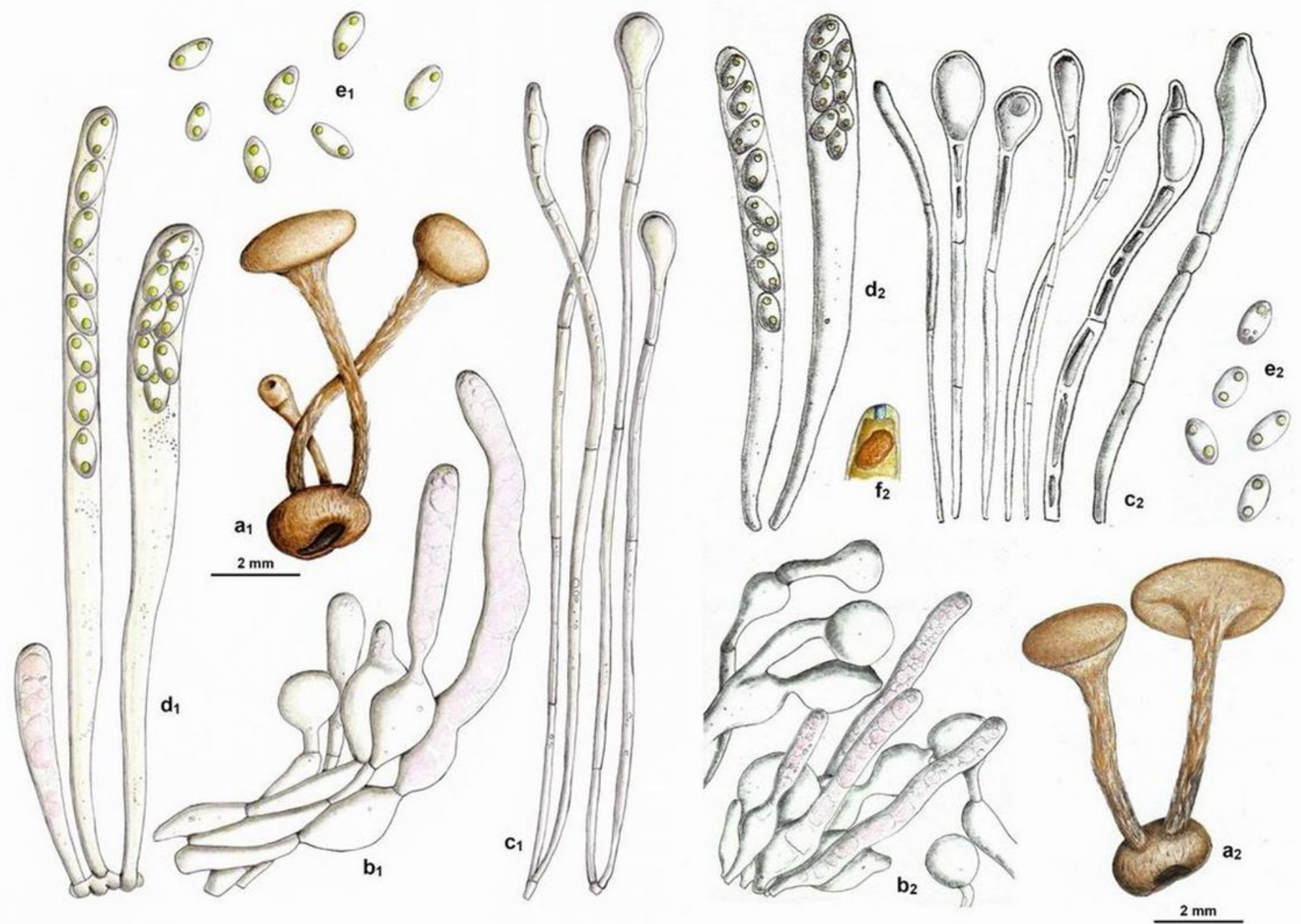

Figure 7

Schroeteria decaisneana (teleomorph, H.B. 8687: Sachsen-Anhalt, Freyburg, Zeuchfeld). a. fresh apothecia emerging from seeds of Veronica hederifolia agg.; b. marginal excipular cells; c. paraphyses; d. asci; e. ascospores; f. ascus apex in IKI. Living state, except for some cells of the paraphyses. - Del. P. Rönsch (microscopic elements not drawn to scale, numbers 1 and 2 refer to different apothecia). 


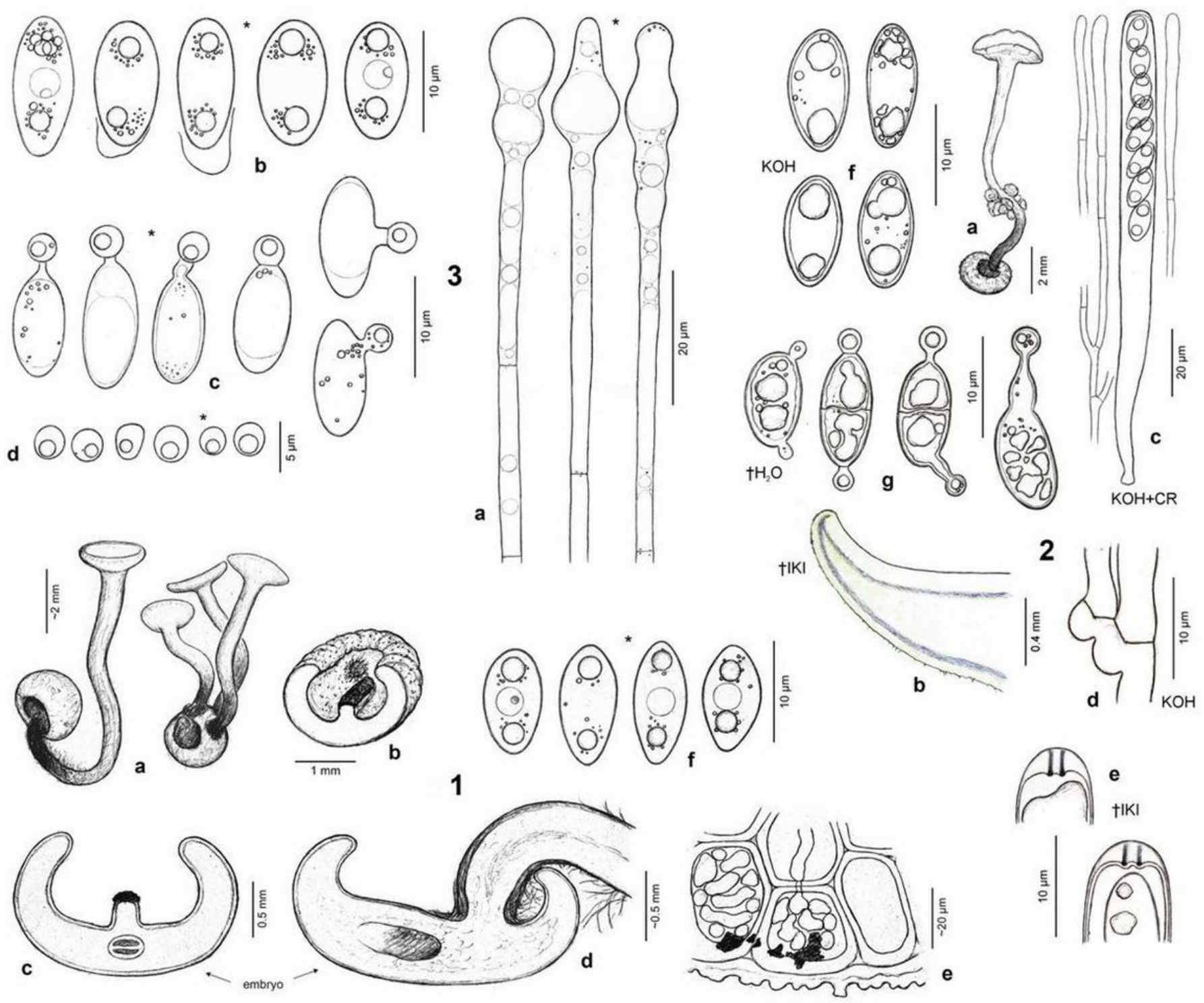

Figure 8

Schroeteria decaisneana (teleomorph). 1a. fresh apothecia emerging from seeds of Veronica hederifolia agg.; 2a. idem, rehydrated; $1 b-d$. median section of seed ( $b-c$. with central hilum, $c-d$. with embryo, $d$. with insertion of apothecial stipe); $1 \mathrm{e}$. hyphae inside epidermial cells of seed; 2b. median section of receptacle (with amyloid subhymenium and outer medullary excipulum); $2 \mathrm{c}$. ascus and paraphyses; $2 \mathrm{~d}$. ascus bases with croziers; 2e. apices of immature (above) and mature (below) asci; 3a. paraphyses, terminal cell containing inconspicuous large vacuoles but no VBs; $1 \mathrm{f}, 2 \mathrm{f}, 3 \mathrm{~b}$. mature ascospores containing one central nucleus and one large and some minute LBs at each end); $2 \mathrm{~g}$, 3c. overmature ascospores budding conidia; $3 \mathrm{~d}$. conidia detached from ascospores, containing one large eccentrical LB. Living state (1 \& 3.), dead state (2.). - 1. H.B. 2981: Schaffhausen, Thayngen, Flüheweg; 2. H.B. 5698: Unterfranken, Schweinfurt, Alter Main; 3. H.B. 8687: Sachsen-Anhalt, Freyburg, Zeuchfeld. - Del. H.O. Baral. 


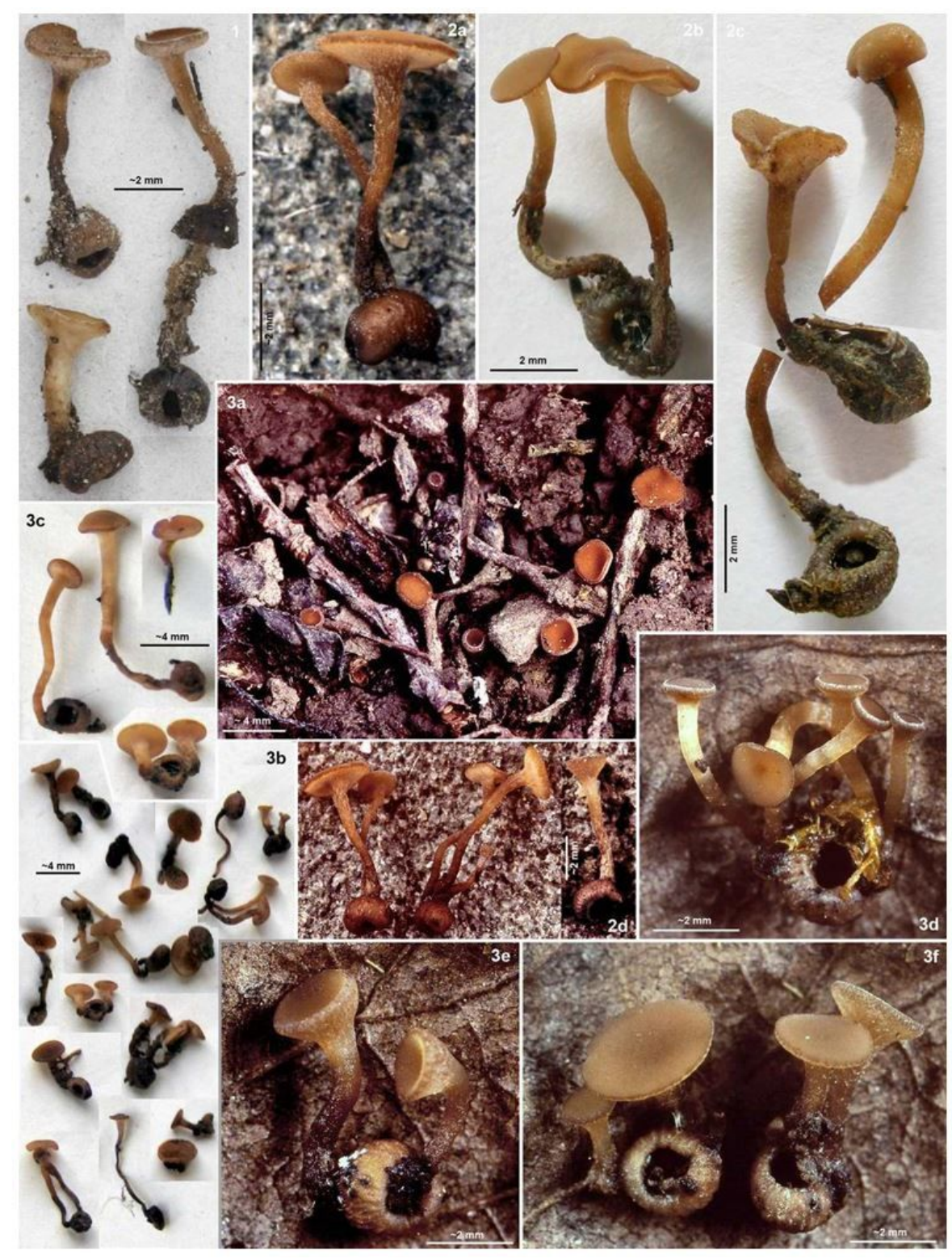

Figure 9

Schroeteria decaisneana (teleomorph, from Sachsen-Anhalt). 1, 2a-d, 3b-f. apothecia emerging from stromatized (partially blackened) seeds of Veronica hederifolia agg.; 3a. apothecia in situ (seeds hidden in soil under organic debris). All in fresh state. - 1. G.H. 080309: Merseburg, Burgliebenau; 2. H.B. 8687: Freyburg, Zeuchfeld; 3. H.B. 8955: ibid. - Phot. 1. G.. Hensel; 2a, 3a-f. P. Rönsch; 2b-c. H.O. Baral. 

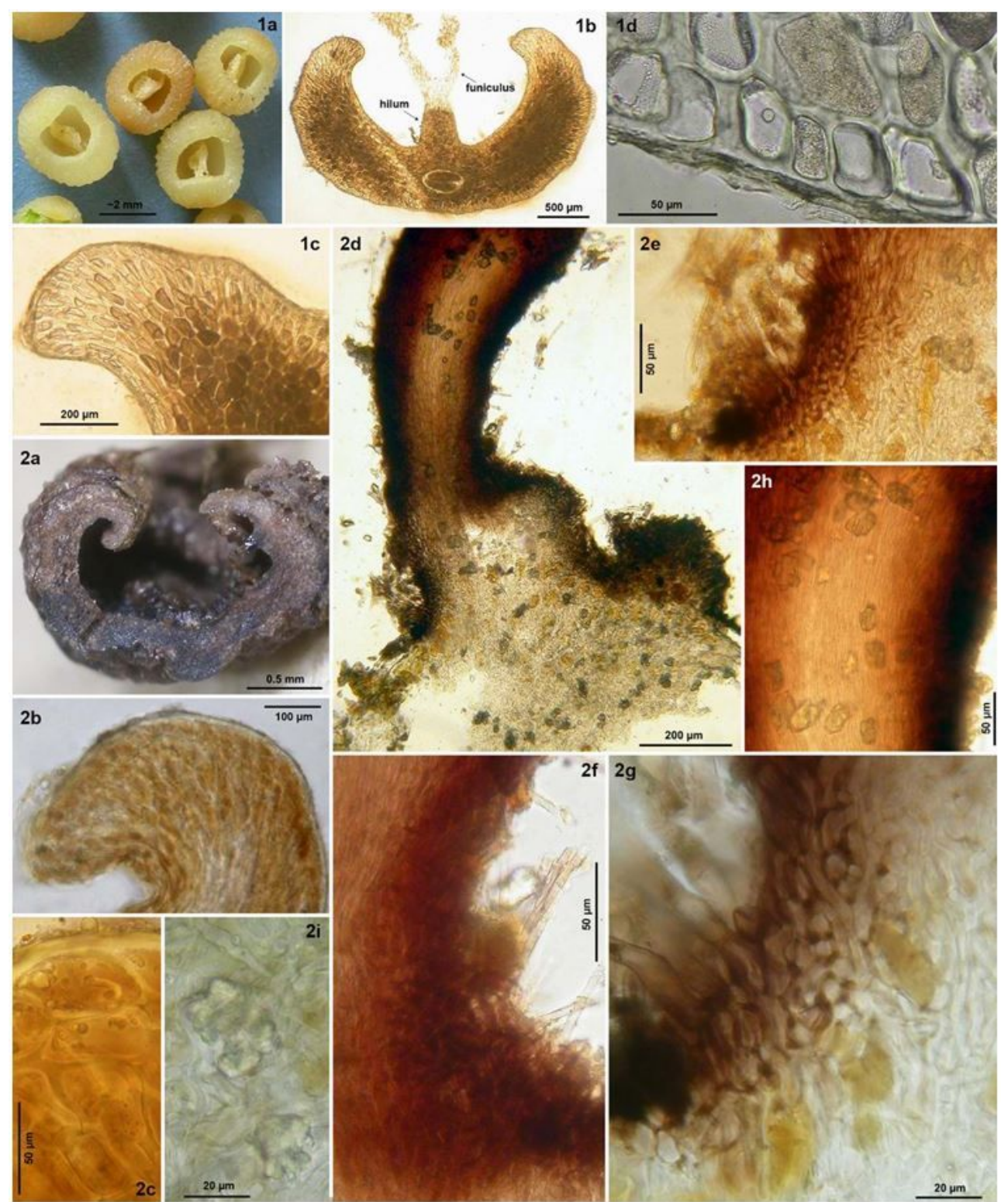

\section{Figure 10}

Uninfected seeds of Veronica hederifolia agg. (1.), Schroeteria decaisneana stromatized seed and base of apothecial stipe (2.). 1 a. uninfected seeds with deep cavity and central attachment (hilum and funiculus); $1 \mathrm{~b}, 2 \mathrm{2}$. median section of seed (1b. showing embryo below hilum); $1 \mathrm{c}, 2 \mathrm{~b}-\mathrm{c}$. idem, detail of marginal part of seed; $1 \mathrm{~d}$. idem, lower part of seed; $2 \mathrm{~d}$. median section of stromatized apothecial stipe and basal stroma; $2 \mathrm{e}-\mathrm{g}$. idem, details of stroma and stipe base (with hairs); $2 \mathrm{~h}$. idem, crystals in medullary excipulum of stipe; $2 \mathrm{i}$. idem, crystals in medullary excipulum of basal stroma. - Mounted in water (fresh state); - 1a-d. 13.V.2008: Tübingen-Pfrondorf, Blaihofstr. 42; 2. H.B. 8687: Sachsen-Anhalt, Freyburg, Zeuchfeld. - Phot. H.O. Baral. 


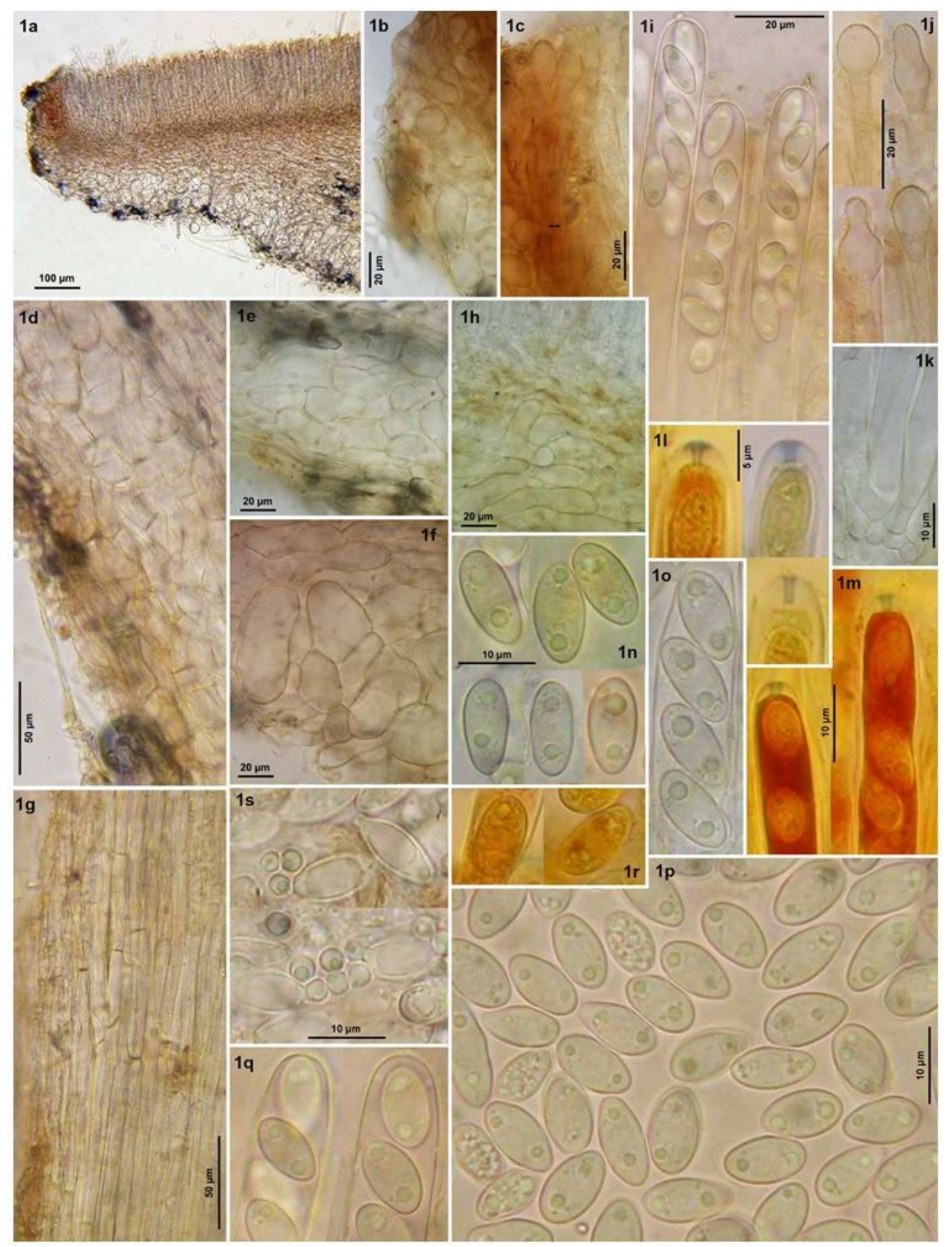

Figure 11

Schroeteria decaisneana (teleomorph, H.B. 8687, Sachsen-Anhalt, Freyburg, Zeuchfeld). 1a. median section of receptacle; 1b-c. idem, ectal excipulum at margin (1c with paraphysis-like intermediate elements); $1 \mathrm{~d}-\mathrm{f}$. idem, ectal excipulum at lower flanks and junction with stipe; $1 \mathrm{~g}$. idem, ectal excipulum in stipe; $1 \mathrm{~h}$. idem, medullary excipulum and subhymenium; $1 \mathrm{i}$. mature asci; $1 \mathrm{j}$. paraphyses, containing large non-refractive vacuoles; $1 \mathrm{k}$. ascus bases with croziers; $1 \mathrm{l}-\mathrm{m}, \mathrm{o}, \mathrm{q}$. apices of mature asci (I-m. with amyloid ring); $1 \mathrm{n}, \mathrm{p}$. free ascospores containing two large and some minute LBs, central nucleus faintly visible; $1 \mathrm{r}$. central nucleus more clearly visible (right spore with two glycogen regions); $1 \mathrm{~s}$. overmature ascospores budding conidia with large eccentrical LB. Living state (in water, 1r. in IKI), except for $1 \mathrm{I}-\mathrm{m}$. (dead state in IKI), ascus in 10., four spores in 1p. - Phot. H.O. Baral. 

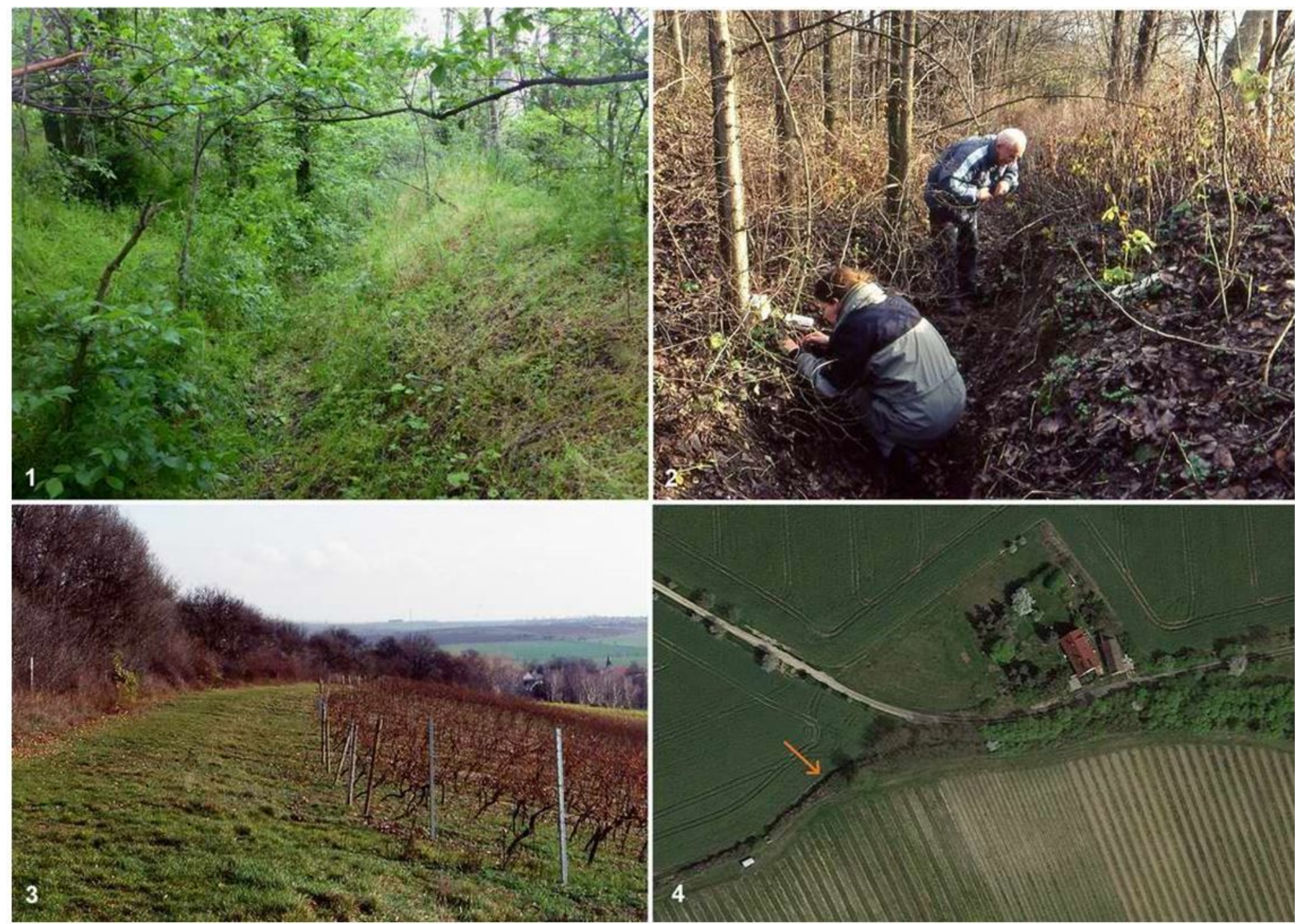

\section{Figure 12}

Collection site of Schroeteria decaisneana (teleomorph, from Sachsen-Anhalt, Freyburg, Zeuchfeld). 1-2. dry draining ditch in temperate humid, thermophilous forest strip between cornfield in the north and vineyard in the south, in spring (1., 21.V.2019) and late autumn (2., 16.XI.2008, H.B. 8955), with Ulmus minor, Acer campestre, Veronica hederifolia agg., S. Thieme \& U. Richter; 3 . vineyard south of forest strip (16.XI.2008); 4. location of forest strip in the west of Zeuchfeld (Google Earth). - Phot. 1. U. Richter, 2-3. P. Rönsch, 4. from Google Earth. 

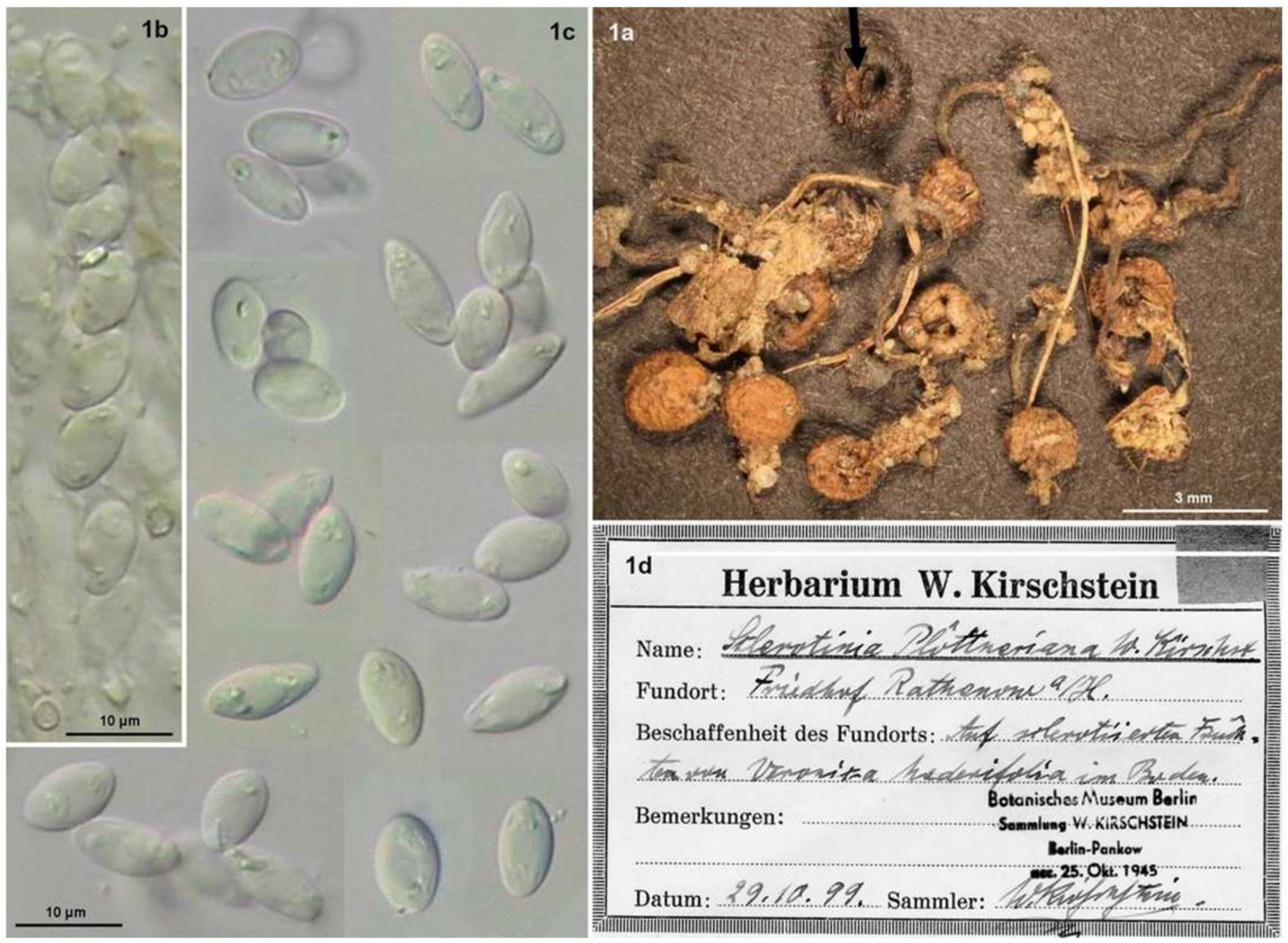

\section{Figure 13}

Schroeteria decaisneana (from Kirschstein's collection 29.X.1899 under the name Sclerotinia ploettneriana, B 70 0100003, Brandenburg, Rathenow). 1a. dry apothecia on light brown seeds of Veronica hederifolia agg. (the arrow points to one blackened seed which appears to belong to Ciboria ploettneriana); 1b. ascospores in ascus (in $\mathrm{KOH}$ ); 1c. free ascospores (in $\mathrm{KOH}$ ); 1d. original label written by Kirschstein. - Phot. V. Kummer. 


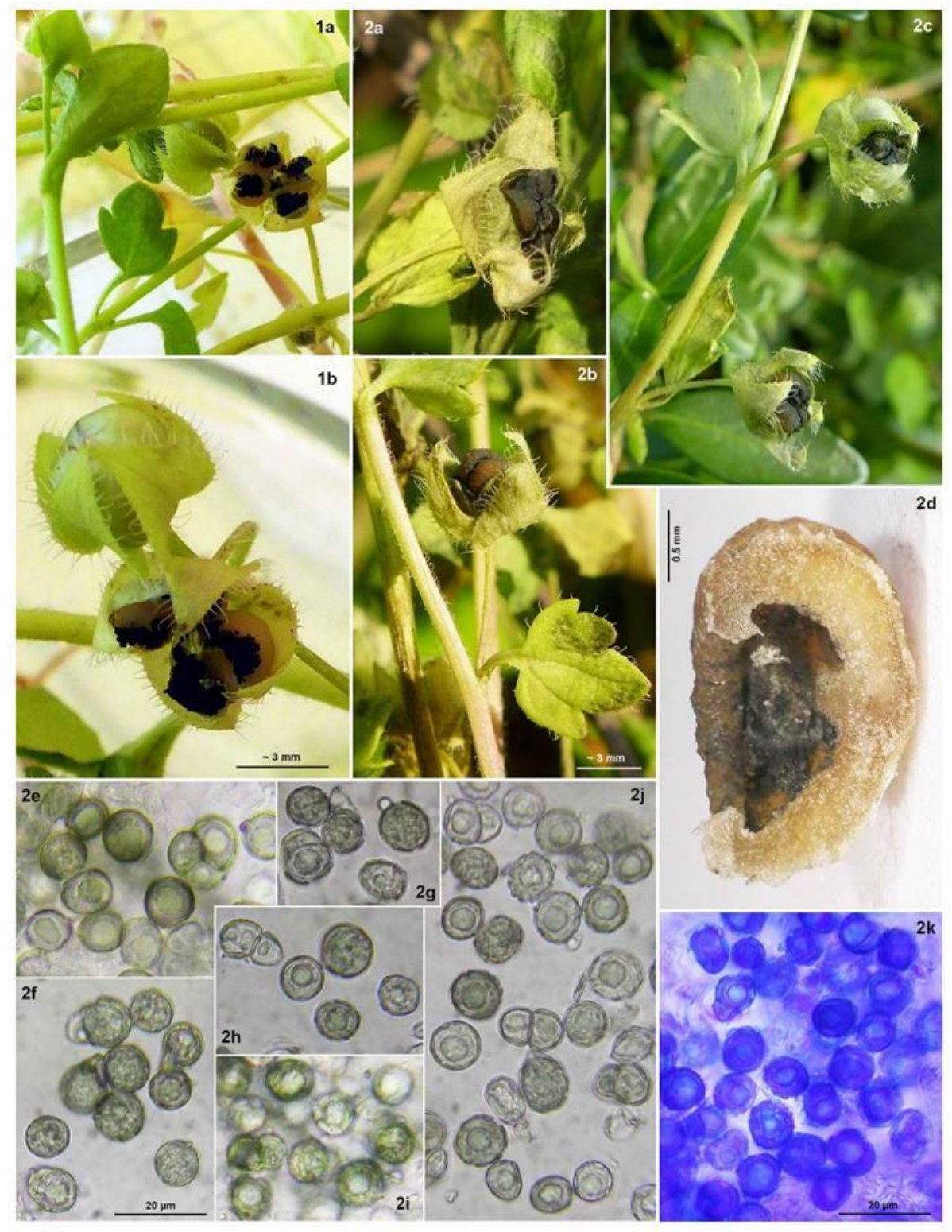

Figure 14

Schroeteria decaisneana (anamorph, from Sachsen-Anhalt, Freyburg, Zeuchfeld, on Veronica hederifolia s.str.). 1a-e. infected plant with black sori in the cavity of each seed; $2 a$. median section of infected seed, with chlamydospores formed on hilum/funiculus; $2 b-h$. chlamydospores (singly, rarely in pairs). - 1a-b. 13.V.2019 (V.K. P1656-10); 2a-k. 21.V.2019 (J.K. S1346, GLM-F129032,H.B. 10206). Phot. 1a-b. U. Richter (fresh), 2a-c. J. Kruse (half dried); 2d-k. H.O. Baral (dead state, e-j. in water, k in CRB). 


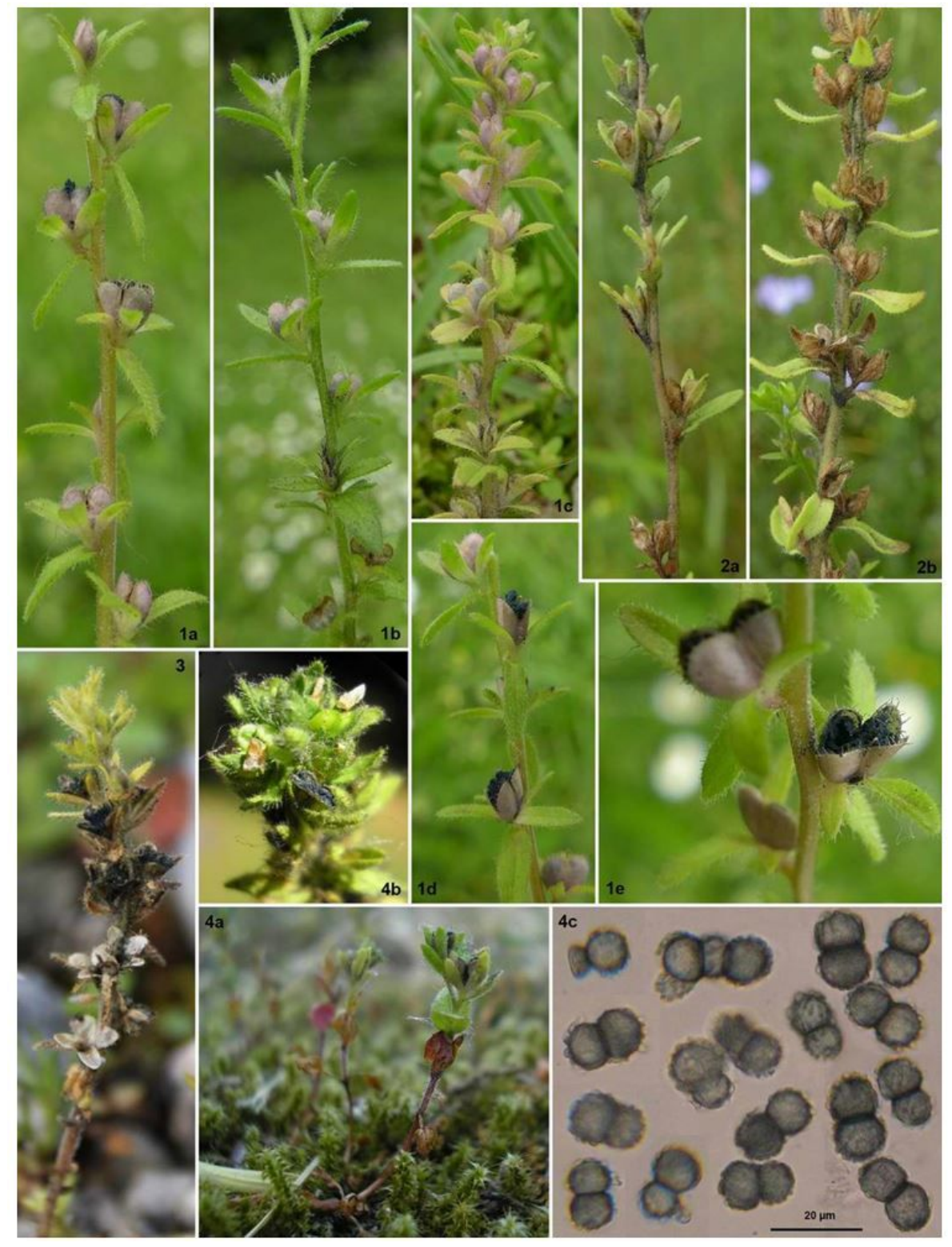

\section{Figure 15}

Schroeteria delastrina (anamorph) on Veronica arvensis. 1a-e. 9.VI.2017: Sachsen-Anhalt, Rosstrappe; 2a-b. 11.VI.2016: Hessen, Darmstadt; 3. V.K. P1652-20: Rhodos, Kamiri monastery; 4a-c. 30.V.2011: Niedersachsen, Hannover. - Phot. 1-2, 4. J. Kruse, 3. V. Kummer. 


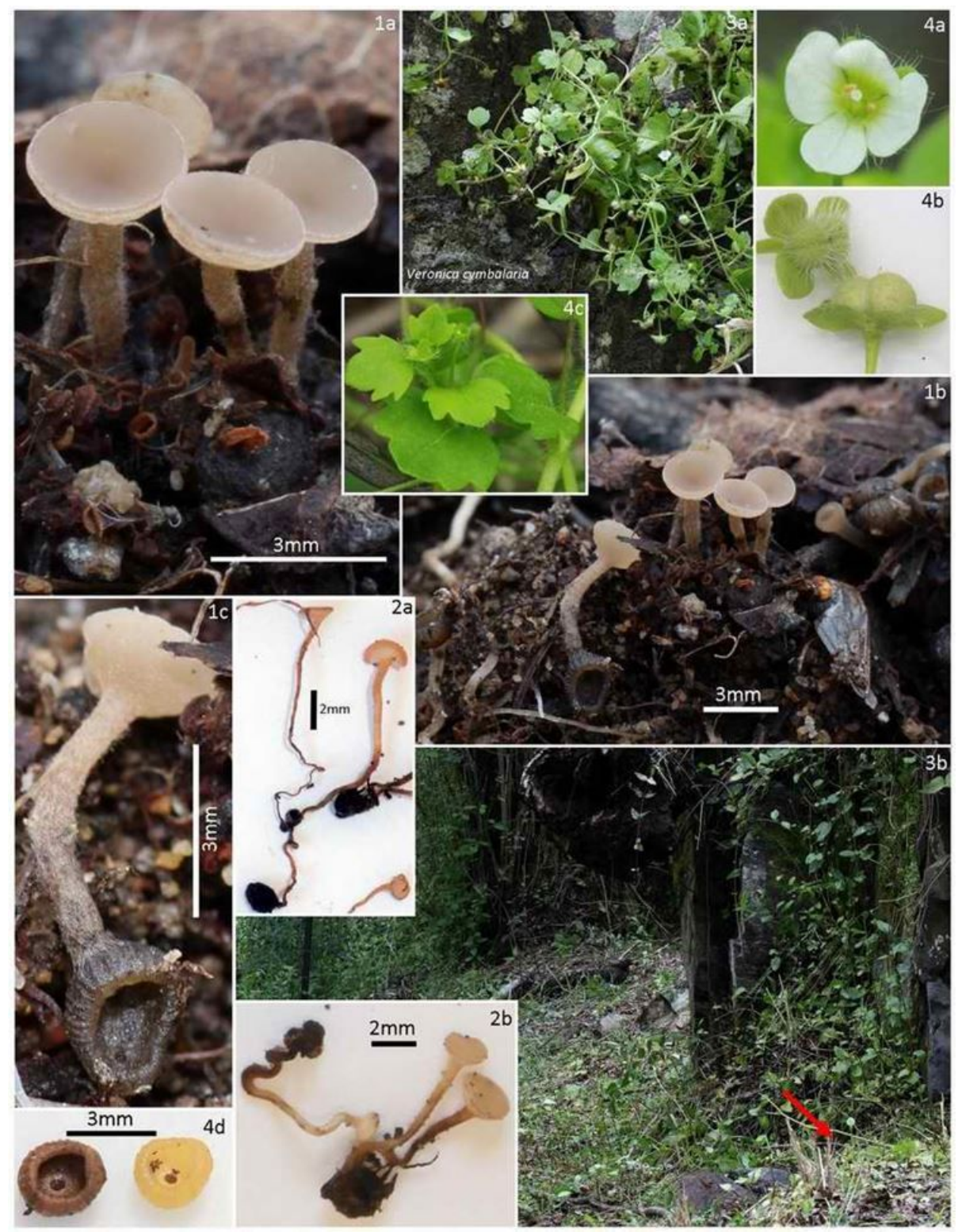

Figure 16

Schroeteria poeltii (teleomorph). 1a-c, 2a-b. apothecia emerging from stromatized seeds of Veronica cymbalaria (1 in situ); $3 a-b$. collection site with V. cymbalaria growing on vertical schist rock, apothecia found on seeds fallen to the ground; $4 a-c$. uninfected flower, fruits and leaves of V. cymbalaria; 4d. infected and uninfected mature seed. Fresh state. - 1a-c, 2a-b, 4d. 4.I.2017 (C.V.L. 040117). Spain, Andalucía, Málaga, Pujerra; 3a-b, 4a-c. 28.V.2020. ibid. - Phot. F.J. Valencia. 


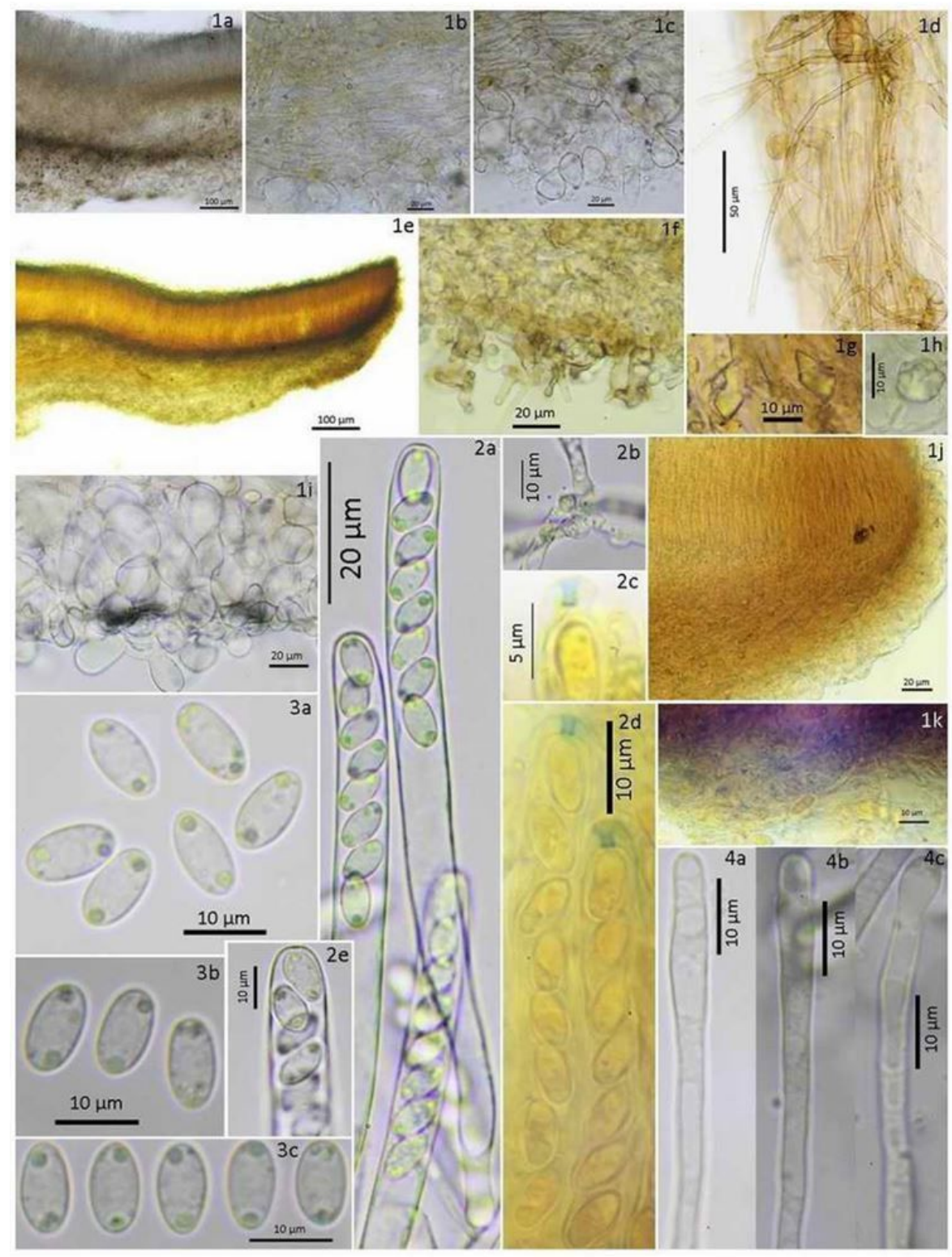

Figure 17

Schroeteria poeltii (teleomorph). 1a, e, j. Median section of apothecium (1e in IKI, 1f, j in KOH); 1b. idem, medullary excipulum; $1 \mathrm{c}$, $\mathrm{f}$, i. idem, ectal excipulum; $1 \mathrm{~d}$. Surface view on stipe showing hairs (in $\mathrm{KOH}$ ); $1 \mathrm{~g}-\mathrm{h}$. crystals in stipe and medullary excipulum, respectively (in $\mathrm{KOH}$ ); $1 \mathrm{k}$. faintly amyloid subhymenium (in IKI); 2a, e. living mature asci; 2b. ascus base with croziers; 2c-d. dead asci and spores (in IKI), with amyloid ring; 3a-c. living ascospores; 4a-c. living paraphyses. In water, if not otherwise stated. - 1-4. 4.I.2017 (C.V.L. 040117). Spain, Andalucía, Málaga, Pujerra. - Phot. F.J. Valencia. 


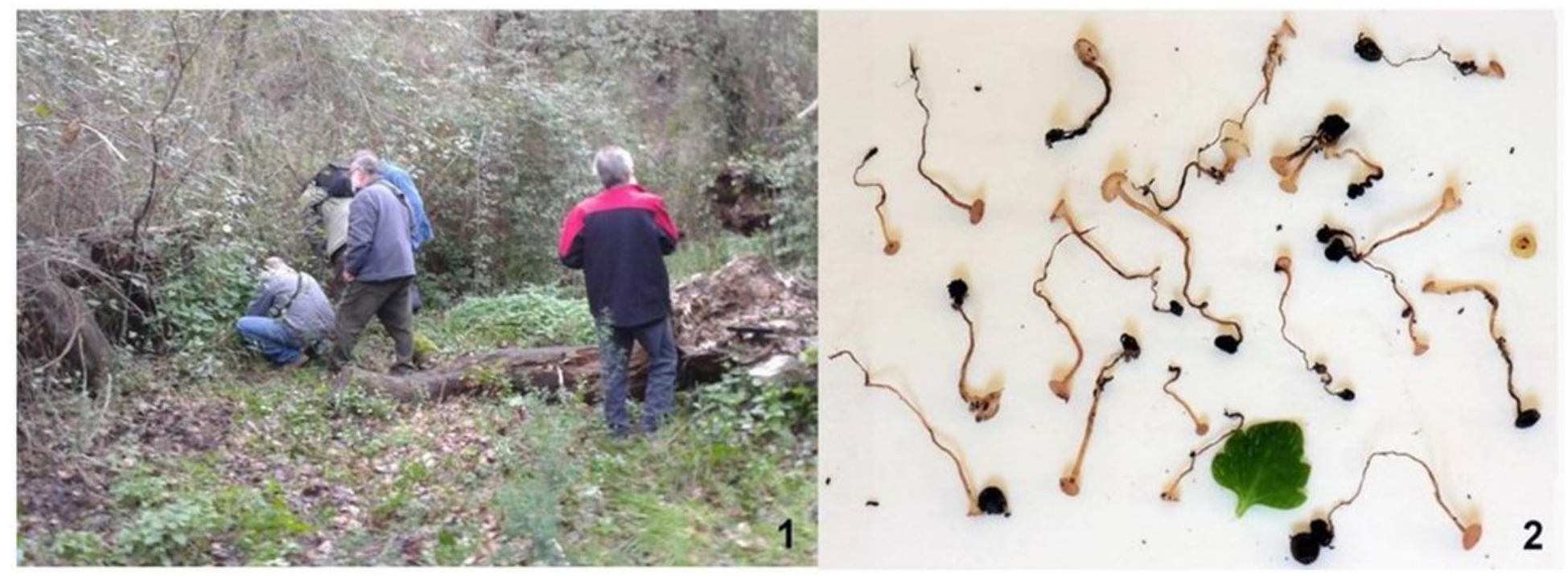

\section{Figure 18}

Schroeteria poeltii (teleomorph, C.V.L. 040117: Spain, Andalucía, Málaga, Pujerra). 1. supramediterranean floodplain forest with Populus alba, Salix alba, Quercus faginea, Veronica cymbalaria and various other mediterranean herbs; 2 . apothecia on stromatized seeds of Veronica cymbalaria. - Phot. 1. C. Borrego, 2. F.J. Valencia. 


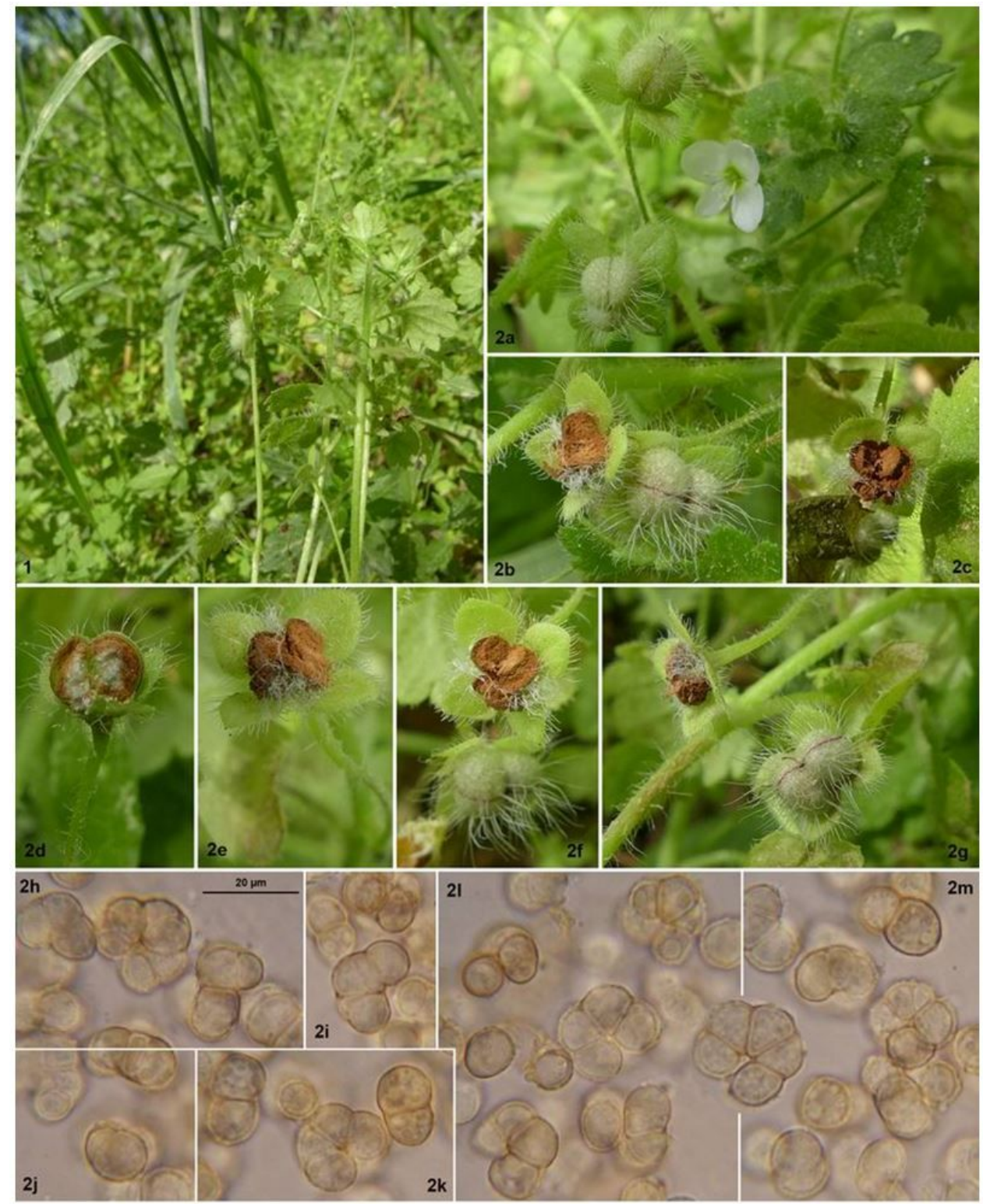

Figure 19

Schroeteria poeltii (anamorph, on Veronica cymbalaria). 1. ruderal meadow; 2a. uninfected plant; 2b-g. opened capsules exposing brown sori; $2 \mathrm{~h}-\mathrm{m}$. chlamydospores (living state, in water) cohering in numbers of 2-5. - 1. 21.III.2018. Greece, Rhodos, Archangelos, Charaki; 2. 20.III.2018. ibid., lalysos, Filerimos. - Phot. J. Kruse. 


\section{Gemimella Siebroeter nov. gen. \\ (Thecaphora Fingh. pr. p.)}

Sporis geminis vel rarius seriatim ternis consociatis, frictione in singulas distrahendis; geminatim consociatis, forma ellipsoidea, medio constricta el septata.

G. Delastrina (Tulasne) Schroet. - (Thecaph. Delastr., Tul. Annal. d. Sc. natur. III me. Série Botan. Tom. 7. pag. 108. Tab. 4. f. 24-25.)

Sporis geminis, rarius ternis cinereis singulis rotundis; episporio hyalino superficie rugulosa; endosporio guttis singulis oleosis. Sporae singulae 2, 5-3 Microm., consociatae geminae $5,5-6$ Microm. (1 Divis. $=0,002 \mathrm{~mm}$.)

In den Samenkapseln von Veronica arvensis. Bei Liegnitz in Schlesien, Mai $1869 . \quad$ Dr. Schneider.

NB. Da nach Tulasne bei seiner Gattung: T hec aphora die Zwillings - oder gedreiten Sporoiden jede von einer besondern Membran eingeschlossen sein sollen, bei der vorliegenden aber die Sporoiden, wie man sich durch das Mikroskop überzeugen kann, von einer gemeinsamen Membran umschlossen sind, so dürfte diese Differenz die Aufstellung einer neuen Gattung rechtfertigen. Möglicherweise liegt bei Tulasne ein Fehler in der mikroskopischen Beobachtung zu Grunde.

Figure 20

SCHRÖTER's (1870) description of the genus Schroeteria under the illegitimate name Geminella on the herbarium label of an exsiccata of the type species G. delastrina from Silesia in Rabenhorst's Fungi Europaei exsiccati Cent. 14: no. 1376 (U. BRAUN \& K. BENSCH pers. comm.). 

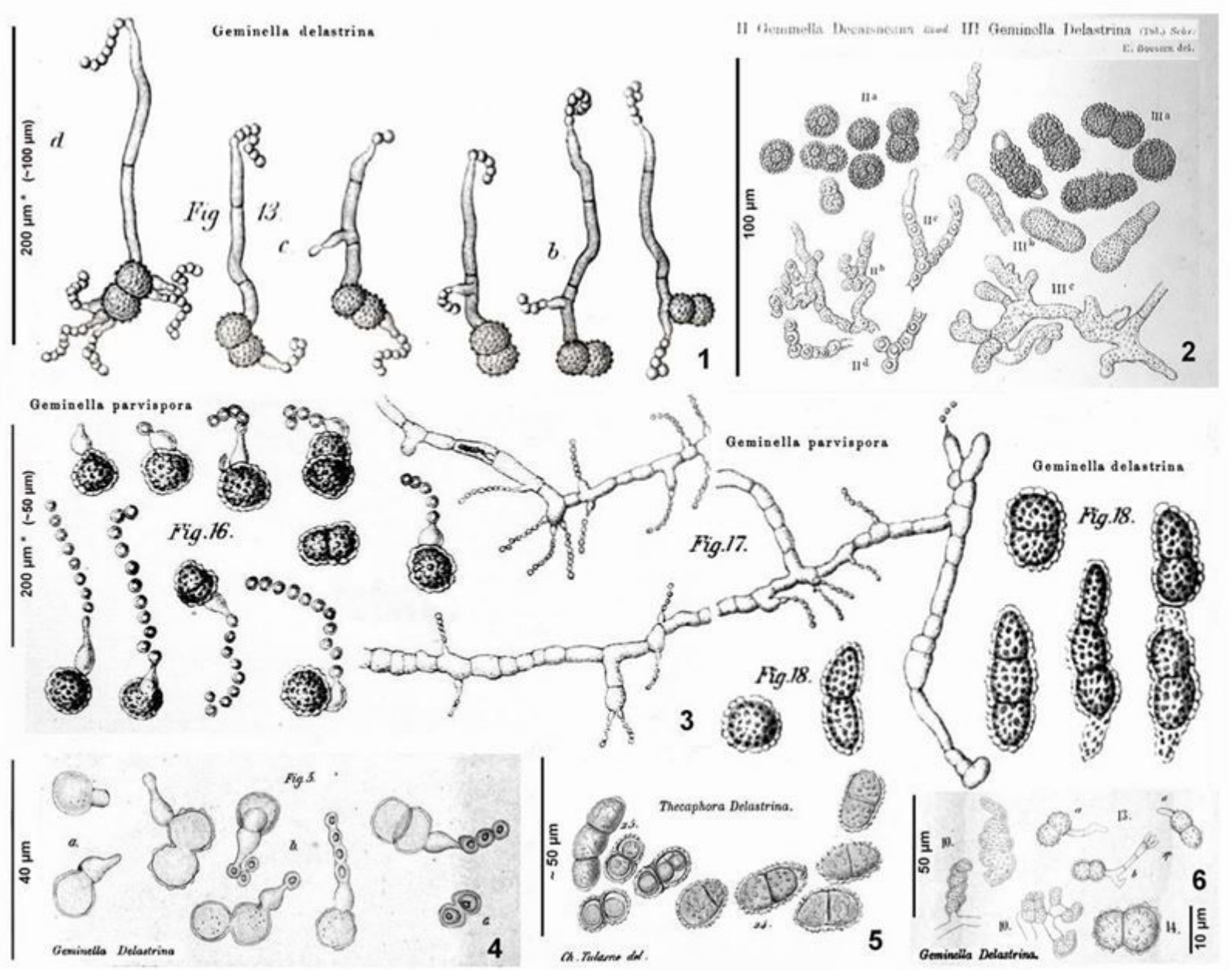

Figure 21

Chlamydospores and microconidial anamorphs in Schroeteria delastrina and S. decaisneana (= Geminella parvispora) as illustrated by different authors. 1, 3-4. chlamydospores germinating by hyphae producing phialides and microconidia; 2,6 . formation of chlamydospores from hyaline multi-branched, flexuous to helicoid hyphae. 1. BREFELD (1883: pl. XI fig. 13), 2. BOUDIER (1887: pl. XV figs II-III), 3. BREFELD (1912: pl. III figs 16-18), 4. SCHRÖTER (1877: pl. XI fig. 5), 5. TULASNE \& TULASNE (1847: pl. 4 figs 24-25), 6. WINTER (1876: pl. IV figs 10, 13, 14). All scales were evaluated from the original prints based on the indicated magnification factor. Scales in Brefeld's drawings (with asterisk) were considered by us to be erroneous: in 1. the scale should be around $100 \mu \mathrm{m}$ instead of $200 \mu \mathrm{m}$ and in 3. around $50 \mu \mathrm{m}$ instead of $200 \mu \mathrm{m}$ when compared with drawings of Boudier (2.) and others (see also Tabs 4-5).

\section{Supplementary Files}

This is a list of supplementary files associated with this preprint. Click to download.

- S1SchroeterialTS1000MLMEGA7.pdf

- S2SchroeteriaLSU1000MLMEGA7.pdf

- S3SclerotiniaceaelQTREEtopology.pdf 